\title{
Disturbances, prescribed fire, and invasion by exotic plants in a xeric mixed-oak and oak-pine dominated area of the Ridge and Valley in eastern West Virginia
}

Jonathan A. Pomp

West Virginia University

Follow this and additional works at: https://researchrepository.wvu.edu/etd

\section{Recommended Citation}

Pomp, Jonathan A., "Disturbances, prescribed fire, and invasion by exotic plants in a xeric mixed-oak and oak-pine dominated area of the Ridge and Valley in eastern West Virginia" (2008). Graduate Theses, Dissertations, and Problem Reports. 1941.

https://researchrepository.wvu.edu/etd/1941

This Thesis is protected by copyright and/or related rights. It has been brought to you by the The Research Repository @ WVU with permission from the rights-holder(s). You are free to use this Thesis in any way that is permitted by the copyright and related rights legislation that applies to your use. For other uses you must obtain permission from the rights-holder(s) directly, unless additional rights are indicated by a Creative Commons license in the record and/ or on the work itself. This Thesis has been accepted for inclusion in WVU Graduate Theses, Dissertations, and Problem Reports collection by an authorized administrator of The Research Repository @ WVU. For more information, please contact researchrepository@mail.wvu.edu. 
Disturbances, Prescribed Fire, and Invasion by Exotic Plants in a Xeric Mixed-oak and Oak-pine Dominated Area of the Ridge and Valley in Eastern West Virginia

\author{
Jonathan A. Pomp \\ Thesis submitted to the Davis College of Agriculture, Forestry, and \\ Consumer Sciences at West Virginia University \\ in partial fulfillment of the requirements for the degree of
}

\author{
Master of Science \\ in \\ Forestry
}

David W. McGill, Ph.D., Chair

James S. Rentch, Ph.D.

Thomas M. Schuler, Ph.D.

Division of Forestry and Natural Resources

Morgantown, WV

2008

Keywords: prescribed fire, exotic invasive species, dendrochronology, tree-ofheaven, bole scorch height, timed meander, Nonmetric Multidimensional Scaling (NMS) ordination 


\section{ABSTRACT \\ Disturbances, Prescribed Fire, and Invasion by Exotic Plants in a Xeric Mixed-oak and Oak-pine Dominated Area of the Ridge and Valley in Eastern West Virginia}

\section{Jonathan A. Pomp}

This document discusses three fire and exotic invasive plant related research studies that were conducted in an area of the Ridge and Valley dominated by xeric mixed-oak and oak-pine forest communities. The first study characterizes the timing, frequency, and magnitude of canopy disturbances in the study area by investigating demographic (age distributions), anatomical (growth increment patterns), and structural (diameter distributions) evidence. In addition to the general reconstructed disturbance history, the potential link between overstory tree-of-heaven (Ailanthus altissima (P. Mill.) Swingle) populations and prior forest management disturbances (i.e. harvesting) is investigated. This study indicates an uneven-aged structure resulting from multiple disturbances of varying intensities throughout the area. One study area-wide disturbance event was identified around the turn of the $20^{\text {th }}$ century. The majority of the areas where tree-ofheaven has ascended into the main canopy are either in harvested areas, or along roads. Native ground-layer vegetation around the main tree-of-heaven stems is in danger of being severely impacted by vegetative reproduction.

In the second study, the relationship between plot-level three-year post-fire bole scorch height, or stem-bark char, parameters (independent variables) and other fire intensity variables (litter consumption, thermocouple temperature, and sapling mortality) are investigated. This study indicates that neither overstory nor sapling bole scorch height variables are significantly related to thermocouple temperature measurements. The sum of the sapling scorch heights is significantly related to litter consumption, but only accounts for $11 \%$ of the variation. However, all bole scorch height variables are significantly related to sapling mortality one growing season after the fire. This further illustrates the usefulness of scorch height as an estimator of relative fire intensity.

The third study examines the effects of a prescribed fire on understory exotic invasive plants. In this study, several analytical methods were employed to determine if: (1) abundance and importance increased following the fire, (2) relative fire intensity played a role, and (3) environmental variables were related to populations. The results indicated that only one species, tree-of-heaven, showed significantly higher abundance and importance following the prescribed fire. The results also implied that moister areas, where understory species richness was higher and where relative fire intensity was lower, provided a favorable microsite for the exotic invasive species. Furthermore, environmental factors played more of a role than relative fire intensity in determining the probability of presence of exotic invasive plants in the understory. 


\section{ACKNOWLEDGMENTS}

Without the support of numerous individuals, this research would not have been possible. First and foremost, I would like to thank my advisor, Dr. Dave McGill, not only for giving me the opportunity to continue my education in forestry at West Virginia University, but also for his constant support and guidance over the last few years. I also sincerely thank the other "listed" members of my graduate committee, Dr. James Rentch and Dr. Thomas Schuler, for input, recommendations, and editorial comments which undoubtedly strengthened my research and writing. I cannot thank Dr. Rentch enough for acting as, what I would deem, a second advisor. The extensive help and courtesy he extended to me throughout my time spent as a graduate student will never be forgotten. I am also very grateful for the help provided by Dr. Cynthia Huebner, who is, for structural reasons, an "unlisted" committee member. Cindy is one of the nicest professional people that anyone could meet and she deserves countless thanks for the help she voluntarily provided. In addition to providing field training and identification of pressed plant samples, she gave useful insight at meetings that only someone of her expertise could. I must also express my gratitude to the botanical connoisseur William Grafton, who shared his expertise both during field inventory and identification of pressed samples.

I am also grateful to the United States Department of Agriculture Forest Service, North River Ranger District, Harrisonburg, VA, for their cooperation. Without the help of Elwood Burge, Steve Croy, Terry Slater, and Carter Fox, field data collection would not have been possible. I am also indebted to Michael Marsh for plot establishment and collection of the 2003 and 2004 data during his time spent working on his Master's thesis at West Virginia University. Thanks to Matt Cummons for enduring long, hot summer days and nights afield in Pendleton County, as well as data entry. Also, thanks to Steve Croy and Curtis Waggy for supplemental data. I also thank Mark Healy for the courtesy and help he provided in reviewing harvesting records and aerial photographs while visiting the North River Ranger District headquarters.

I would also like to thank all of the other forestry graduate students, especially those of room 339 Percival, for help with the small, but significant, issues that that tend to drive a graduate student crazy (formatting, statistics, etc.). The Forest Resources Management faculty, especially Professor Stuart Moss and Dr. John Brooks, also deserve a thank you for encouragement and priceless advice that not only helped me to succeed in graduate school, but will continue to help me be successful throughout my professional career. Last, but certainly not least, I would like specially thank my parents, Kenneth and Teresa Pomp for their continued love, support, and motivation. Without these things, not to mention their financial support, I would have likely given up a long time ago.

This research was supported by the Cooperative State Research Service, U.S. Department of Agriculture, under Project NO. WVA00422. 


\section{TABLE OF CONTENTS}

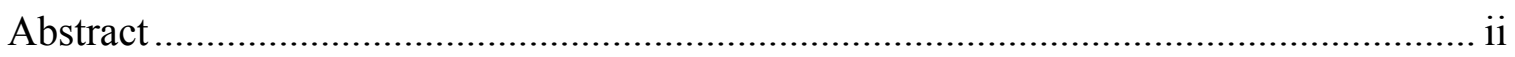

Acknowledgments.............................................................................................. ii

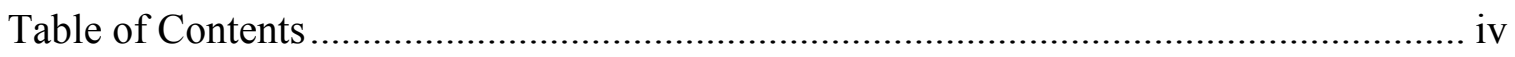

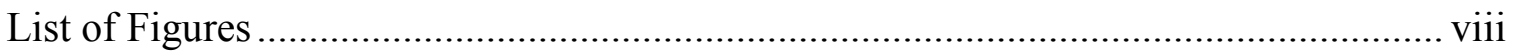

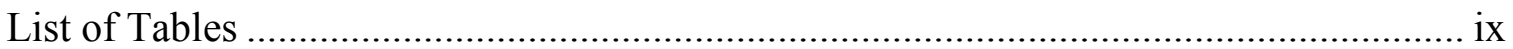

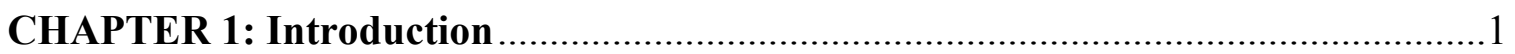

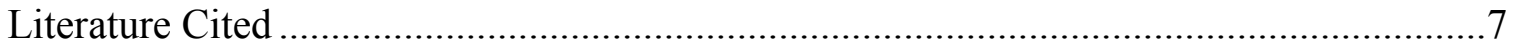

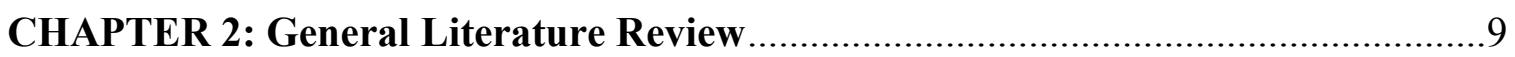

Exotic Invasive Species: Defined ............................................................................

Problems Imposed by Exotic Invasive Plant Species ………………………….............10

Important Exotic Invasive Plants in West Virginia and the Eastern US............................12

Xeric Mixed-oak and Oak-pine Forests of the Ridge and Valley .......................................17

Fire in Xeric Mixed-oak and Oak-pine Forests .............................................................18

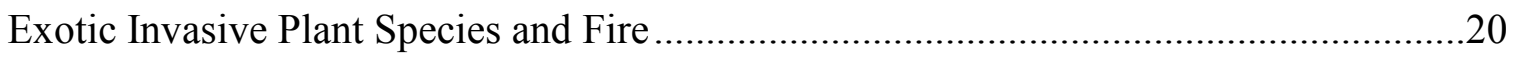

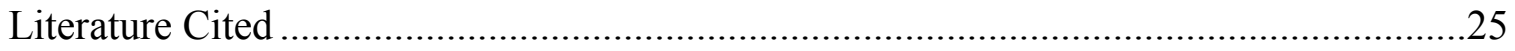

CHAPTER 3: Disturbance History and Ailanthus altissima (P. Mill) Swingle Establishment in a Xeric Mixed-oak and Oak-pine Dominated Area in the Ridge

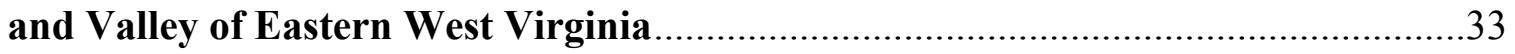

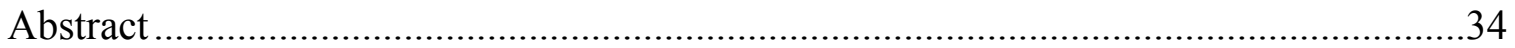

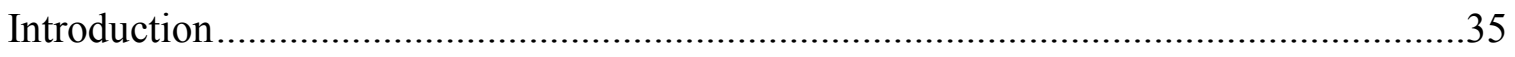

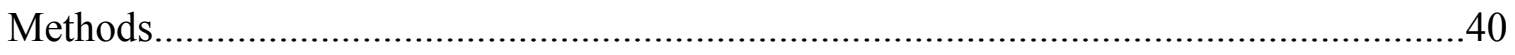

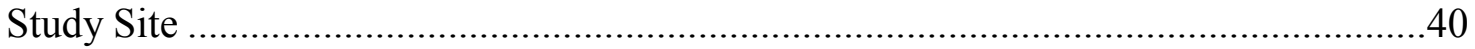

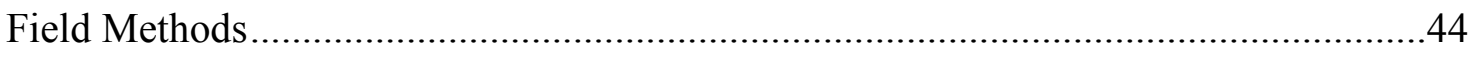

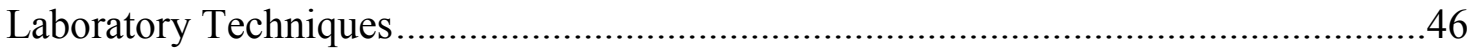

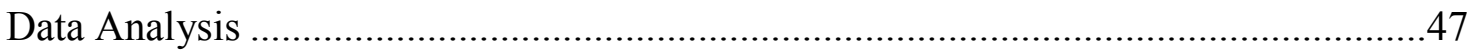

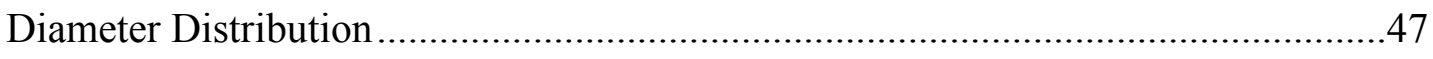

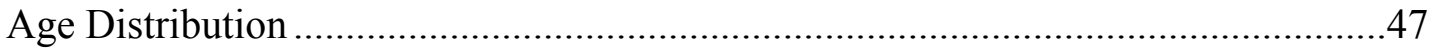


Growth Increment Patterns........................................................................4

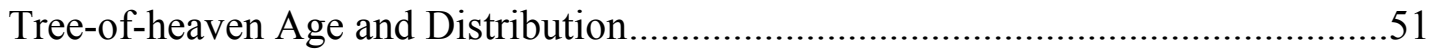

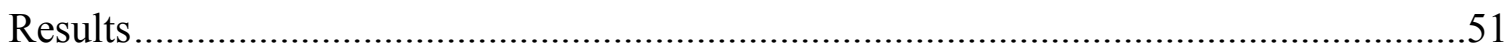

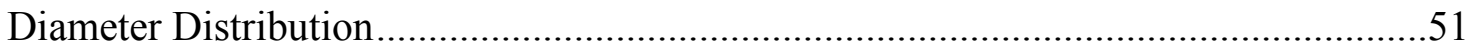

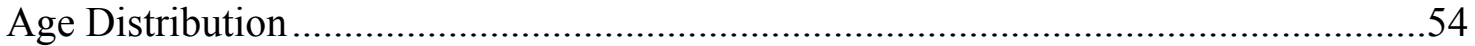

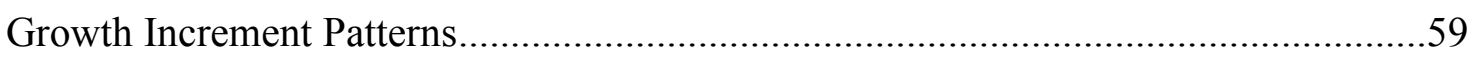

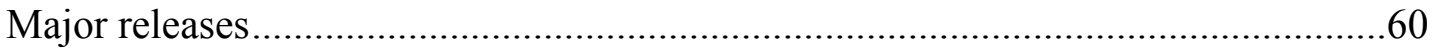

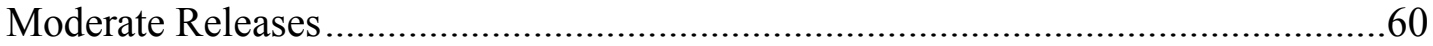

Small Releases........................................................................................61

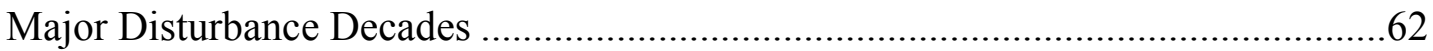

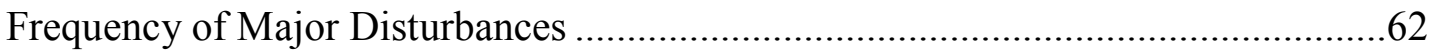

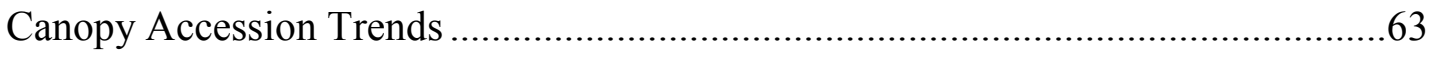

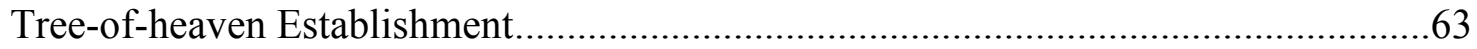

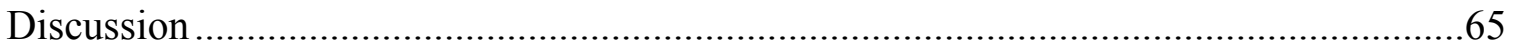

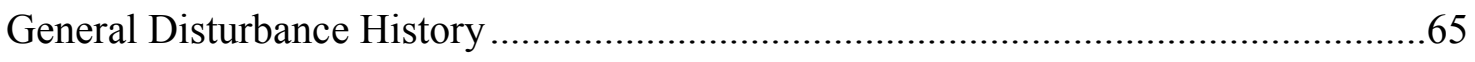

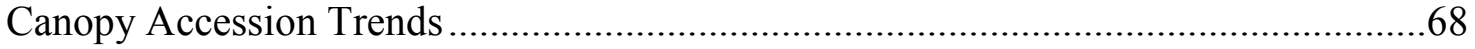

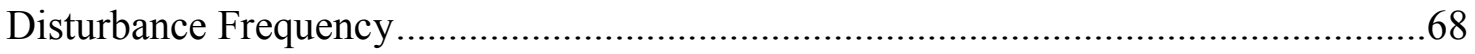

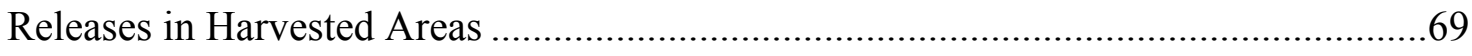

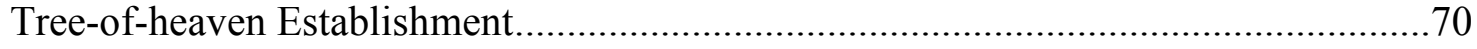

Conclusions and Management Implications ........................................................ 71

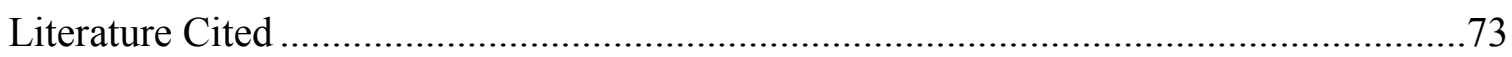

\section{CHAPTER 4: Investigating the Relationship between Bole Scorch Height and Fire} Intensity Variables in the Ridge and Valley Physiographic Province, West Virginia...

Abstract




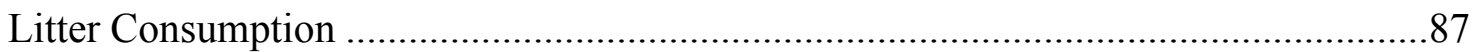

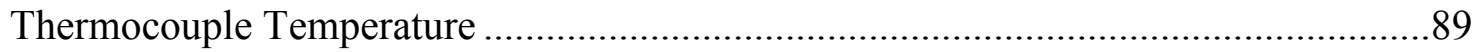

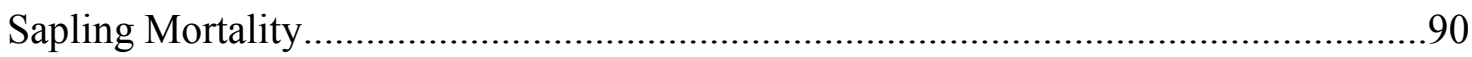

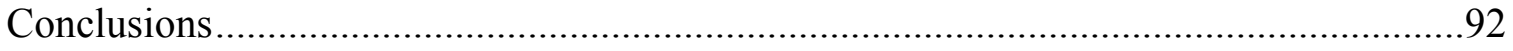

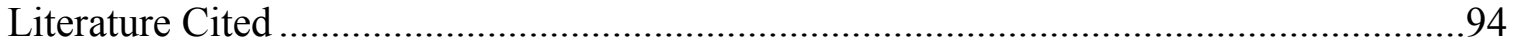

CHAPTER 5: Prescribed Fire and Invasion by Exotics in the Understory of a Xeric Appalachian Mixed-oak and Oak-pine Dominated Forest .........................................96

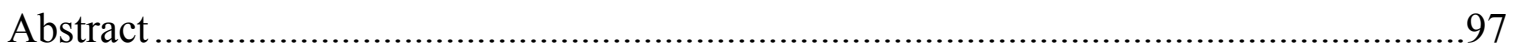

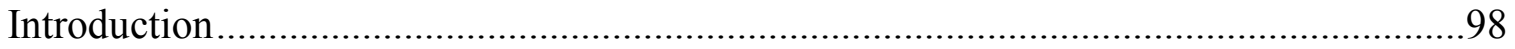

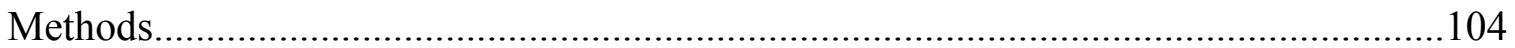

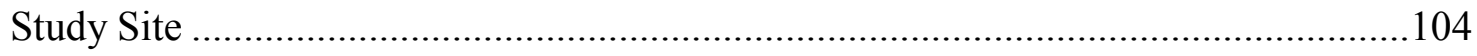

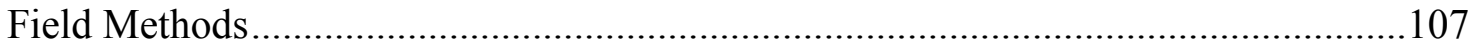

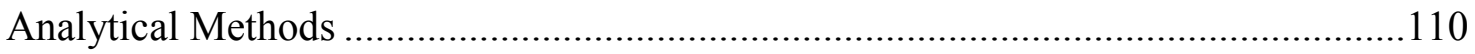

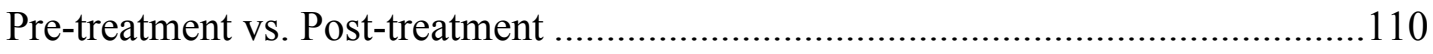

Exotic Invasive Plant Species and Relative Fire Intensity/Environmental Variables....

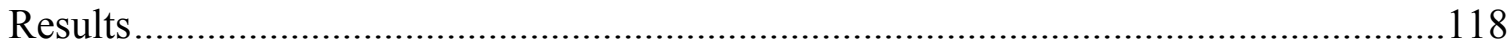

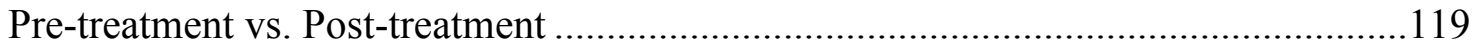

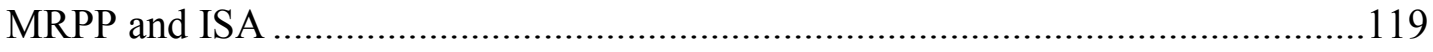

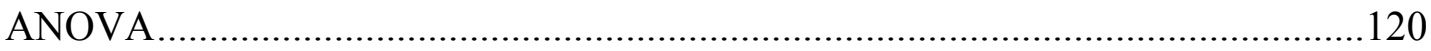

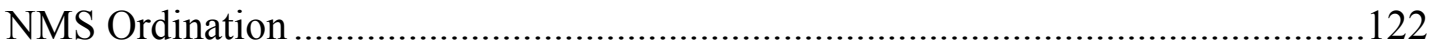

Exotic Invasive Plant Species and Relative Fire Intensity/Environmental Variables..126

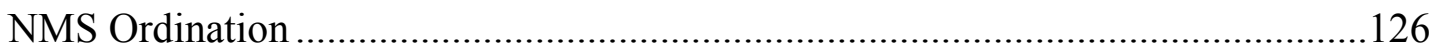

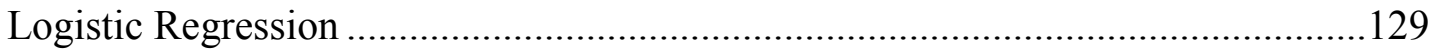

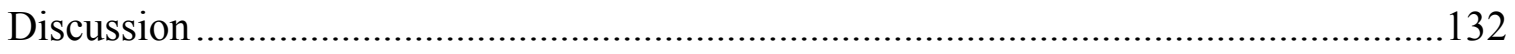

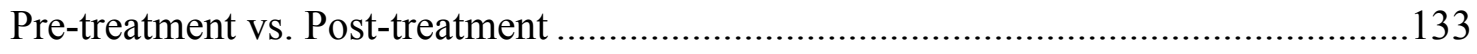

Exotic Invasive Plant Species and Relative Fire Intensity/Environmental Variables..136

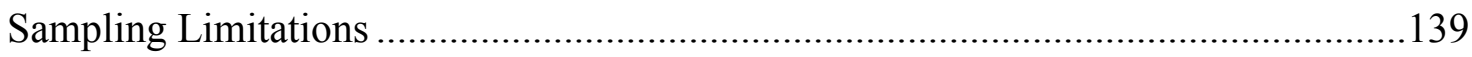

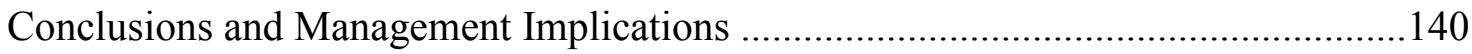

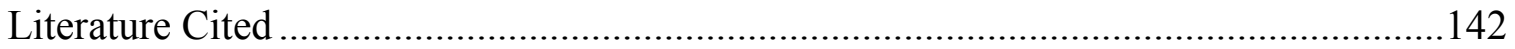




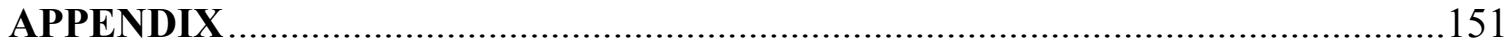

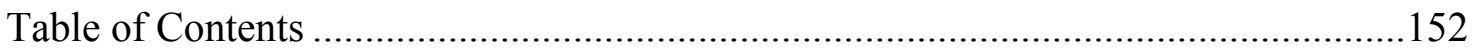




\section{LIST OF FIGURES}

Figure 3.1. Harvest areas on, and around the base of, Dunkle Knob

Figure 3.2. Abundant regeneration surrounding a co-dominant tree-of-heaven on Dunkle

Knob .46

Figure 3.3. PDSI $\mathrm{d}_{\text {diff }}$ chronology for the Dunkle Knob Area .......................................50

Figure 3.4. Diameter distributions for the three most abundant species: NEU ................52

Figure 3.5. Diameter distributions for the three most abundant species: NEL ................53

Figure 3.6. Diameter distributions for the three most abundant species: SWU...............53

Figure 3.7. Diameter distributions for the three most abundant species: SWL ...............54

Figure 3.8. A comparative compilation of age-diameter relations (top), average growth patterns (middle), and number of releases (bottom) in the NEU sampling area......

Figure 3.9. A comparative compilation of age-diameter relations (top), average growth patterns (middle), and number of releases (bottom) in the NEL sampling area ...............56

Figure 3.10. A comparative compilation of age-diameter relations (top), average growth patterns (middle), and number of releases (bottom) in the SWU sampling area ..............57

Figure 3.11. A comparative compilation of age-diameter relations (top), average growth patterns (middle), and number of releases (bottom) in the SWL sampling area ..............58

Figure 3.12. Establishment dates of the oldest tree in areas where tree-of-heaven has

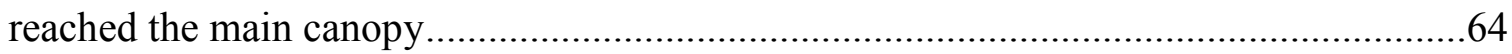

Figure 4.1. Area treated with prescribed fire by year on the GWNF ...........................80

Figure 4.2. The relationship between mean overstory scorch height $(\mathrm{cm})$ and sapling

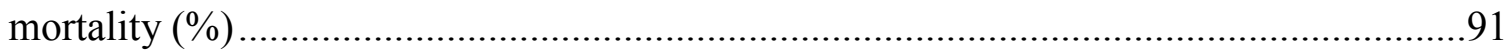

Figure 5.1. Harvest Areas on, and around the base of, Dunkle Knob ..........................106

Figure 5.2. Measurement plots at a sample point ................................................. 108

Figure 5.3. Average percent cover by species and measurement period .......................122

Figure 5.4. Average IV by species and measurement period .................................... 123

Figure 5.5. NMS ordination (axes 2 and 3) of sample plots (data are understory abundance (percent cover)) before and after the prescribed fire

Figure 5.6. NMS ordination (axes 1 and 2) of sample plots (data are "smoothed" understory presence/absence) after the prescribed fire. 


\section{LIST OF TABLES}

Table 3.1. Mean overstory composition values (IV $=0.5 *$ (relative density + relative basal area))

Table 3.2. Mean understory composition values $(\mathrm{IV}=0.5 *$ (relative density + relative

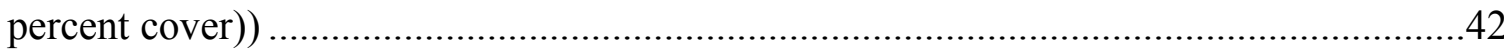

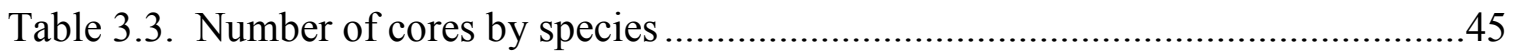

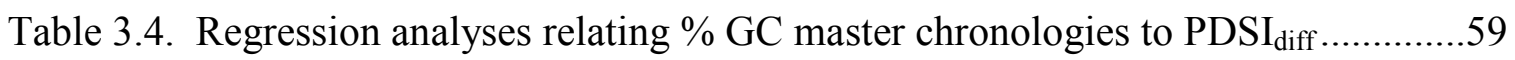

Table 3.5. Return intervals (years) for major disturbances........................................63

Table 4.1. Average scorch height parameters $(\mathrm{cm})$ by stratum ..................................87

Table 4.2. Relationships between bole scorch height variables $(\mathrm{cm})$ and litter

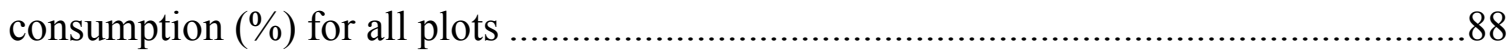

Table 4.3. Relationships between bole scorch height variables $(\mathrm{cm})$ and litter

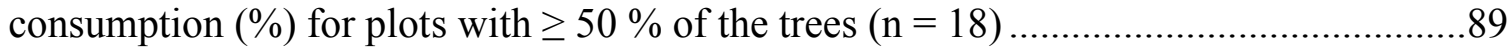

Table 4.4. Relationships between bole scorch height variables $(\mathrm{cm})$ and fire temperature

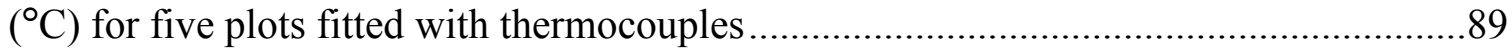

Table 4.5. Sapling mortality (\%) models and associated statistics ...............................91

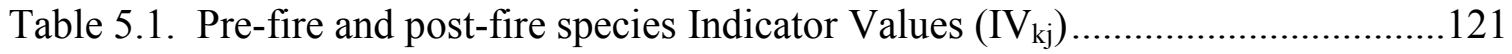

Table 5.2. Results of individual logistic runs for each statistically significant variable ......

Table 5.3. Results of multiple logistic regression models

Table 5.4. Interpretation of odds ratios 


\section{CHAPTER 1}

Introduction 
The vast majority of the dry hillsides of Ridge and Valley Physiographic Province of eastern West Virginia are encompassed by fire-associated oak (Quercus spp.) and pine (Pinus spp.) woodlands. The future of these forests are at risk due to the loss of recurring fires (Abrams 1992, Waldrop and others 2006) as well as other less frequent stand initiating disturbances. The species composition, in addition to the hot, dry climate, associated with the area, makes the Ridge and Valley especially suited for the reintroduction of fire to achieve management goals (Lafon and Grissino-Mayer In Press, Thomas-Van Gundy and others 2007). The use of prescribed fire to promote historical structure and composition in oak and oak-pine forests in this region is now steadily increasing, and has become a critically important management issue to the general public, as well as to foresters, biologists, ecologists, and other land and prescribed fire managers. Chapter 2 provides a complete literature review that details the uniqueness of the forested communities in this area and how fire historically played a role in their development.

Troublesome exotic invasive plants may also pose a significant threat to these communities (Mlot 2003, Williams 1998). In forested ecosystems, highly invasive exotic plant species such as tree-of-heaven (Ailanthus altissima (P. Mill.) Swingle), garlic mustard (Alliaria petiolata (Bieb.) Cavara \& Grande), and Japanese stilt grass (Microstegium vimineum (Trin.) A. Camus) may drastically inhibit successful establishment and development of native plants and lead to a decrease in regional biodiversity (D'Antonio and Vitousek 1992) and altered ecosystem processes (Vitousek and Walker 1989). Unfortunately, little is known about the relationship between prescribed fire and invasion by exotic invasive plants in these areas. The general 
literature review (Chapter 2) also details what exotic invasive plant species are, problems associated with them, and highlights species that are especially problematic in deciduous forests of West Virginia and the eastern United States (US).

Because invasive species have a tendency to invade disturbed sites, it is important to better understand the effects of prescribed fire (an anthropogenic disturbance) on this threat to forests of West Virginia. Increases in establishment and abundance of exotic invasives may have considerable negative impacts on native plant communities. If this is the case, many areas scheduled to be burned in the future may require exotic invasive monitoring or management prior to the application of prescribed fire. For example, exotic invasive plant pests could be controlled with herbicides prior to application of the fire treatment. Pre-fire control of invasive species would aim to make the forest more resilient to invasions, reduce the likelihood of post-fire establishment, and help protect native understories and regeneration of eastern oak and pine forest communities.

Following 81 years of fire exclusion, prescribed fire treatments were applied on March 29, 2004 to Dunkle Knob, a 314 ha area composed of xeric mixed-oak and oak-pine forest communities located on the North River Ranger District (formerly the Dry River Ranger District) of the George Washington National Forest (GWNF) in the Ridge and Valley $\left(38^{\circ} 37^{\prime} \mathrm{N}, 79^{\circ} 14^{\prime} \mathrm{W}\right)$. Thirty-six permanent circular 0.05 ha fixed area plots were established on the mountain in 2003 prior to the prescribed fire (Marsh 2005). Vegetation measurements were recorded in 2003 and 2004 on Dunkle Knob, as well as two adjacent areas, Brushy Knob and Heavener Mountain, to describe overstory, 
midstory, and understory strata, and to assess vegetation dynamics following prescribed fire using a "prescribed fire chronosequence" (Marsh 2005). Dunkle Knob was the only mountain where pre-fire data had been recorded. Initial vegetation measurements indicated the presence of some notable exotic invaders, including; tree-of-heaven, garlic mustard, Bell's honeysuckle (Lonicera X bella Zabel), and Canada bluegrass (Poa compressa L.). One of the conclusions of this early study was that neither percent cover or importance value of these exotic invasives changed significantly anywhere on Dunkle Knob immediately (three to four months) following prescribed fire (Marsh 2005).

However, understory communities are very dynamic and composition can change within a growing season, and from growing season to growing season following fire (Bowles and others 2007, Hutchinson 2006), as well as other disturbances (Small and McCarthy 2002).

Thanks to collaborative support from several people at West Virginia University (WVU) and the United States Department of Agriculture (USDA) Forest Service, the opportunity arose to sample the plots again during the 2007 growing season. The overall objective of the new project was to determine if post-fire levels of exotic invasive plant populations were greater than pre-fire levels. This question is answered in Chapter 5 by examining pre- and post-fire data using various proven statistical techniques, including: Multiresponse Permutation Procedures (MRPP), Nonmetric Multidimensional Scaling (NMS) ordination, and a single factor Analysis of Variance (ANOVA). Chapter 5 also examines exotic invasive plant population-environmental relationships. 
A secondary goal of this project was to characterize the timing, frequency, and magnitude of disturbances in the study area by investigating demographic (age distributions), anatomical (growth increment patterns), and structural (diameter distributions) evidence. In general, disturbance regime descriptions allow for an evaluation of recent theories about forest development and provide a better perception of community properties. The information presented in Chapter 3 should help foresters and other land managers to better understand how disturbance frequency, intensity, and severity might affect species composition and stand dynamics in xeric mixed-oak and oak-pine forests. In addition to the general reconstructed disturbance history, the potential link between overstory treeof-heaven populations and prior forest management disturbances (i.e. harvesting) is investigated. This analysis should show if harvesting played a role in tree-of-heaven establishment and distribution. Additionally, this analysis will provide GWNF managers with locations of tree-of-heaven infestation that may influence prescribed fire or other types of management and planning.

Another secondary goal of the project was to determine if fire intensity played a role in the distribution exotic invasive plants. Unfortunately, direct fire intensity measurements were restricted to five plots constrained in one area of Dunkle Knob. Therefore, in Chapter 4, I investigate the relationship between plot-level three-year post-fire bole scorch height, or stem-bark char, parameters (independent variables) and other fire intensity variables. Three relationships/predictions are evaluated: (1) litter consumption as a function of scorch height, (2) thermocouple estimated fire temperature as a function of scorch height, and (3) sapling mortality as a function of scorch height. The intent of 
this analysis was to evaluate whether these quick, simple, and inexpensive field measurements can help characterize prescribed fire behavior and its short-term effects on forest structure and composition. Significant surrogate fire intensity variables identified in Chapter 4 are related to exotic invasive plant populations in Chapter 5.

The information from this document should provide a better understanding of the interactions of disturbance, prescribed fire, and exotic invasive plant species over time, and across the landscape, in an area of the Ridge and Valley dominated by xeric mixed oak and oak-pine forest communities. These data will also provide insight to the future potential of troublesome exotic invasive plant species in the study area.

Chapters 3, 4, and 5 are formatted so that they can be easily adjusted for submittal for publication in a journal or as conference proceedings. Chapter 4 is already published as part of the proceedings of the $16^{\text {th }}$ Central Hardwood Forest Conference. 


\section{Literature Cited}

Abrams, M. D. 1992. Fire and the development of oak forests. Bioscience. 42(5): 346353.

Bowles, M. L.; Jacobs, K. A.; Mengler, J. L. 2007. Long-term changes in an oak forest's woody understory and herb layer with repeated burning. Journal of the Torrey Botanical Society. 134(2): 223-237.

D'Antonio, C. M.; Vitousek, P. M. 1992. Biological invasions by exotic grasses, the grass/fire cycle, and global change. Annual Review of Ecological Systems. 23: 63-87.

Hutchinson, T. 2006. Fire and the herbaceous layer of eastern oak forests In: Dickinson, Matthew B., ed. 2006. Fire in eastern oak forests: delivering science to land managers, proceedings of a conference. USDA Forest Service Gen. Tech. Rep. NRS-P-1.

Lafon, C. W.; Grissino-Mayer, H. D. In Press. Spatial patterns of fire occurrence in the central Appalachian Mountains and its implications for wildland fire management. Physical Geography.

Marsh, M. A. 2005. Floristic dynamics of Appalachian pine-oak forests over a prescribed fire chronosequence. Morgantown, WV: West Virginia University. 275p. M.S. Thesis.

Mlot, C. 2003. Invasive Species West Virginia. Cambridge, MA: Union of Concerned Scientists.

Small, C. J.; McCarthy, B. C. 2002. Spatial and temporal variation in the response of understory vegetation to disturbance in a central Appalachian oak forest. Journal of the Torrey Botanical Society. 129(2): 136-153.

Thomas-Van Gundy, M. T.; Nowacki, G. J.; Schuler, T. M. 2007. Rule-based mapping of fire adapted vegetation and fire regimes for the Monongahela National Forest. USDA Forest Service, Gen. Tech. Rep. NRS-12.

Vitousek, P. M.; Walker, L. R. 1989. Biological invasions by Myricacia faya in Hawaii: plant demography, nitrogen fixation, ecosystem effects. Ecological Monographs. 59: 247-265.

Waldrop, T. A.; Mohr, H. H.; Brose, P. H. 2006. Early dynamics of table mountain pine stands following stand-replacement prescribed fires of varying intensity. USDA Forest Service, Gen. Tech. Rep. SRS-92. 
Williams, C.E. 1998. History and status of table mountain pine-pitch pine forests of the southern Appalachian mountains (U.S.A.). Natural Areas Journal. 18: 81-90. 


\section{CHAPTER 2}

General Literature Review 


\section{Exotic Invasive Species: Defined}

Based on Executive Order 13112 of February 3, 1999, the definition of the term exotic invasive species can be broken into two parts, exotic and invasive. The term exotic, used synonymously with alien and non-native, refers to, with respect to a particular ecosystem, any species (plant, mammal, bird, fish, insect, aquatic invertebrate, or fungi) that is not native to that ecosystem. The term invasive refers to a species whose introduction does, or is likely to, cause economic or environmental harm, or harm to human health (Clinton 1999). Therefore an exotic invasive species is a species that is not native to a particular ecosystem, it is found in that particular ecosystem, and has, or is likely to impair economic and environmental benefits associated with that particular ecosystem, or cause human harm.

\section{Problems Imposed by Exotic Invasive Plant Species}

Invasions by alien plants are a growing challenge worldwide to the management of native biodiversity and ecosystem functioning (Brooks and others 2004, Gordon 1998, Mooney and Hobbs 2000, Steele and others 2006, Vitousek and others 1996). Exotic invasive plant species have been, and are currently, causing a wide variety of problems throughout the US. The environmental problems caused by exotic invasive plant species can include, but are not limited to: diminished land values (Higgins and others 1999), loss and destruction of forage and habitat for wildlife (Allan and others 1997, Steenkamp and Chown 1996), loss of forest understory productivity (McCarthy 1997, Stinson and others 2006), loss of available grazing land (Bangsund and Leistritz 1991), soil degradation (Ashton and others 2005, Vitousek and Walker 1989), and, in some cases, diminished 
recreational enjoyment (J. Pomp, personal observation). Exotic invasives can also hybridize with native species, resulting in negative genetic impacts (Mlot 2003). Furthermore, if exotic invasive plants become well established, they may alter forest fuel properties and impact fire behavior and fire regime characteristics (e.g. frequency, intensity, extent, type, and seasonality) (Brooks and others 2004, D'Antionio and Vitousek 1992, Mack and D'Antonio 1998). If these fire regime changes promote the dominance of the invaders, then an invasive plant-fire regime cycle can be established, making ecological restoration much more difficult (Brooks and others 2004). Given that the cumulative numbers of exotic invasive plant species in the forests of West Virginia may be increasing over time (Huebner 2003), few ecologists and conservation biologists will argue that the worst of the problems caused by these unwanted plant pests are behind us.

In West Virginia and throughout the mixed deciduous hardwood forests of the eastern US, invasive shrubs, vines, trees, and grasses are threatening native flora, as well as the habitats that they compose. Once established, highly invasive plants such as Japanese stilt grass, garlic mustard, and tree-of-heaven may be capable of crowding out important native vegetation in forests in only a few years time. Of particular importance, in West Virginia and throughout the central Appalachians, is the impact of exotic invasive plant species on forest reproduction and economically valuable herbaceous plant communities, e.g., American ginseng (Panax quinquefolius L.), goldenseal (Hydrastis canadensis L.), and black cohosh (Cimicifuga racemosa (L.) Nutt.). Exotic invasive plant species also pose a significant threat to threatened, endangered, or otherwise rare plant communities 
and species. A study by Flather and others (1994) ranked exotic invasive plant species as being one of the most important threats to endangered species, second only to habitat degradation/loss.

Management for control of exotic invasive plants often proves to be difficult and costly. Some exotic invasive species have caused major economic losses in forestry, agriculture, as well as other segments of the US economy. Pimental and others (2000) estimate the total annual costs (costs due to control measures, losses, and damages) of exotic invasive plants species to equal just over $\$ 34$ billion per year. Unfortunately, ample data on the economic impacts of exotic invasive plant species in West Virginia are not available.

\section{Important Exotic Invasive Plants in West Virginia and the Eastern US}

Despite there being a high number of exotic plant species found in West Virginia, the USDA's invasive and noxious weeds list for West Virginia lists only nine species. The WVDNR recognizes twelve plant species as being especially threatening to the health and productivity of West Virginia's native ecosystems. Only one of these species, multiflora rose (Rosa multiflora Thunb. ex Murr.), made the USDA's invasive and noxious weed list. Known as the "Dirty Dozen," the 12 most problematic of the exotic invasive plants in West Virginia include: crown vetch (Coronilla varia L.), garlic mustard, Japanese knotweed (Polygonum cuspidatum Sieb. \& Zucc.), Japanese stilt grass, kudzu (Pueraria montana (Lour.) Merr.), mile-a-minute weed (Polygonum perfoliatum L.), multiflora rose, purple loosestrife (Lythrum salicaria L.), reed canary grass (Phalaris 
arundinacea L.), tree-of-heaven, water shield (Brasenia schreberi J.F. Gmel.), and yellow iris (Iris pseudacoris L.) (Grafton 2007).

The USDA Forest Service lists five of these species (crown vetch, garlic mustard, Japanese knotweed, Japanese stilt grass, and purple loosestrife) as highly invasive in the eastern region of the US. These plants are all non-native, highly invasive plants which invade natural habitats and may have the ability to replace native species (USDA Forest Service, Eastern Region 1998). Despite being the exotic invasive that is most likely to be encountered in a forest in West Virginia (Huebner 2003), multiflora rose is only considered by the USDA Forest Service as moderately invasive (less invasive than the five aforementioned species) in the eastern region. They suggest that, if this species is significantly affecting native species, then it is doing so only in local areas (USDA Forest Service, Eastern Region, 1998). The 1998 USDA Forest Service list failed to categorize/list kudzu, mile-a-minute-weed, reed canary grass, water shield, and yellow iris. In their summary report of exotic invasive species in West Virginia, the Union of Concerned Scientists identified two of previously mentioned exotic invasive plants, Japanese stilt grass and purple loosestrife, as being particularly devastating to the ecological integrity if West Virginia's native ecosystems, as well as the economy (Mlot 2003).

Given their physiological traits, range, and habitat, garlic mustard, Japanese stilt grass, multiflora rose, and tree-of-heaven can be considered as some of the exotic invasive 
species that pose the greatest threats to forested ecosystems. Each of these species is introduced individually in the following paragraphs.

Garlic mustard, also commonly referred to as hedge-garlic, jack-by-the-hedge, poor-man's-mustard, jack-in-the-bush, and garlic root, is an overwintering herb of European descent (Nuzzo 2000). The exotic herb was first recorded in North America in 1868 on Long Island, New York, and has spread exponentially since its introduction (Nuzzo 1992, Nuzzo 1993). Garlic mustard can now be found in 34 states of the Union and four Canadian provinces (Nuzzo 2000). This herbaceous exotic invasive may have the ability to readily invade and dominate the understories of forests throughout the eastern US and adjacent Canada (Nuzzo 1993). Like the majority of exotic invasive species, disturbance favors the establishment, spread, and growth of garlic mustard. In general, the species can easily become established and invade forests that have experienced multiple disturbances that decrease stand quality (e.g. diameter limit harvests) (Byers and Quinn 1998, Nuzzo 1991). However, a study by Nuzzo (1999) showed that, even in "high quality" forests (relatively undisturbed), after invasion, garlic mustard spreads annually and becomes a permanent part of the community, increasing in presence, but fluctuating in cover and density.

Japanese stilt grass, also commonly referred to as stilt grass, annual jewgrass, wire grass, Nepalese browntop, and Chinese packing grass, is a shade tolerant $\mathrm{C}_{4}$ annual grass of Asiatic origin. The exotic grass was introduced into the US in 1919 in Knoxville, Tennessee (Fairbrothers and Gray 1972). Placed in an environment with no natural 
enemies, the aggressive grass readily reproduced and began to disseminate. Today, it is widely distributed in dense patches on river banks, flood plains, damp fields, swamps, lawns, woodland thickets, logging roads, and roadsides throughout the eastern US (Barden 1987, Cole and Weltzin 2005, Fairbrothers and Gray 1972). Some feel that Japanese stilt grass should be considered the greatest threat to native understory habitats of West Virginia's forests.

Japanese stilt grass possesses several traits that contribute to its invasive nature. The grass shows a very plastic response to varying habitat conditions (Claridge and Franklin 2002, Gibson and others 2002, Tu 2000, Winter and others 1992). For example, Japanese stilt grass, like all $\mathrm{C}_{4}$ plants, prefers moderate to high light levels for reproduction, dispersal, and establishment, however, Japanese stilt grass can grow, reproduce, and disperse seed in only five percent full sunlight (Winter and others 1992). Japanese stilt grass has also been reported to promote positive feedback processes with the soil, further enhancing its ability to spread (Gibson and others 2002, Kourtev and others 1998, Tu 2000). The exotic invasive grass also possesses a persistent seed bank that remains viable for three to seven years (Barden 1987, Gibson et 2002, Tu 2000). Japanese stilt grass is slow to invade undisturbed areas; however, disturbance (natural or anthropogenic) favors the establishment of the species (Barden 1987, Oswalt and others 2007, Tu 2000). In West Virginia, Japanese stilt grass populations are especially abundant on logging roads and forest edges following operations that disturb the soil or forest canopy. 
Multiflora rose, also known as rambler rose, is a perennial shrub of Asian descent. The exotic invasive was originally introduced to the eastern US from Japan in 1886 for use as an understock for ornamental roses (Eckardt 1986, Wyman 1949). The US government, specifically the Soil Conservation Service (SCS) (currently the Natural Resources Conservation Service (NRCS)), promoted the use of the plant. In the early $20^{\text {th }}$ century the SCS conducted several tests and decided that multiflora rose was the best species to replace osage orange (Maclura pomifera (Raf.) Schneid.) as livestock barriers, or "fences", between prairies and farms (Steavenson 1946). The problematic shrub would soon escape urban areas and fields where it was planted and readily invade various types of areas. Multiflora rose is now found in 31 of the 50 states in the US, primarily in the eastern region (Swearingen 2008). The shrub can successfully invade pastures and other unplowed lands, crowding out existing vegetation and creating dense, impenetrable thickets (Eckardt 1986). Problems associated with multiflora rose, however, are not restricted to these areas. The exotic invasive shrub can endure a wide range of edaphic and environmental conditions (Steavenson 1946) and can often be found in forested ecosystems in West Virginia, and throughout the eastern US, impairing native understory and shrub vegetation layers. A study by Huebner (2003) showed that multiflora rose was associated with forested counties in West Virginia. Her study was indicative of the potential threat multiflora rose can present to oak dominated forests in West Virginia.

Tree-of-heaven, also commonly referred to as ailanthus, Chinese sumac, and varnish tree, is a fast growing, exploitive tree of Asiatic origin. The highly invasive exotic tree-ofheaven is one of the most problematic exotic invasive species in the Appalachians and 
throughout the US. Tree-of-heaven may have the ability to drastically inhibit successful establishment and development of native plants and lead to a decrease in regional biodiversity (D’Antonio and Vitousek 1992) and altered ecosystem processes (Vitousek and Walker 1989). The exotic tree was introduced into the US by William Hamilton, a Philadelphia gardener and plant collector, in 1784 (Hu 1979, Shah 1997). Tree-ofheaven may have also been introduced into the western US in the 1800's by Chinese miners as they settled in California to seek gold (Hoshovsky 1988). The exotic invasive tree is now found in $60 \%$ of the states (Swearingen 2008). Tree-of-heaven can be found threatening thousands of acres of native flora in 38 of the 55 counties of West Virginia (69\%) (Harmon and others 2006). It has become well established in several of these counties primarily around urban areas and in disturbed areas of forests. Especially problematic, almost pure, stands of tree-of-heaven can be found in the eastern panhandle (D. McGill, Forest Resources Extension Specialist, WVU Division of Forestry and Natural Resources, personal communication).

\section{Xeric Mixed-Oak and Oak-Pine Forests of the Ridge and Valley}

The Ridge and Valley Physiographic Province of eastern West Virginia is characterized by its rugged and heterogeneous topography composed of dry slopes. Highly infertile sites that are inhospitable to mesophytic hardwood species are common throughout the area. The hot, dry hillsides in this area support xeric mixed-oak and oak-pine woodlands. The most common species found in these wooded communities include, chestnut oak (Quercus prinus L.), scarlet oak (Quercus coccinea Muenchh.), table mountain pine (Pinus pungens Lamb.), pitch pine (Pinus rigida P. Mill.), and Virginia pine (Pinus 
virginiana $\mathrm{P}$. Mill). These species possess certain silvical characteristics that allow for colonization and persistence on poor sites. All of the species, except chestnut oak, are classified as shade intolerant (Hicks 1998, Williams \& Johnson 1990). Chestnut oak is classified as intermediate in shade tolerance (Hicks 1998). All of the species have site adaptive root strategies as well (i.e. they tailor the physiologic processes in their roots to allow for the greatest survival and growth on a given site). For example, the pines possess the ability to root in underdeveloped soil and rock crevices (Williams \& Johnson 1990), while the oaks have superior root systems and a high root to shoot ratio. Other than scarlet oak, the species found in these forests are resistant to injuries from fire (Hicks 1998). Both the pines and the oaks have thick bark and the latter posses a superb ability to compartmentalize injury (Smith and Sutherland 1999). Also, table-mountain pine and pitch pine possess serotinous cones (Williams \& Johnson 1990).

\section{Fire in Xeric Mixed-Oak and Oak-Pine Forests}

Historically, fire has played a key role in maintaining forest composition in pine-oak and mixed-oak forests in West Virginia and throughout the Appalachians (Abrams 1992, Brose and others 2001, Schuler and McClain 2003, Sutherland and others 1995). Before fire suppression became a policy in the eastern US between the late 1920s and 1950s, these forests were shaped by a combination of large scale disturbances (e.g. drought, stand-replacing wildfire, hurricane, and insect or disease outbreak) and low-intensity fires. Sutherland and others (1995) estimated that major fires occurred about every 10 to 15 years in table mountain pine stands in southwestern Virginia. Both Brose and Waldrop (2006b) and Yarnell (1998) estimated that prior to the fire suppression era, stand 
level disturbances in the southern Appalachians occurred once every 6 to 13 years. Rentch and Hicks (2003) found that large canopy disturbances involving multiple trees occurred every 17 years in oak dominated old-growth stands in the Central Hardwoods Region.

These types of disturbances formed stands of mixed-oak and pine, and more frequent low-intensity fires maintained this composition (Abrams 1992, Brose and others 2001). Several studies have estimated low intensity fire return intervals in these forests. These return intervals are comparable to those of stand-level disturbances. Sutherland and other (1995) estimated that low-intensity fires occurred every 9 to 11 years. Harmon (1982) found that periodic fires occurred, on average, about every 12 years in the Great Smoky Mountains. Shumway and others (2001) calculated fire-return intervals of 8 years in an oak forest in western Maryland. Schuler and McClain (2003) reported fire-return intervals of 7 to 15 years from 1895 to 2002 in an oak forest in the Ridge and Valley Physiographic Province of eastern West Virginia. Weibull median fire return intervals of 4 to 8 years occurred in rimrock oak-pine communities at the New River Gorge National River in West Virginia (Maxwell 2006).

The diminution of fire as a disturbance agent, and the associated change in structure and species composition, has led to a decline of both oak and, especially, pine communities in some areas (Abrams 1992, Brose and Waldrop 2006a). Continued absence of fire in oakpine communities could soon lead to a decline in pine species, and eventual oak dominance (Abrams 1992, Sutherland and other 1995). Table mountain and pitch pine 
dominated communities, in particular, are recognized by the Southern Appalachian Man and the Biosphere (SAMAB), a program that encourages the utilization of ecosystem and adaptive management principles, as one of 31 rare communities (SAMAB 1996). Researchers once thought that, without stand initiating fires, successful regeneration of table mountain and pitch pine communities could not occur (Brose and others 2002, Sutherland and others 1995, Williams and Johnson 1990). Recent research, however, suggests that repeated low intensity fires can achieve successful table mountain pine regeneration (Waldrop and others 2006). Successful management of mixed-oak and oakpine forests, without restoration of historical fire regimes, is difficult (Abrams 1992, Barden \& Woods 1976, Marsh 2005, Sutherland and others 1995, Welch and others 2000, Williams \& Johnson 1990). This information has spurred land managers to increase the number and extent of prescribed fires in these forest ecosystems in efforts to restore them to their historical structure and to promote regeneration of native oak and pine species. This increase in prescribed fire is carried out primarily on federal lands (Elliot and others 1999, Lafon and others 2005). In addition to the management resulting from altered disturbance and fire regimes, the future of these ecologically important forests are likely to be negatively affected by exotic invasive plants (Mlot 2003, Williams 1998).

\section{Exotic Invasive Plant Species and Fire}

In addition to encouraging historical forest structure and enhancing tree regeneration, natural and prescribed fire has also been shown to indirectly promote increases in both richness and cover of native herbaceous plants in forest understory communities (Bowles 
and others 2007, Hutchinson 2006, Nuzzo and others 1996). These increases allow for greater diversity and, in general, a better habitat for local fauna. However, fire and other disturbances (i.e. thinning/harvesting and herbicide treatments) that decrease canopy cover and increase understory light, may also promote invasion by exotic plant species (Bossard 1991, D'Antonio 1993, Hobbs and Huenneke 1992, Hutchinson and others 2004, Larson 2003, Mooney and Hobbs 2000, Pyle 1995, Stapanian and others 1998).

The relationship between fire and invasion by exotic plants is not well understood. A few studies have directly examined this relationship in different forested ecosystems. The results, however, are variable and in some cases, contradictory. Some have found that fire, natural or anthropogenic, promoted exotic invasive plant populations. Others have found little to no change or negative responses by exotic invasives. For instance, Bridgewater and Backshall (1981) found that natural fire enhanced exotic invasive forbs and grasses in Eucalyptus woodlands of Western Australia. Hester and Hobbs's (1992) results contradicted those of Bridgewater and Backshall (1981). They reported decreases in the density of exotic invasive forbs and grasses in Eucalyptus woodlands in the same region. Wein and others (1992) found that exotic annuals and biennials invaded recently burned areas of Wood Buffalo National Park in Canada. In ponderosa pine (Pinus ponderosa P. \& C. Lawson) forests of the western US, fire has been shown to increase both the richness and abundance of exotic invasive species (Crawford and others 2001, Griffis and others 2001). Both of these studies showed that exotic invasive species were far more abundant where fire severity, or intensity, was highest. Laughlin and others (2004), on the other hand, found little to no change in exotic invasive plant populations 
following wildfire in old-growth ponderosa pine forests located in Grand Canyon National Park in Arizona. In other areas of the western US, like the California coast, interior valleys, and other western grassland and prairie ecosystems, fire is used as a management tool to control exotic invasives and promote native vegetation (Rice 2005).

Studies in the eastern US showed similar variability in the effects of fire on exotic invasive plant populations. Bowles and others (2007) showed that seventeen years of repeated annual low intensity burning promoted garlic mustard abundance in an Illinois oak forest. In their study, garlic mustard persisted and showed greater abundance in burned areas relative to unburned areas. Contrary to Bowles and others (2007) findings, Nuzzo and others (1996) found that repeated annual burnings facilitated a reduced abundance of garlic mustard in a sand forest in Illinois. Nuzzo 1991 reported that garlic mustard showed no decline with low intensity fire and some decline with mid-intensity fire. Glasgow and Matlack (2006) found that prescribed burning and canopy-opening management practices facilitated invasion by Japanese stilt grass and multiflora rose in a mixed deciduous forest of Ohio. Doren and Whiteaker (1990) reported little to no change in the populations of the exotic invasive Brazilian pepper tree (Schinus terebinthifolius Raddi) in Florida woodlands following fire. Based on the available literature, the variable population responses of exotic invasive plant to fire appear to be due to both regional and local landscape variation (biology, different climates and microsites, etc.), and to be both site and species specific. That is, it is highly likely that responses to fire will be different in dissimilar areas or between disparate species on the same site. 
Direct assessments of the relationship between fire and exotic invasive plant populations in forested ecosystems are limited to the abovementioned studies. Furthermore, no documented studies have explored this relationship in West Virginia. Perhaps more importantly, it has not been examined in forests of the Ridge and Valley Physiographic Province, an area that because of its unique species composition and climate is especially suited for the reintroduction of fire to achieve management goals (Thomas-Van Gundy and others 2007, Lafon and Grissino-Mayer In Press). The use of prescribed fire in oak and oak-pine forests in this region is steadily increasing, especially on the GWNF, and has become a critically important management issue to the general public, as well as to foresters, biologists, ecologists, and other land and prescribed fire managers. GWNF lands experienced an astounding 2,240 \% increase in area prescribed burned from the 1980 s to the 1990 s, and a $140 \%$ increase from the 1990 s to the 2000 s, respectively.

The very hot, dry hillsides in this area provide ecologically unique ecosystems whose futures are at risk, not only due to altered fire regimes, but also due to invasion by exotic plants. Little is known about the relationship between prescribed fire and invasions by exotic invasive plants in these areas, hence, as the use of fire as a management tool increases, exotic invasives could be a major threat to future forest composition. Increases in establishment and abundance of exotic invasives may have severe negative impacts on native plant communities. If this is the case, many areas scheduled to be burned in the future may require exotic invasive monitoring or management prior to the application of prescribed fire. For example, exotic invasive plant pests could be controlled with herbicides, or other means, prior to application of the fire treatment. Pre-fire control of 
invasive species would aim to make the forest more resilient to invasions, reduce the likelihood of post-fire establishment, and help protect native understories and the future of eastern oak and oak-pine forests. 


\section{Literature Cited}

Abrams, M. D. 1992. Fire and the development of oak forests. Bioscience. 42(5): 346353.

Allan, D. G.; Harrison, J. A.; Navarro, R. A. [and others]. 1997. The impact of commercial afforestation on bird populations in Mpumalanga province, South Africa: insights form bird-atlas data. Biological Conservation. 79: 173-185.

Ashton, I. W.; Hyatt, L. A.; Howe, K. M. [and others]. 2005. Invasive species accelerate decomposition and litter nitrogen loss in a mixed deciduous forest. Ecological Applications. 15(4): 1262-1272.

Bangsund, D. A.; Leistritz, F. L. 1991. Economic impact of leafy spurge in Montana, South Dakota, and Wyoming. Agriculture Economics Report No. 275. North Dakota State University, Fargo.

Barden, L. S. 1987. Invasion of Microstegium vimineum (Poaceae), an exotic, annual, shade-tolerant, C4 grass, into a North Carolina floodplain. American Midland Naturalist. 118(1): 40-45.

Barden, L. S.; Woods, F. W. 1976. Effects of fire on pine and pine hardwood forests in the southern Appalachians. Forest Science. 22(4): 399-403.

Bossard, C. C. 1991. The role of habitat disturbance, seed predation, and ant dispersal on establishment of the exotic shrub Cytisus scoparius in California. American Midland Naturalist. 126(1): 1-13.

Bowles, M. L.; Jacobs, K. A.; Mengler, J. L. 2007. Long-term changes in an oak forest's woody understory and herb layer with repeated burning. Journal of the Torrey Botanical Society. 134(2): 223-237.

Bridgewater, P. B.; Backshall, D. J. 1981. Dynamics of some Western Australian ligneous formations with special reference to the invasion of exotic species. Vegetatio. 46: 141-148.

Brooks, M. L.; D’Antonio, D. M.; Richardson, D. M. [and others]. 2004. Effects of invasive alien plants on fire regimes. BioScience. 54(7): 677-688.

Brose, P. H.; Schuler, T. M.; Van Lear, D; Berst, J. 2001. Bringing fire back: the changing regimes of the Appalachian mixed-oak forests. Journal of Forestry. 99(11): 30-35.

Brose, P. H.; Tainter, F.; Waldrop, T. A. 2002. Regeneration history of three table mountain pine/pitch pine stands in northern Georgia. USDA Forest Service, Gen. Tech. Rep. SRS-48. 
Brose, P. H.; Waldrop, T. A. 2006a. Fire and the origin of table mountain pine - pitch pine communities in the southern Appalachian Mountains, USA. Canadian Journal of Forest Research. 36: 710-718.

Brose, P. H.; Waldrop, T. A. 2006b. Changes in the disturbance regime of upland yellow pine stands in the southern Appalachian Mountains during the $20^{\text {th }}$ century. USDA Forest Service, Gen. Tech. Rep. SRS-92.

Byers, D. L.; Quinn, J. A. 1998. Demographic variation in Alliaria petiolata (Brassicaceae) in four contrasting habitats. Journal of the Torrey Botanical Society. 125(2): 138-149.

Claridge, K.; Franklin, S. B. 2002. Compensation and plasticity in an invasive plant species. Biological Invasions. 4: 339-347.

Clinton, W. J. 1999. Executive Order 13112: Invasive Species. Federal Register. 64(25): 6183-6186.

Cole, P. G.; Weltzin, J. F. 2005. Light limitation creates patchy distribution of an invasive grass in eastern deciduous forests. Biological invasions. 7: 477-488.

Crawford, J. A.; Wahren, C.-H. A.; Kyle, S.; Moir, W. H. 2001. Responses of exotic plant species to fires in Pinus ponderosa forests in northern Arizona. Journal of Vegetation Science. 12: 261-268.

D’Antonio, C. M. 1993. Mechanisms controlling invasion of coastal plant communities by the alien succulent Carpobrotus edulis. Ecology. 74: 83-95.

D’Antonio, C. M.; Vitousek, P. M. 1992. Biological invasions by exotic grasses, the grass/fire cycle, and global change. Annual Review of Ecological Systems. 23: 63-87.

Doren, R. F.; Whiteaker, L. D. 1990. Effects of fire on different size individuals of Schinus terebinthifolius. Natural Areas Journal. 10(3): 107-113.

Eckardt, N. 1986. Element Stewardship Abstract for Rosa multiflora. Arlington: The Nature Conservancy. 8 p.

Elliot, K. J.; Hendrick, R. L.; Major, A.E. 1999. Vegetation dynamics after a prescribed fire in the southern Appalachians. Forest Ecology and Management. 114: 199213.

Fairbrothers, D. E.; Gray, J. R. 1972. Microstegium vimineum (Trin.) A. Camus (Gramineae) in the United States. Bulletin of the Torrey Botanical Club. 99 (2): 97-100. 
Flather, C. H.; Joyce, L. A.; Bloomgarden, C. A. 1994. Species endangerment patterns in the United States. USDA Forest Service, Gen. Tech. Rep. RM-241.

Gibson, D. J.; Spyreas, G.; Benedict, J. 2002. Life history of Microstegium vimineum (Poaceae), an invasive grass in southern Illinois. Journal of the Torrey Botanical Society. 129(3): 207-219.

Glasgow, L. S.; Matlack, G. R. 2007. The effects of prescribed burning and canopy openness on establishment of two non-native plant species in a deciduous forest, southeast, Ohio, USA. Forest Ecology and Management. 238: 319-329.

Gordon, D. R. 1998. Effects of invasive, non-indigenous plant species on ecosystem processes: lessons from Florida. Ecological Applications. 8: 975-989.

Grafton, E. 2007. Dirty dozen-West Virginia top invasive plants. 1 p. http://www.wvdnr.gov/Wildlife/DirtyDozen.shtm. [Date accessed: January 23, 2008].

Griffis, K. L.; Crawford, J. A.; Wagner, M. R.; Moir, W. H. 2001. Understory response to management treatments in northern Arizona ponderosa pine forests. Forest Ecology and Management. 146: 239-245.

Harmon, M. E. 1982. Fire history of the westernmost portion of Great Smoky Mountains National Park. Bulletin of the Torrey Botanical Club. 109: 74-79.

Harmon, P. J.; Ford-Werntz, D.; Grafton, W. 2006. Checklist and Atlas of the Vascular Flora of West Virginia. West Virginia Division of Natural Resources, Wildlife Resources Section, Elkins, WV. 381 p.

Hester, A. J.; Hobbs, R. J. 1992. Influence of fire and soil nutrients on native and nonnative annuals at remnant vegetation edges in the Western Australian Wheatbelt. Journal of Vegetation Science. 3(1): 101-108.

Hicks, R. R., Jr. (1998). Ecology and Management of Central Hardwood Forests. New York, NY: John Wiley \& Sons, Inc.

Higgins, S. I.; Richardson, D. M.; Cowling, R. M.; Trinder-Smith, D. H. 1999. Predicting the landscape-scale distribution of alien plants and their threat to plant diversity. Conservation Biology. 13(2): 303-313.

Hobbs, R. J.; Huenneke, L. F. 1992. Disturbance, diversity, and invasion: implications for conservation. Conservation Biology. 6(3): 324-337.

Hoshovsky, M. C. 1988. Element Stewardship Abstract for Ailanthus altissima. Arlington: The Nature Conservancy. 13 p. 
Hu, S. Y. 1979. Ailanthus. Arnoldia. 39(2): 29-50.

Huebner, C. D. 2003. Vulnerability of oak-dominated forests in West Virginia to invasive exotic plants: temporal and spatial patterns of nine exotic species using herbarium records and land classification data. Castanea. 68(1): 1-14.

Hutchinson, T. 2006. Fire and the herbaceous layer of eastern oak forests In: Dickinson, M. B., ed. 2006. Fire in eastern oak forests: delivering science to land managers, proceedings of a conference. USDA Forest Service Gen. Tech. Rep. NRS-P-1.

Hutchinson, T. F.; Rebbeck, J.; Long, R. 2004. Abundant establishment of Ailanthus altissima (tree-of-heaven) after restoration treatments in an upland oak forest. In: Yaussy, D. A.; Hix, D. M.; Long, R. P.; Goebel, C. P., eds. Proceedings of the $14^{\text {th }}$ Central Hardwoods Forest Conference. USDA Forest Service, Gen. Tech. Rep. NE-316.

Kourtev, P. S.; Ehrenfeld, J. G.; Huang, W. Z. 1998. Effects of exotic plant species on soil properties in hardwood forests of New Jersey. Water, Air, and Soil Pollution. 105: 493-501.

Lafon, C. W.; Grissino-Mayer, H. D. In Press. Spatial patterns of fire occurrence in the central Appalachian Mountains and its implications for wildland fire management. Physical Geography.

Lafon, C. W.; Hoss, J. A.; Grissino-Mayer, H. D. 2005. The contemporary fire regime of the central Appalachian Mountains and its relation to climate. Physical Geography. 26(2): 126-146.

Larson, D. L. 2003. Native weeds and exotic plants: relationships to disturbance in mixed-grass prairie. Plant Ecology. 169: 317-333.

Laughlin, D. C.; Bakker, J. D.; Stoddard, M. T.; [and others]. 2004. Toward reference conditions: wildfire effects on flora in an old-growth ponderosa pine forest. Forest Ecology and Management. 199: 137-152.

Mack, M. C.; D’Antonio, C. M. 1998. Impacts of biological invasions on disturbance regimes. TREE. 13(5): 195-198.

Marsh, M. A. 2005. Floristic dynamics of Appalachian pine-oak forests over a prescribed fire chronosequence. Morgantown, WV: West Virginia University. 275p. M.S. Thesis.

Maxwell, R. S. 2006. Establishing a historic benchmark for rimrock pine communities at New River Gorge National River, West Virginia. Morgantown, WV: West Virginia University. 97p. M.S. Thesis. 
McCarthy, B. C. 1997. Response of a forest understory community to experimental removal of an invasive nonindigenous plant (Alliaria petiolata, Brassicaceae). Pages 117-130 in: Luken, J. O.; Thieret, J. W., eds. Assessment and management of plant invasions. Springer, New York.

Mlot, C. 2003. Invasive Species West Virginia. Cambridge, MA: Union of Concerned Scientists.

Mooney, H. A.; Hobbs, R. J. 2000. Invasive Species in a Changing World. Washington, D.C.: Island Press.

Nuzzo, V. A. 1991. Experimental control of garlic mustard [Alliaria petiolata (Bieb.) Carva \& Grande] in northern Illinois using fire, herbicide, and cutting. Natural Areas Journal. 11: 158-167.

Nuzzo, V. A. 1992. Current and historic distribution of garlic mustard (Alliaria petiolata) in Illinois. Michigan Botanist. 32: 23-34.

Nuzzo, V. A. 1993. Distribution and spread of the invasive biennial garlic mustard (Alliaria petiolata) in North America. Pages 137-146 in: McKnight, B. N., ed. Biological pollution: the control and impact of invasive exotic species; proceedings of a symposium held at the Indiana University-Purdue University. October 25-26, 1991. Indiana Academy of Science. Indianapolis, IN. 261 p.

Nuzzo, V. 1999. Invasion pattern of the herb garlic mustard (Alliaria petiolata) in high quality forests. Biological Invasions. 1: 169-179.

Nuzzo, V. 2000. Element Stewardship Abstract for Alliaria petiolata. Arlington: The Nature Conservancy. $19 \mathrm{p}$.

Nuzzo, V. A; McClain, W.; Strole, T. 1996. Fire impact on groundlayer flora in a sand forest 1990-1994. American Midland Naturalist. 136(2): 207-221.

Oswalt, C. M.; Oswalt, S. M.; Clatterbuck, W. K. 2007. Effects of Microstegium vimineum (Trin.) A. Camus on native woody species density and diversity in a productive mixed-hardwood forest in Tennessee. Forest Ecology and Management. 242: 727-732.

Pimental, D.; Lach, L.; Zudiga, R. [and others]. 2000. Environmental and economic costs of nonindigenous species in the United States. BioSience. 50(1): 53-65.

Pyle, L. L. 1995. Effects of disturbance on herbaceous exotic plant species on the floodplain of the Potomac River. American Midland Naturalist. 134: 244-253.

Rentch, J. S.; Hicks, R. R, Jr. 2003. Canopy disturbance intervals, early growth rates, 
and canopy accession trends of oak-dominated old-growth forests. In: Van Sambeek, J. W.; Dawson, J. O.; Ponder, F, Jr.; [and others]., eds. Proceedings of the $13^{\text {th }}$ Central Hardwood Forest Conference. USDA Forest Service, Gen. Tech. Rep. NC-234.

Rice, P. M. 2005. Fire as a tool for controlling nonnative invasive plants. www.weedcenter.org/management/tools.htm\#burning. Bozeman, MT: Center for Invasive Plant Management.

Schuler, T. M.; McClain, W. R. 2003. Fire history of a Ridge and Valley oak forest. USDA Forest Service, Res. Pap. NE-724.

Shah, B. 1997. The checkered career of Ailanthus altissima. Arnoldia. 57(3): 20-27.

Shumway, D. L.; Abrams, M. D.; Ruffner, C. M. 2001. A 400-year history of fire and oak recruitment in an old-growth forest in western Maryland, U.S.A. Canadian Journal of Forest Research. 31: 1437-1443.

Smith, K. T.; Sutherland, E. K. 1999. Fire-scar formation and compartmentalization in oak. Canadian Journal of Forest Research. 29: 166-171.

Southern Appalachian Man and the Biosphere (SAMAB). 1996. The southern Appalachian assessment terrestrial technical report. USDA Forest Service, Rep. 5.

Stapanian, M. A.; Sundberg, S. D.; Baumgardner, G. A.; Liston, A. 1998. Alien plant species composition and associations with anthropogenic disturbance in North American forests. Plant Ecology. 139: 49-62.

Steavenson, H. A. 1946. Multiflora rose for farm hedges. Journal of Wildlife Management. 10(3): 227-234.

Steele, J.; Chandran, R. S.; Grafton, W. N.; [and others]. 2006. Awareness and management of invasive plants among West Virginia woodland owners. Journal of Forestry. 104(5): 248-253.

Stenkamp, H. E.; Chown, S. L. 1996. Influence of dense stands of an exotic tree, Prosopis glandulosa Benson, on a savanna dung beetle (Coleoptera: Scarabaeinae) assemblage in southern Africa. Biological Conservation. 78: 305311.

Stinson, K. A.; Campbell, S.A.; Powell, J. R.; [and others]. 2006. Invasive plant suppresses the growth of native tree seedlings by disrupting belowground mutualisms. PLoS Biology. 4(5): 727-731.

Sutherland, E. K.; Grissino-Mayer, H. D.; Woodhouse, C. A.; [and others]. 1995. Two 
centuries of fire in a southwestern Virginia Pinus pungens community. In Proceedings: IUFRO Conference on Inventory and Management in the Context of Catastrophic Events: Altered States of the Forest, University Park, PA. 21-24 June 1993. Pennsylvania State University, Center of Statistical Ecology and Environmental Statistics, University Park, PA.

Swearingen, J. 2008. WeedUS: Database of Plants Invading Natural Areas in the United States. 1p. http://www.nps.gov/plants/alien/list/WeedUS.xls. [Date Accessed: February 12, 2008].

Thomas-Van Gundy, M. T.; Nowacki, G. J.; Schuler, T. M. 2007. Rule-based mapping of fire adapted vegetation and fire regimes for the Monongahela National Forest. USDA Forest Service, Gen. Tech. Rep. NRS-12.

Tu, M. 2000. Element Stewardship Abstract for Microstegium vimineum. Arlington: The Nature Conservancy. $7 \mathrm{p}$.

USDA Forest Service, Eastern Region. 1998. Section 3B. Eastern region invasive plants, ranked by degree of invasiveness as based on information from states. $1 \mathrm{p}$. http://www.fs.fed.us/r9/wildlife/range/weed/Sec3B.htm. [Date Accessed: February 15, 2008].

Vitousek, P. M.; D’Antonio; C. M.; Loope, L. L.; Westbrooks, R. 1996. Biological invasions as global environmental change. American Scientist. 84: 468-478.

Vitousek, P. M.; Walker, L. R. 1989. Biological invasions by Myricacia faya in Hawaii: plant demography, nitrogen fixation, ecosystem effects. Ecological Monographs. 59: 247-265.

Waldrop, T. A.; Mohr, H. H.; Brose, P. H. 2006. Early dynamics of table mountain pine stands following stand-replacement prescribed fires of varying intensity. USDA Forest Service, Gen. Tech. Rep. SRS-92.

Wein, R. W.; Wein, G.; Bahret, S.; Cody, W. J. 1992. Northward invading non-native vascular plant species in and adjacent to Wood Buffalo National Park, Canada. Canadian Field-Naturalist. 106(2): 216-224.

Welch, N. T.; Waldrop, T. A.; Buckner, E. R. 2000. Response of southern Appalachian table mountain pine (Pinus pungens) and pitch pine (P. rigida) stands to prescribed burning. Forest Ecology and Management. 136: 185-197.

West Virginia Division of Natural Resources (WVDNR). 2003. Invasive plants in West Virginia. 1p. http://www.wvdnr.gov/Wildlife/InvasiveWV.shtm. [Date accessed: January 23, 2008].

Williams, C.E. 1998. History and status of table mountain pine-pitch pine forests of the 
southern Appalachian mountains (U.S.A.). Natural Areas Journal. 18: 81-90.

Williams, C. E.; Johnson, C. W. 1990. Age structure and the maintenance of Pinus pungens in pine-oak forests of southwestern Virginia. American Midland Naturalist. 124(1): 130-141.

Winter, K.; Schmitt, M. R.; Edwards, G. E. 1982. Microstegium vimineum, a shade adapted $\mathrm{C}_{4}$ grass. Plant Science Letters. 24: 311-318.

Wyman, D. 1949. Shrubs and Vines for American Gardens. New York, NY: Macmillan Company.

Yarnell, S. L. 1998. The southern Appalachians: a history of the landscape. USDA Forest Service, Gen. Tech. Rep. SRS-18. 


\section{CHAPTER 3}

Disturbance History and Ailanthus altissima (P. Mill.) Swingle Establishment in a Xeric Mixed-oak and Oak-pine Dominated Area in the Ridge and Valley of Eastern West Virginia 


\begin{abstract}
Descriptions of disturbance regimes allow for evaluations of recent theories about forest development and provide a better perception of forest community properties. This chapter focuses on characterizing the disturbance history of a 313.6 ha mountain composed of xeric mixed-oak and oak-pine forest communities. In addition to the general reconstructed disturbance history, the potential link between overstory tree-ofheaven (Ailanthus altissima (P. Mill.) Swingle) populations and prior forest management disturbances (i.e. harvesting) is investigated. The results indicated an age distribution and structure that is a result of multiple disturbances of varying intensities throughout the area. The majority $(81 \%)$ of the releases identified from percent growth change data were small and moderate, which were likely a result of death or removal of one or two trees that neighbored a sample tree. One study area-wide major disturbance event was identified around the turn of the $20^{\text {th }}$ century. For the most part, the only species to establish after the 1930s were chestnut oak (Quercus prinus L.), northern red oak (Quercus rubra L.), and Virginia pine (Pinus virginiana P. Mill.). Furthermore, most of the serotinous-coned yellow pines are not recruiting well in the understory. With respect to tree-of-heaven, most that had reached the main canopy were either in harvested areas, or along roads. All but one of the oldest tree-of-heaven post-dated the 1972 harvesting. Ground-layer vegetation around main tree-of-heaven stems is in danger of being severely impacted by vegetative reproduction (root suckers). Because the area is scheduled to burned, tree-of-heaven should be eradicated in these localized areas, prior to burning, to help protect future forest composition in the study area.
\end{abstract}




\section{Introduction}

The Ridge and Valley Physiographic Province of eastern West Virginia is characterized by its rugged and heterogeneous topography composed of dry slopes. Highly infertile sites that are inhospitable to mesophytic hardwood species are common throughout the area. The hot, dry hillsides in this area support xeric mixed-oak and oak-pine woodlands. The most common species found in these wooded communities include, chestnut oak (Quercus prinus L.), scarlet oak (Quercus coccinea Muenchh.), table mountain pine (Pinus pungens Lamb.), pitch pine (Pinus rigida P. Mill.), and Virginia pine (Pinus virginiana $\mathrm{P}$. Mill). These species possess certain silvical characteristics that allow for colonization and persistence on poor sites. All of the species, except chestnut oak, are classified as shade intolerant (Hicks 1998, Williams \& Johnson 1990). Chestnut oak is classified as intermediate in shade tolerance (Hicks 1998). All of the species have site adaptive root strategies as well (i.e. they tailor the physiologic processes in their roots to allow for the greatest survival and growth on a given site). For example, the pines possess the ability to root in underdeveloped soil and rock crevices (Williams \& Johnson 1990), while the oaks have superior root systems and a high root to shoot ratio. Other than scarlet oak, the species found in these forests are resistant to injuries from fire (Hicks 1998). Both the pines and the oaks have thick bark and the latter possesses a superb ability to compartmentalize injury (Smith and Sutherland 1999). Also, tablemountain pine and pitch pine possess serotinous cones (Williams \& Johnson 1990).

Historically, fire has played a key role in maintaining forest composition in pine-oak and mixed-oak forests in West Virginia and throughout the Appalachians (Abrams 1992, 
Brose and others 2001, Schuler and McClain 2003, Sutherland and others 1995). Before fire suppression became a policy in the eastern United States (US) between the late 1920s and 1950s, these forests were shaped by a combination of large scale disturbances (e.g. drought, stand-replacing wildfire, hurricane, and insect or disease outbreak) and lowintensity fires. Sutherland and others (1995) estimated that major fires occurred about every 10 to 15 years in table mountain pine stands in southwestern Virginia. Both Brose and Waldrop (2006b) and Yarnell (1998) estimated that prior to the fire suppression era, stand level disturbances in the southern Appalachians occurred once every 6 to 13 years. Rentch and Hicks (2003) found that large canopy disturbances involving multiple trees occurred every 17 years in oak dominated old-growth stands in the Central Hardwoods Region.

These types of disturbances formed stands of mixed-oak and pine, and the more frequent low-intensity fires maintained this composition (Abrams 1992, Brose and others 2001). Several studies have estimated low intensity fire return intervals in these forests. These return intervals are comparable to those of stand-level disturbances. Sutherland and others (1995) estimated that low intensity fires occurred every 9 to 11 years. Harmon (1982) found that periodic fires occurred, on average, about every 12 years in the Great Smoky Mountains. Shumway and others (2001) calculated fire-return intervals of 8 years in an oak forest in western Maryland. Schuler and McClain (2003) reported fire-return intervals of 7 to 15 years from 1895 to 2002 in an oak forest in the Ridge and Valley Physiographic Province of eastern West Virginia. Weibull median fire return intervals of 
4 to 8 years occurred in rimrock oak-pine communities at the New River Gorge National River in West Virginia (Maxwell 2006).

The diminution of fire as a disturbance agent, and the associated change in structure and species composition, has led to a decline of both oak and, especially, pine communities in some areas (Abrams 1992, Brose and Waldrop 2006a). Continued absence of fire in oakpine communities could soon lead to a decline in pine species, and eventual oak dominance (Abrams 1992, Sutherland and others 1995). Table mountain and pitch pine dominated communities, in particular, are recognized by the Southern Appalachian Man and the Biosphere (SAMAB), a program that encourages the utilization of ecosystem and adaptive management principles, as one of 31 rare communities (SAMAB 1996).

Researchers once thought that, without stand initiating fires, successful regeneration of table mountain and pitch pine communities could not occur (Sutherland and others 1995, Williams and Johnson 1990). Recent research, however, suggests that repeated low intensity fires can achieve successful table mountain pine regeneration (Waldrop and others 2006). Successful management of mixed-oak and oak-pine forests, without restoration of historical fire regimes, is difficult (Abrams 1992, Barden \& Woods 1976, Marsh 2005, Sutherland and others 1995, Welch and others 2000, Williams \& Johnson 1990).

In addition to the management challenges resulting from altered disturbance and fire regimes, the futures of these ecologically important forests are likely to be negatively affected by exotic invasive plants (Mlot 2003, Williams 1998). Highly invasive exotic 
plant species such as tree-of-heaven (Ailanthus altissima (P. Mill.) Swingle) are likely to drastically inhibit successful establishment and development of native plants and lead to a decrease in regional biodiversity (D'Antonio and Vitousek 1992) and altered ecosystem processes (Vitousek and Walker 1989). The highly invasive exotic tree-of-heaven is one of the most problematic exotic invasive species in the Appalachians and throughout the US.

Various types of evidence can be used for analyzing the timing, frequency, and magnitude of disturbances in forest communities, including: external physical evidence (fire scars, charcoal, uprooted trees), demographic evidence (age distribution), anatomical evidence (growth increment patterns), and structural evidence (canopy structure, diameter distribution) (Lorimer 1985). Furthermore, cohorts of similarly aged trees are one of the best indicators of past disturbance (Lorimer and Frelich 1989, Nowacki and Abrams 1992, Nowacki and Abrams 1997). Other than fire-scar analysis, disturbance (natural or anthropogenic) frequency and intensity in xeric mixed-oak and oak-pine forests of the Ridge and Valley has not been documented.

Since the mid- to late-1980s, the extent of prescribed fires has increased quite dramatically on federal lands in this area. In the decade of 1980, on average, 37.2 hectares/year were burned on the George Washington National Forest (GWNF), compared to 877.2 hectares/year in the 1990s and 2,097 hectares per year this decade. That equates to an astounding $2,240 \%$ increase from the 1980 s to the 1990 s, and a $140 \%$ increase from the 1990 s to the 2000 s, respectively. Concern for environmental quality is 
heightened when considering the increase in prescribed fire programs combined with observations that many exotic invasive species establish prolifically in freshly disturbed areas. As part of a study to assess the impact of prescribed fire on population dynamics of exotic invasive species, an investigation of the long-term, landscape-scale disturbance history was conducted on a 313.6 ha mountain composed of xeric mixed-oak and oakpine forest communities located on the GWNF in the Ridge and Valley Physiographic Province. The intent of this investigation was to explore evidence of forest canopy disturbances in the area in order to eliminate possible sources of variation in an associated study of the interaction between exotic invasives and prescribed fire.

This investigation had two primary objectives:

1. Identify forest canopy disturbances from the growth pattern of local trees using dendrochronology techniques.

2. Determine if a link exists between previous forest management disturbances (i.e. harvesting) and overstory tree-of-heaven populations.

A description of the disturbance regime will also allow for an evaluation of recent theories about forest development in these areas and provide a better perception of community properties. The information presented should help foresters and other land managers to better understand how disturbance frequency, intensity and severity might affect species composition and stand dynamics of this forest type. In addition to showing if harvesting played a role in tree-of-heaven establishment and distribution, the results of objective number two will provide GWNF managers with locations of localized tree-of- 
heaven infestation that may influence prescribed fire planning. For example prescribed fire managers may want to remove tree-of-heaven in these areas before burning. The study area is scheduled to be burned again in the spring of 2008 (S. Croy, EcologistGWNF, personal communication).

\section{Methods}

\section{Study Site}

The study site, a mountain known as Dunkle Knob, encompasses 313.6 ha and is composed of xeric mixed-oak and oak-pine forest communities. Based on a 2007 inventory, the most abundant overstory species (trees $\geq 12.7 \mathrm{~cm}$ diameter at breast height (DBH)) species include chestnut oak, Virginia pine, and table mountain pine (Table 3.1). The understory mixture (trees $\leq 1 \mathrm{~m}$ in height) is well represented by red maple (Acer rubrum L.), striped maple (Acer pensylvanicum L.), and pignut hickory (Carya glabra (P. Mill.) Sweet) (Table 3.2).

The study site is located on the North River Ranger District (formerly the Dry River Ranger District) of the GWNF, Pendleton County, West Virginia ( $38^{\circ} 37^{\prime} \mathrm{N}, 79^{\circ} 14^{\prime} \mathrm{W}$ ). The area is within the Ridge and Valley Physiographic Province and is in the rain shadow of the Allegheny Mountains, which causes a climate that is much drier than the rest of the state (Core 1966). The area is characterized by an average annual precipitation of $82 \mathrm{~cm}$, an average annual temperature of $10.9^{\circ} \mathrm{C}$, and a growing season of approximately 144 days (Estepp 1992). Forests of the region can be characterized as being part of the former oak-chestnut cover type (Braun 1950). 
Table 3.1. Mean overstory composition values (IV $=0.5 *($ relative density + relative basal area $)$ ).

\begin{tabular}{|c|c|c|c|}
\hline Species & Basal Area (m²/ha) & Density (trees/ha) & Importance Value (IV) \\
\hline Acer pensylvanicum & 0.08 & 5.56 & 0.77 \\
\hline Acer rubrum & 0.41 & 18.89 & 2.90 \\
\hline Acer saccharum & 0.06 & 1.11 & 0.26 \\
\hline Ailanthus altissima & 0.03 & 0.56 & 0.12 \\
\hline Amelanchier arborea & 0.02 & 1.11 & 0.17 \\
\hline Betula lenta & 0.08 & 1.11 & 0.29 \\
\hline Carya glabra & 1.30 & 46.11 & 7.71 \\
\hline Carya ovata & 0.01 & 0.56 & 0.08 \\
\hline Carya tomentosa & 0.09 & 3.89 & 0.62 \\
\hline Nyssa sylvatica & 0.08 & 3.89 & 0.58 \\
\hline Ostrya virginiana & 0.05 & 3.33 & 0.47 \\
\hline Pinus pungens & 2.19 & 51.67 & 10.25 \\
\hline Pinus rigida & 1.19 & 26.11 & 5.36 \\
\hline Pinus strobus & 0.89 & 22.22 & 4.30 \\
\hline Pinus virginiana & 2.14 & 65.00 & 11.55 \\
\hline Prunus serotina & 0.03 & 1.11 & 0.18 \\
\hline Quercus alba & 0.13 & 3.89 & 0.69 \\
\hline Quercus coccinea & 0.32 & 8.33 & 1.57 \\
\hline Quercus prinus & 10.94 & 127.78 & 37.37 \\
\hline Quercus rubra & 1.27 & 34.44 & 6.42 \\
\hline Quercus velutina & 0.86 & 13.89 & 3.33 \\
\hline Robinia pseudoacacia & 0.41 & 15.56 & 2.54 \\
\hline Sassafras albidum & 0.22 & 10.56 & 1.59 \\
\hline Tsuga canadensis & 0.19 & 4.44 & 0.88 \\
\hline Total & 22.98 & 471.11 & 100.00 \\
\hline
\end{tabular}

The topography is highly dissected with slopes ranging from 6 to $70 \%$. Elevation ranges from 573 to $848 \mathrm{~m}$. The predominant soil type is of the Berks-Weikert association. They are loamy-skeletal, mixed, Dystrochrepts formed from acidic shale, siltstone, or sandstone bedrock. The soils are droughty, infertile, and often contain numerous rock outcroppings (Estepp 1992). 
Table 3.2. Mean understory composition values (IV $=0.5 *$ (relative density + relative percent cover)).

\begin{tabular}{lccc}
\hline Species & Cover (\%) & Density (trees/ha) & Importance Value (IV) \\
\hline Acer pensylvanicum & 6.88 & 7361.11 & 11.63 \\
Acer rubrum & 17.71 & 12986.11 & 22.60 \\
Ailanthus altissima & 0.07 & 69.44 & 0.11 \\
Amelanchier arborea & 8.19 & 2083.33 & 5.63 \\
Carya glabra & 22.29 & 2222.22 & 11.06 \\
Fraxinus americana & 0.28 & 69.44 & 0.19 \\
Nyssa sylvatica & 9.44 & 1736.11 & 5.67 \\
Ostrya virginiana & 5.56 & 2569.44 & 5.24 \\
Pinus rigida & 0.28 & 69.44 & 0.19 \\
Pinus strobus & 0.56 & 416.67 & 0.72 \\
Pinus virginiana & 5.56 & 3402.78 & 6.26 \\
Prunus serotina & 0.69 & 138.89 & 0.43 \\
Quercus prinus & 18.96 & 2847.22 & 10.59 \\
Quercus rubra & 6.39 & 1250.00 & 3.93 \\
Quercus velutina & 21.25 & 1458.33 & 9.73 \\
Robinia pseudoacacia & 2.71 & 347.22 & 1.44 \\
Sassafras albidum & 7.01 & 1597.22 & 4.59 \\
Total & 133.82 & 40625.00 & 100.00 \\
\hline
\end{tabular}

The site was purchased by the United States Department of Agriculture (USDA) Forest Service in 1923. After its purchase, no fires were documented in the Dunkle Knob area until a prescribed fire was ignited by GWNF personnel in March of 2004 (Marsh 2005). Five timber sales were documented in the study area after 1923. This harvesting occurred on and around the base of the mountain in the 1950s and 1960s, as well as in the early 1970s and 1980s (Figure 3.1) ${ }^{1}$.

${ }^{1}$ Data on file with the USDA Forest Service, GWNF, North River Ranger District, Harrisonburg, VA. 


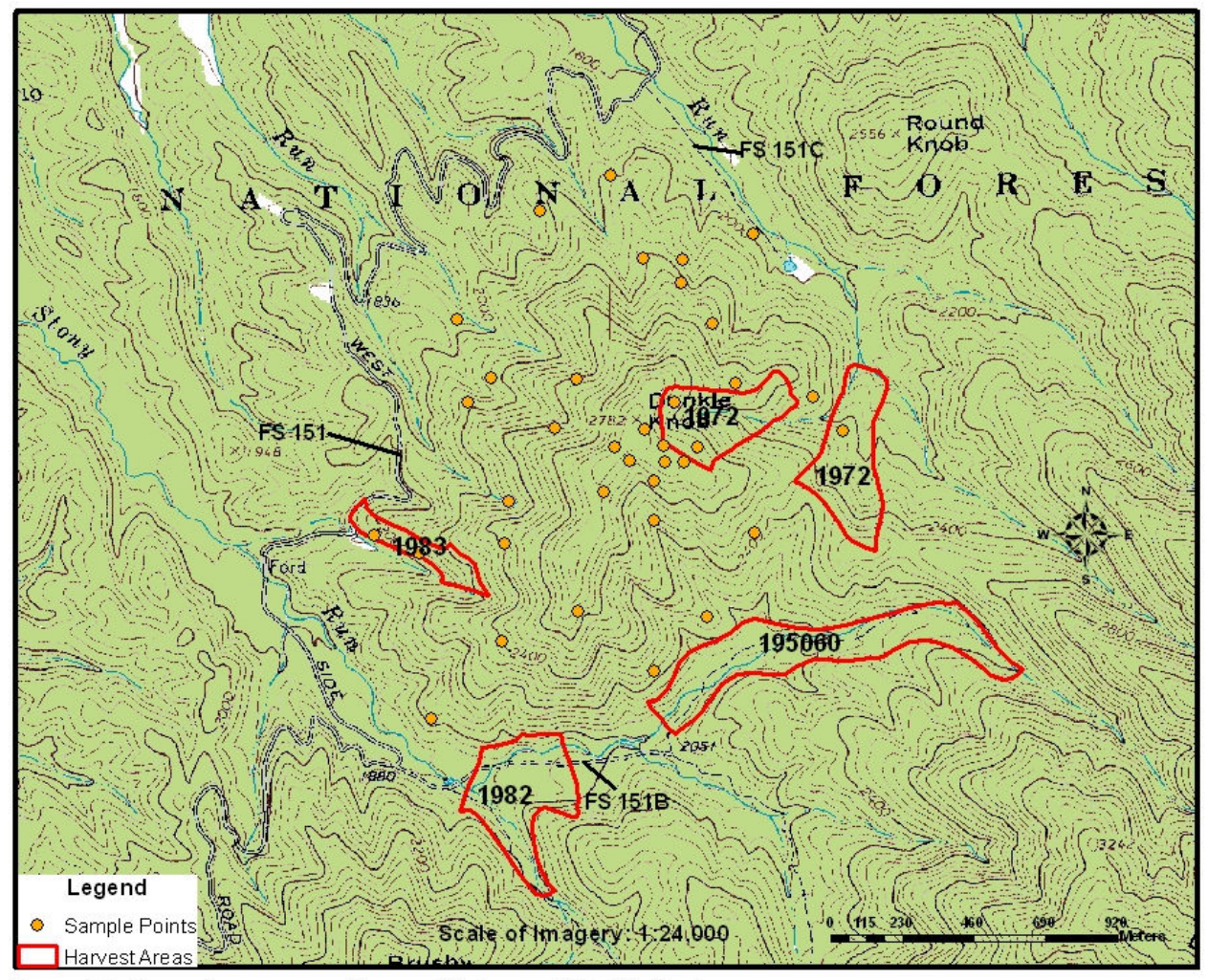

Figure 3.1. Harvest areas on, and around the base of, Dunkle Knob.

Harvesting on the mountain was restricted to lower, easily accessible, slopes and in a cove area where higher value timber would have resided (Figure 3.1). The area was first entered to extract timber in the 1950s via Forest Service Road 151B. A 14.6 ha area at the southeastern base was the target. During both the 1950s and 60s this area was selectively cut leaving a "sparse overstory of poorer material." Timber Stand Improvement (TSI) was applied in 1978 with USFS personnel injecting undesirable trees with 2,4-D. The Dunkle Knob area was harvested again in 1972. This time, two areas, one in a cove ( $8.0 \mathrm{ha})$ and one on a lower slope ( $8.8 \mathrm{ha})$, on the northeastern side of the mountain were clearcut. These areas were accessed via extensions off of Forest Service Road 151C (Figure 3.1). Following timber removal, site preparation for natural 
regeneration of hardwoods on these areas was carried out by injecting 2,4-D into all stems greater than $5.1 \mathrm{~cm} \mathrm{DBH}$ or greater than $4.6 \mathrm{~m}$ tall. Three of the current study sample points fell into these areas that were cut in 1972 (Figure 3.1). Ten years later an 8.4 ha area was harvested at the southerly base of the mountain. The harvest type in this area was a clearcut with ten total reserve trees. The following year (1983) a similar cut (clearcut with four total reserve trees) was applied to a 4.0 ha lower slope area on the southwestern side of the mountain. Chainsaw site preparation for natural regeneration was used following the two most recent harvests. Eastern white pine (Pinus strobus L.) was planted in some cases after harvesting.

\section{Field Methods}

Eighteen circular 0.05 ha plots were randomly established on northeast- $\left(315-235^{\circ}\right)$ and southwest- $\left(236-314^{\circ}\right)$ facing slopes (36 total). Nine plots each were established above and below $748 \mathrm{~m}$ elevation, stratifying the mountain into four sampling areas: northeast aspect/upper slope (NEU), northeast aspect/lower slope (NEL), southwest aspect/upper slope (SWU), and southwest aspect/lower slope (SWL) (see Marsh (2005) for complete sampling experimental design). To aid in future relocation, sample points were marked with a Global Positioning System (GPS) and a piece of steel rebar was driven into the ground and marked with flagging at each plot center.

Each plot was inventoried in the summer of 2007 to assess stand composition. All trees having a DBH greater than $12.7 \mathrm{~cm}$ were sampled and identified to species. DBH was measured to the nearest $0.1 \mathrm{~cm}$ using a diameter tape. 
A total of 165 cores were used in the disturbance reconstruction analysis (Table 3.3). At least one increment core was extracted at each plot in the summer of 2004 using an increment borer. Cores were extracted at breast height ( $1.3 \mathrm{~m}$ above the ground) and parallel to topography to avoid tension or compression wood. Larger, and presumably older, trees were preferentially selected in hopes of obtaining the longest chronological records available. No trees having a $\mathrm{DBH}<3.5 \mathrm{~cm}$ were sampled.

Table 3.3. Number of cores by species.

\begin{tabular}{lc}
\hline Species & \# Cores \\
\hline Pinus pungens & 25 \\
Pinus rigida & 14 \\
Pinus strobus & 14 \\
Pinus virginiana & 26 \\
Quercus prinus & 59 \\
Quercus rubra & 27 \\
Total & 165 \\
\hline
\end{tabular}

To assess how harvesting related to the establishment of the exotic invasive tree-ofheaven, a GPS was used in the summer of 2007 to mark waypoints of areas where treeof-heaven had ascended into the main canopy. The sampling method can be described as a landscape-level timed meander. Areas with single or multiple tree-of-heaven stems were identified while traversing the mountain between June 2007 and August 2007. Although it is difficult to say how close the sample came to enumerating all of the pockets of tree-of-heaven across the mountain, they were easy to spot because an abundance of 0.5 to $3.5 \mathrm{~m}$ tall tree-of-heaven regeneration (likely adventitious shoots, or suckers, arising from parent tree roots) was always surrounding main canopy level stems (J. Pomp, personal observation; Figure 3.2). Increment cores $(n=37)$ were extracted 
from both large and small tree-of-heaven in these areas. The largest tree-of-heaven was always cored and no stems having a $\mathrm{DBH}<8.0 \mathrm{~cm}$ were sampled.

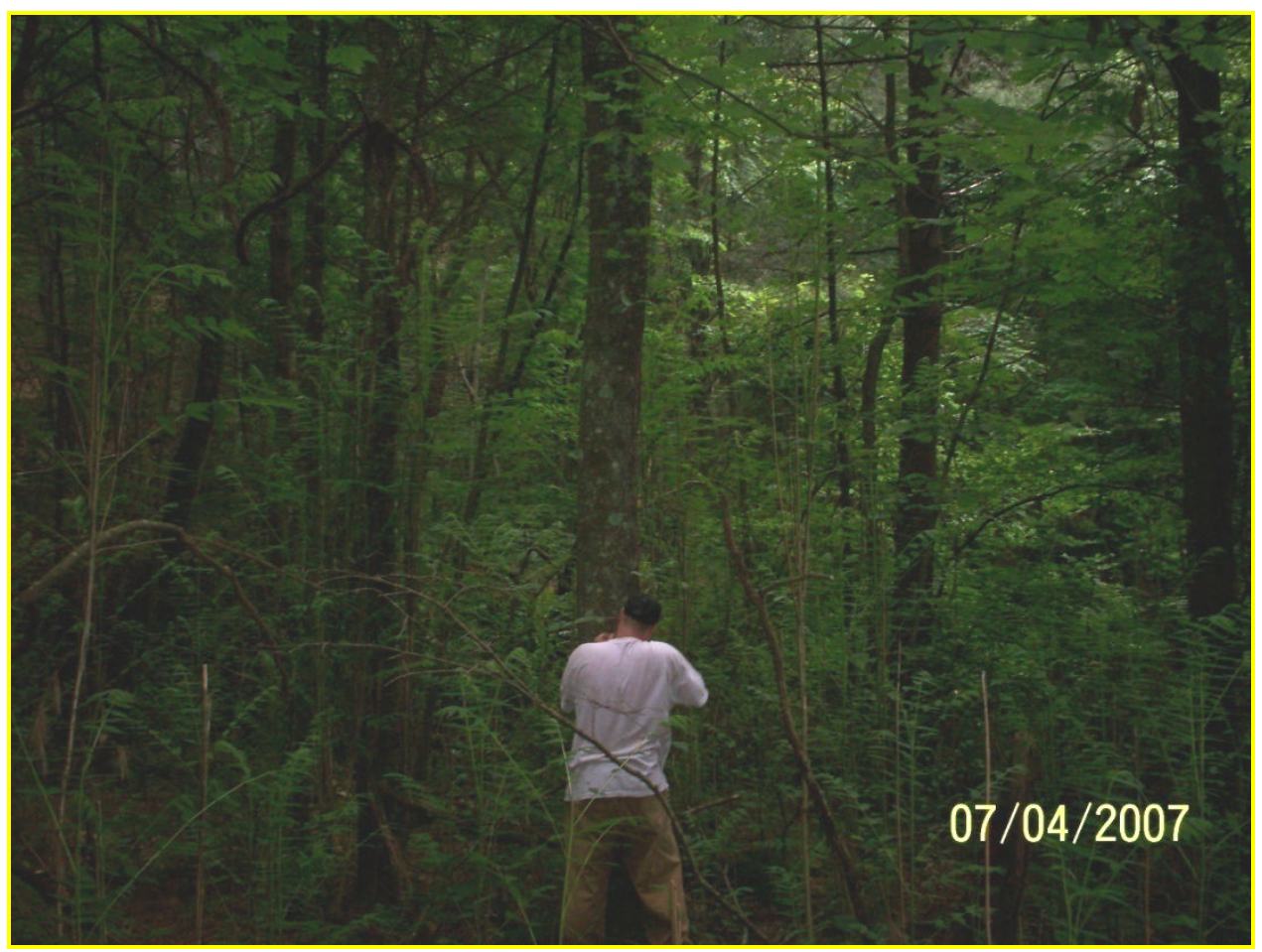

Figure 3.2. Abundant regeneration surrounding a co-dominant tree-ofheaven on Dunkle Knob. The man in the picture is just less than two meters tall.

\section{Laboratory Techniques}

All cores were dried, mounted, and then sanded with progressively finer grit sandpaper to expose the annual rings (Stokes \& Smiley 1968). Growth rings were dated for all species. Ring widths were measured for chestnut oak and all of the sampled pine species. Unfortunately, due to time constraints, the ring widths of northern red oak (Quercus rubra L.) and tree-of-heaven samples were not measured. Widths were measured to the nearest $0.001 \mathrm{~mm}$ using a Leica Stereo Zoom-5 binocular microscope, an Acu-rite measuring stage and a Quick-Check 1000 digital readout, in conjunction with Measure 
$\mathrm{J} 2 \mathrm{X}^{\circledR}$ software. Dating and measurements were validated using the program COFECHA (Grissino-Mayer and others 1997).

\section{Data Analysis}

Diameter distribution

The 2007 inventory data was summarized into four centimeter diameter classes to create a stand table (Trees per Hectare (TPH) by diameter class and species) of the three most abundant (based on relative basal area) overstory species in each sampling area. These tables were converted into a histogram for visual analysis.

$\underline{\text { Age distribution }}$

For graphical comparison, DBH was plotted over establishment date for each sample tree by sampling area.

\section{Growth Increment Patterns}

Growth releases were identified from tree ring widths using the radial growth averaging technique proposed by Nowacki and Abrams (1997). Percent growth change (\% GC) was calculated using the equation:

$$
\% G C=\left[\left(M_{2}-M_{1}\right) / M_{1}\right] \times 100,
$$

where $\mathrm{M}_{1}=$ preceding 10-year mean radial growth (inclusive of the disturbance year), and $\mathrm{M}_{2}=$ subsequent 10-year mean (exclusive of the disturbance year) (Nowacki and 
Abrams 1997). Percent GC was calculated for each sample tree $(n=165)$ and averaged for each species, except northern red oak and tree-of-heaven, in each sampling area to produce master chronologies. Because of the low number of samples, pitch pine and table mountain pine data were combined for the master chronology calculation, with the exception of cores taken from the SWL sampling area. In addition, residuals from plots that fell in the harvested areas were analyzed separately. Two chestnut oak residuals were sampled in 1972 harvest area, while three residuals (two eastern white pines and one pitch pine) were sampled in the 1983 harvest area.

To assess how climatic trends affected radial growth responses, yearly reconstructed Palmer Drought Severity Index (PDSI) data were collected for the region (National Climactic Data Center 2006). The yearly PDSI data were converted to PDSI differences (PDSI $\left.\mathrm{Piff}_{\text {f }}\right)$ using the formula:

$$
P D S I_{\text {diff }}=P_{2}-P_{1}
$$

where $\mathrm{P}_{1}=$ preceding 10 -year PDSI mean, and $\mathrm{P}_{2}=$ subsequent 10 -year PDSI mean (Nowacki and Abrams 1997). Simple linear regression analyses were performed examine

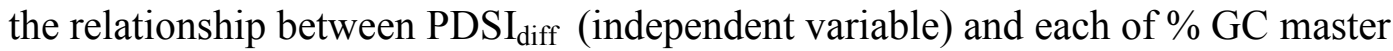
chronologies. The highest recorded PDSI $_{\text {diff }}$ for each species/study area combination was then inserted into the resulting regression equations to roughly estimate the upper limits of influence on \% GC master chronologies (Nowacki and Abrams 1997). If the resulting values were higher than $25 \%$, the release detection thresholds were adjusted upward 
accordingly. Based on thinning data and polynomial regression equations relating $\% \mathrm{GC}$ to basal area reductions, the $25 \%$ minimum release detection threshold can be considered conservative, and is an appropriate threshold for documenting canopy disturbances in oak forests (Nowacki and Abrams 1997).

For each sample tree, releases were identified as abrupt and sustained periods of $\% \mathrm{GC}$ that were above the $25 \%$, or the regression equation determined, threshold. Major releases were identified as events where $\% \mathrm{GC} \geq 100 \%$, while moderate releases were identified by \% GC values between 50 and $99 \%$ (Lorimer and Frelich 1989). Small releases were identified as events where \% GC values ranged from 25 to $49 \%$ (Schuler and Fajvan 1999, Rentch and Hicks 2003).

The numbers of releases were tabulated by decade for each of the four sampling areas. Using this data, major disturbance decades were denoted as peaks comprised of $>25 \%$ of the sample trees (Nowacki and Abrams 1997). Major disturbance events were not assigned unless at least two trees exhibited a release (Nowacki and Abrams 1997). Furthermore, because of the drier nature of the study site, major disturbances that occurred during positive peaks of PDSI diff $_{\text {(decades of } 1810,1820,1960 \text {, and 1970) }}$ (Figure 3.3) were simply considered increases in tree growth due to favorable climate shifts. 


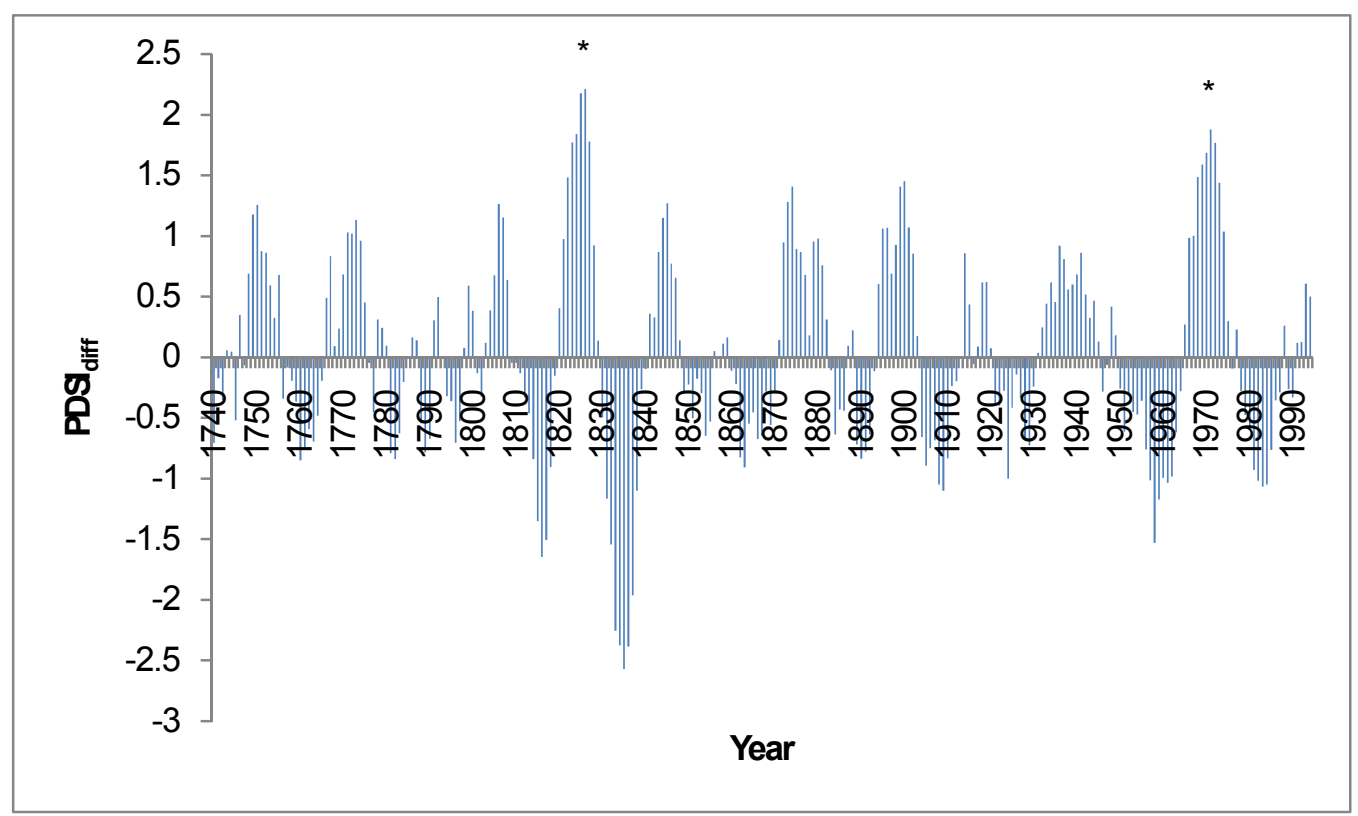

Figure 3.3. PDSI $_{\text {diff }}$ chronology for the Dunkle Knob area. * indicates period when favorable climate would have positively affected tree growth.

Frequencies, or return intervals, of major disturbances were determined in each sampling area for both the exploitation era (prior to 1900) and the modern era (after 1900). Exploitation era frequencies were calculated using the equation:

$$
\text { Disturbance Frequency } \text { exploitation }=\frac{1900-\text { old }_{s}}{d_{s}},
$$

where old $=$ date of the first year $\%$ GC could be calculated in the sampling area s, and $\mathrm{d}$ $=$ number of major disturbances. Modern era frequencies were calculated by dividing 94 (length of $\% \mathrm{GC}$ chronologies in modern era) by the number of major disturbances. In both cases, evident age cohorting was also counted as a major disturbance. 
In addition, average early growth rates and overall average growth patterns were analyzed to determine the canopy accession trends for each species in each sampling area. Species were considered gap origin if their growth rate during the first twenty-five years was high, and if the overall growth pattern was flat or slightly decreasing (Lorimer, 1985, Lorimer and Frelich 1989, Nowacki and Abrams 1997, Rentch and Hicks 2003). Species were considered gap origin - gap release if they displayed a high early growth rate and a growth pattern that exhibited subsequent reduced growth, followed by a major release (Rentch and Hicks 2003). Species were considered understory origin - gap release if their growth rate was low during the first twenty-five years and exhibited one or more major releases (Lorimer and Frelich 1989, Nowacki and Abrams 1997, Rentch and Hicks 2003).

\section{$\underline{\text { Tree-of-heaven Age and Distribution }}$}

Waypoints of areas where tree-of-heaven had ascended into the main canopy were overlaid on the harvested areas shapefile using ArcMap 9.1 software (C) Environmental Systems Research Institute (ESRI), Redlands, USA 2005). Establishment date was added to the attribute table of the waypoint shapefile. Maps were produced for visual examination and interpretation.

\section{Results}

\section{Diameter Distribution}

Diameter distributions were quite similar for all four sampling areas of the study site. These exhibited the classic "reverse-J" distribution shape, characteristic of an uneven- 
aged structure (Figures 3.4 - 3.7). Forests with this structure are composed essentially of even-aged stands or groups of different ages (Smith 1997). For the most part, chestnut oak dominated the larger size classes in all four sampling areas. Virginia pine was one of the three most abundant species in the southwestern areas, while pignut hickory expressed high abundance on the upper slopes and table mountain pine on lower slopes. Pitch pine was present as one of the three most abundant species only in the NEL sampling area.

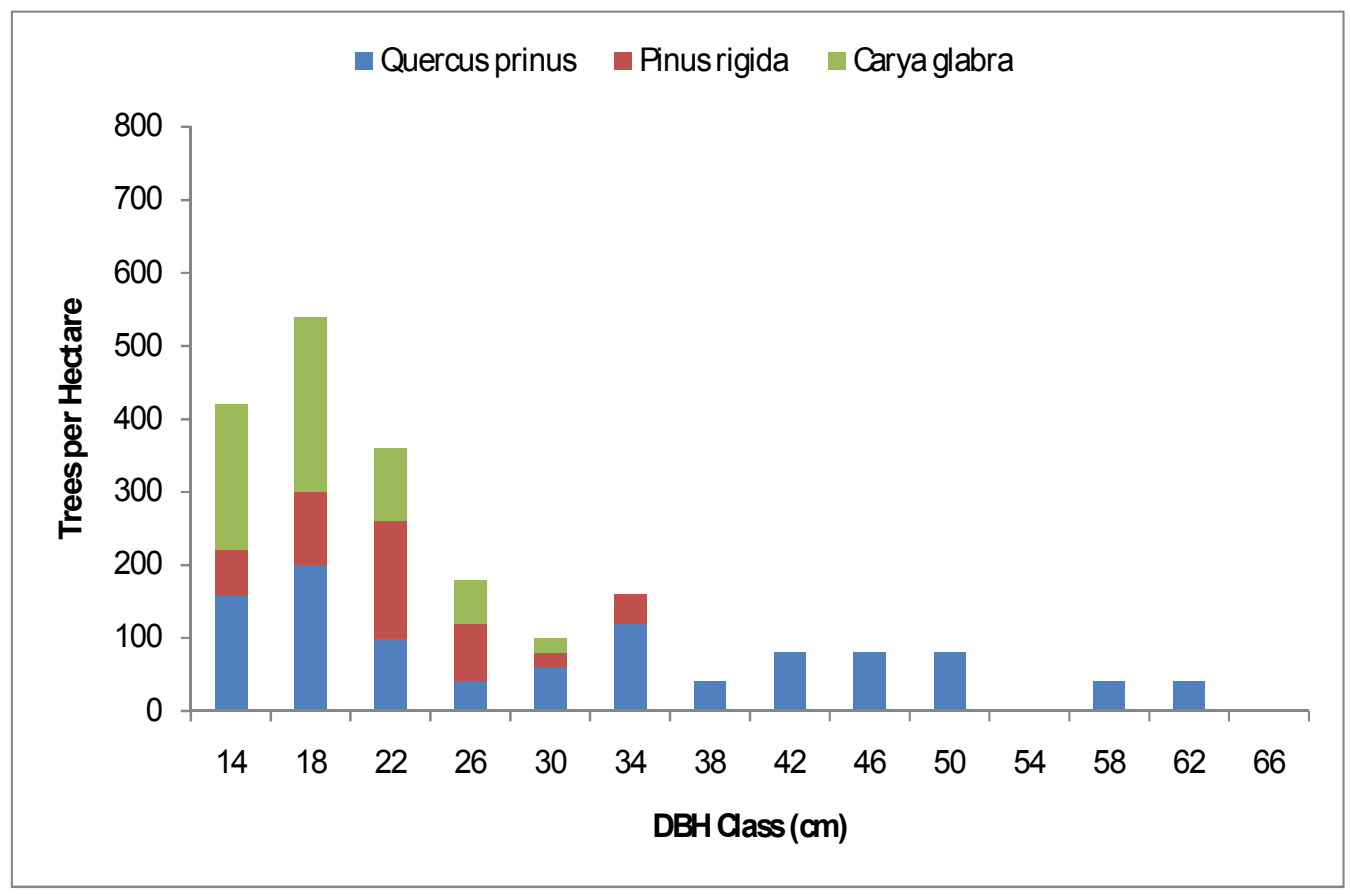

Figure 3.4. Diameter distributions for the three most abundant species: NEU. 


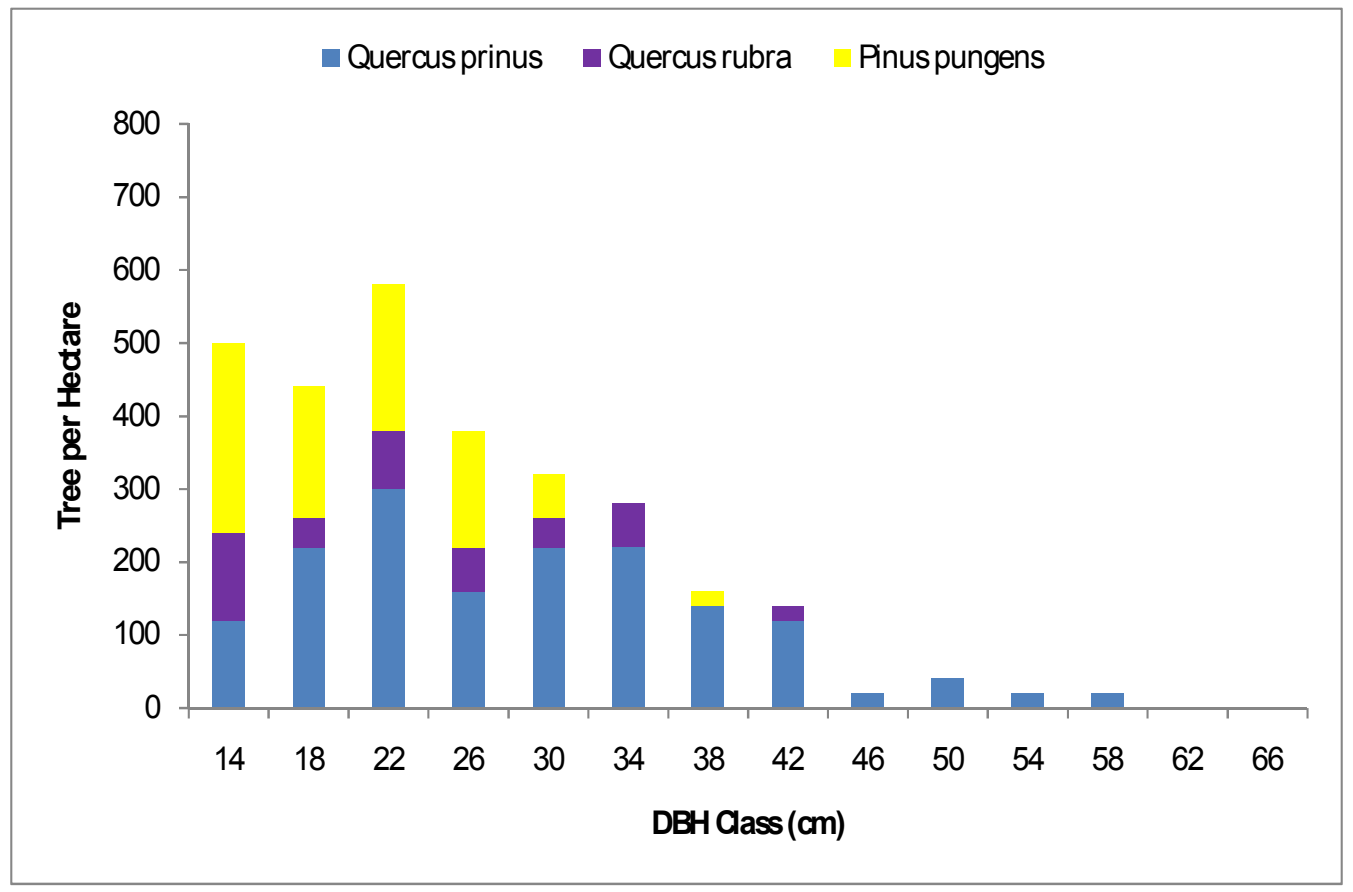

Figure 3.5. Diameter distributions for the three most abundant species: NEL

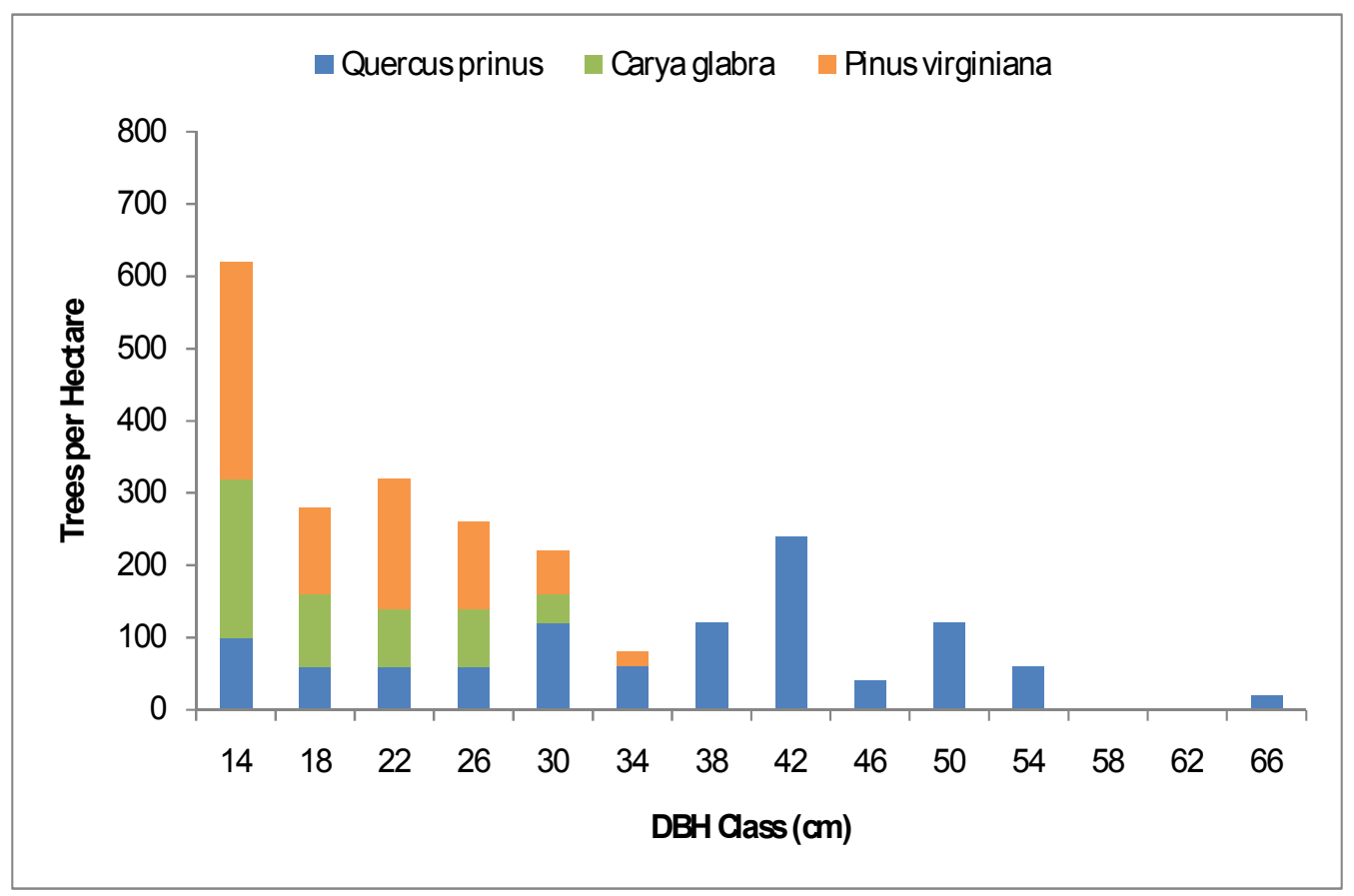

Figure 3.6. Diameter distributions for the three most abundant species: SWU 


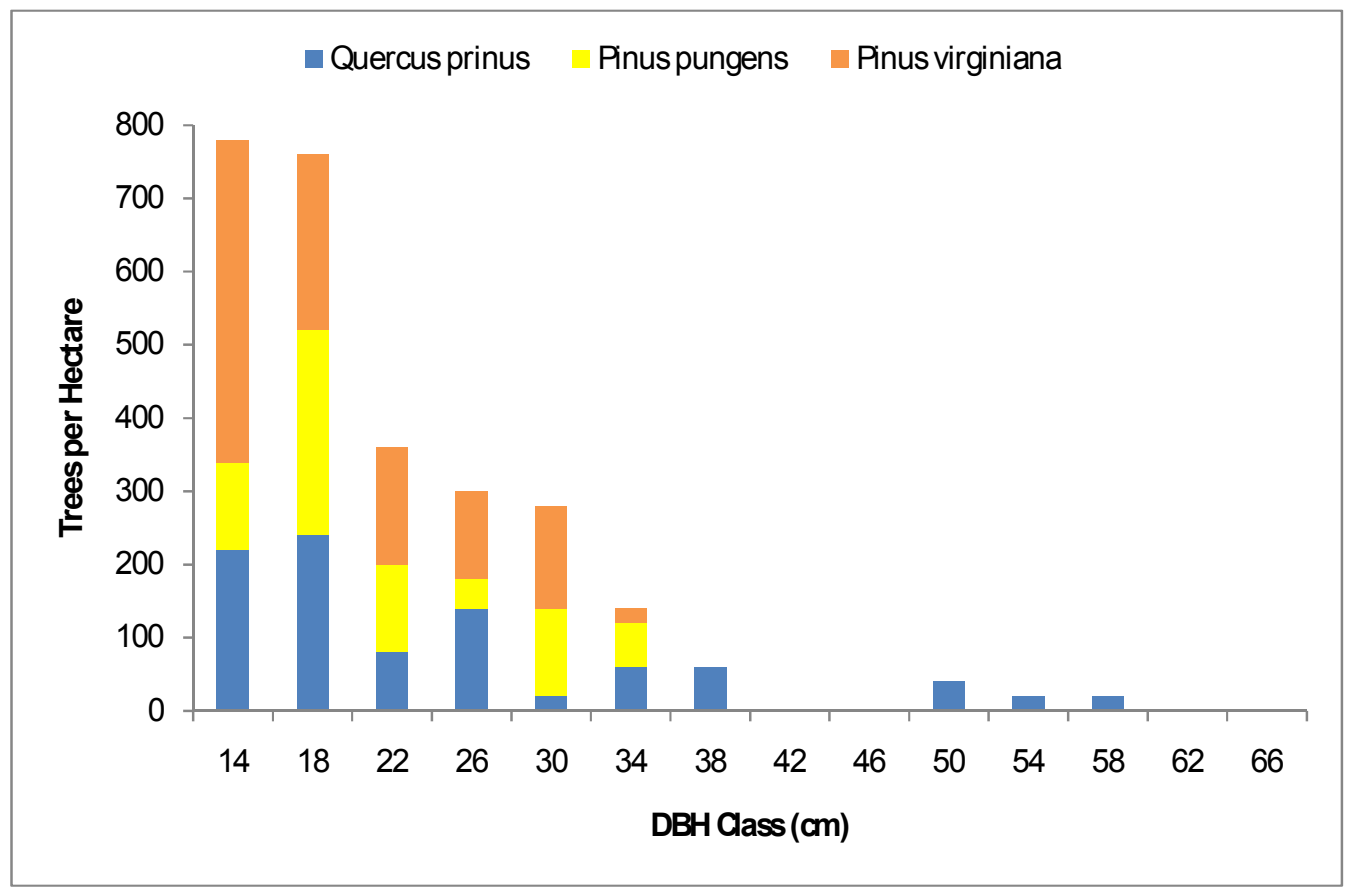

Figure 3.7. Diameter distributions for the three most abundant species: SWL

\section{Age Distribution}

Age distributions were also quite similar for all four sampling areas. They provided further evidence of uneven-aged structure, containing at least two to four recognizable cohorts (Figures 3.8 - 3.11, top). In all areas, the youngest of these cohorts arose around the turn of the twentieth century (1890 to 1910). More trees established in the decade of 1910 than any other decade examined. There has been more or less continuous establishment ever since. The oldest of the sample trees, a chestnut oak, originated in 1741 the NEL sampling area (Figure 3.9, top). All sampling areas contain at least one cohort that developed prior to 1850 . These old cohorts are composed of only chestnut oak. 


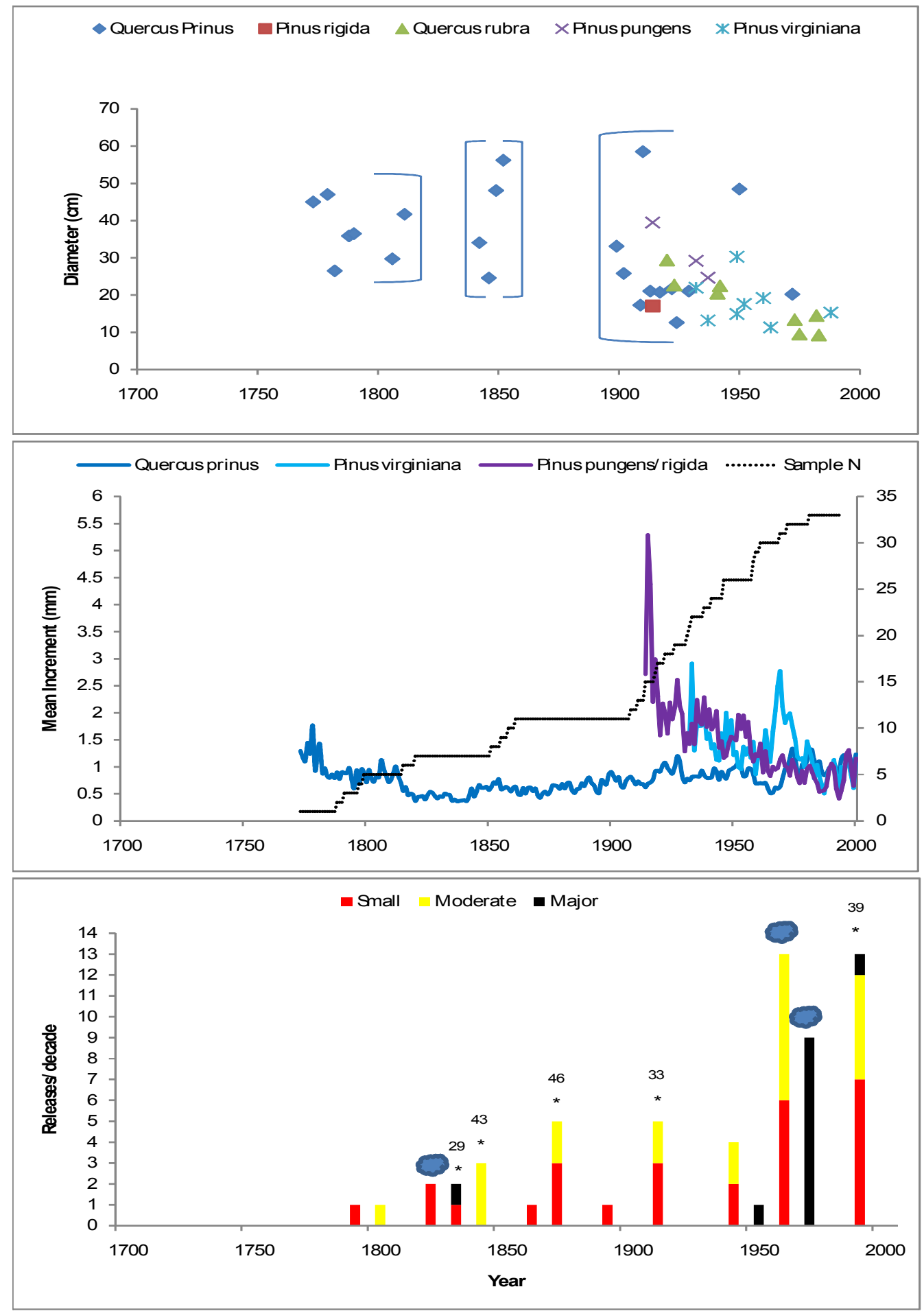

Figure 3.8. A comparative compilation of age-diameter relations (top), average growth patterns (middle), and number of releases (bottom) in the NEU sampling area. Brackets denote cohorts (top). Asterisks indicate decades in which a major disturbance occurred and clouds indicate decades when favorable climate would have positively affected tree growth (bottom). The percentage of sample trees showing releases during major disturbances are listed above the asterisks. 


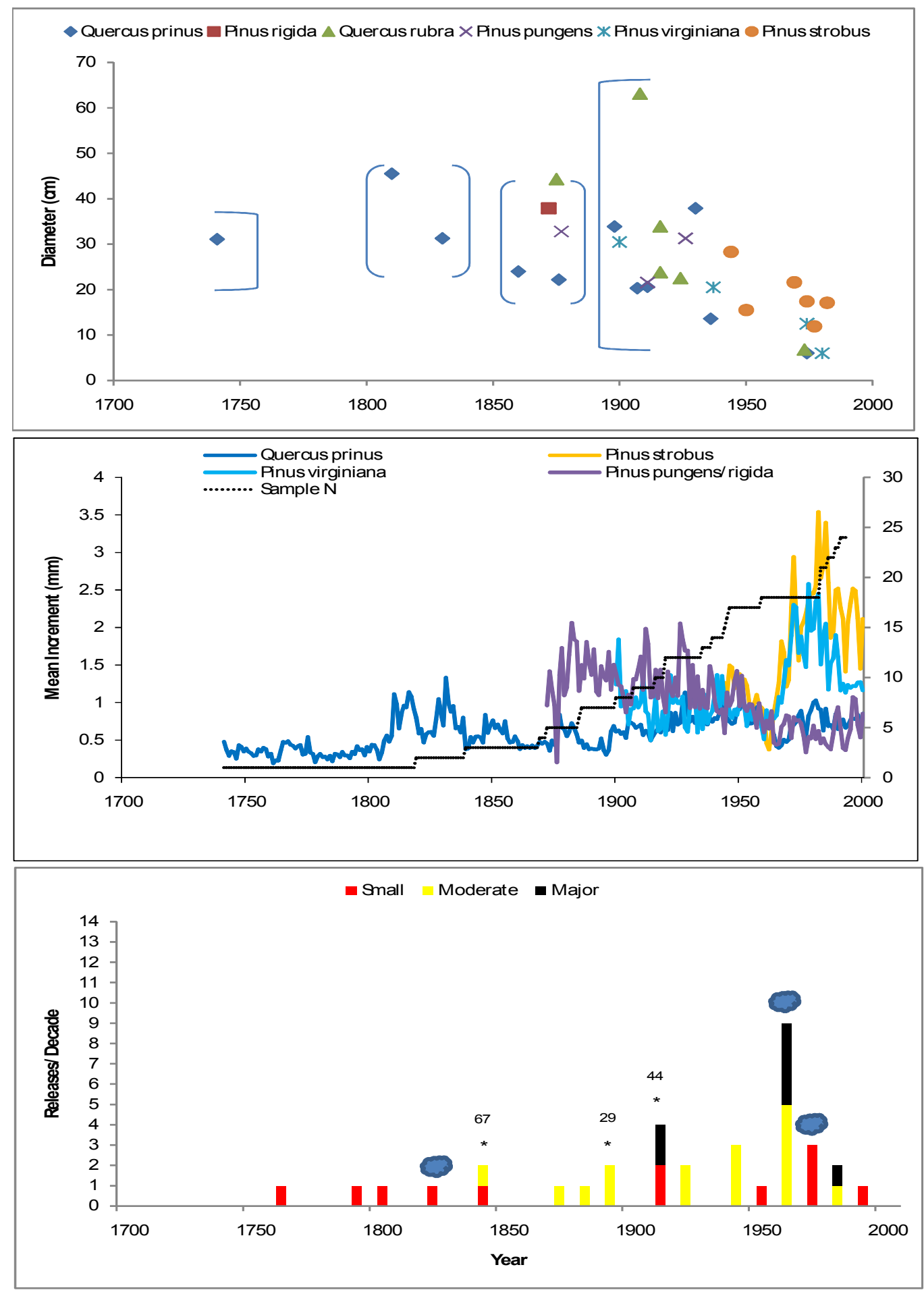

Figure 3.9. A comparative compilation of age-diameter relations (top), average growth patterns (middle), and number of releases (bottom) in the NEL sampling area. Brackets denote cohorts (top). Asterisks indicate decades in which a major disturbance occurred and clouds indicate decades when favorable climate would have positively affected tree growth (bottom). The percentage of sample trees showing releases during major disturbances are listed above the asterisks. 

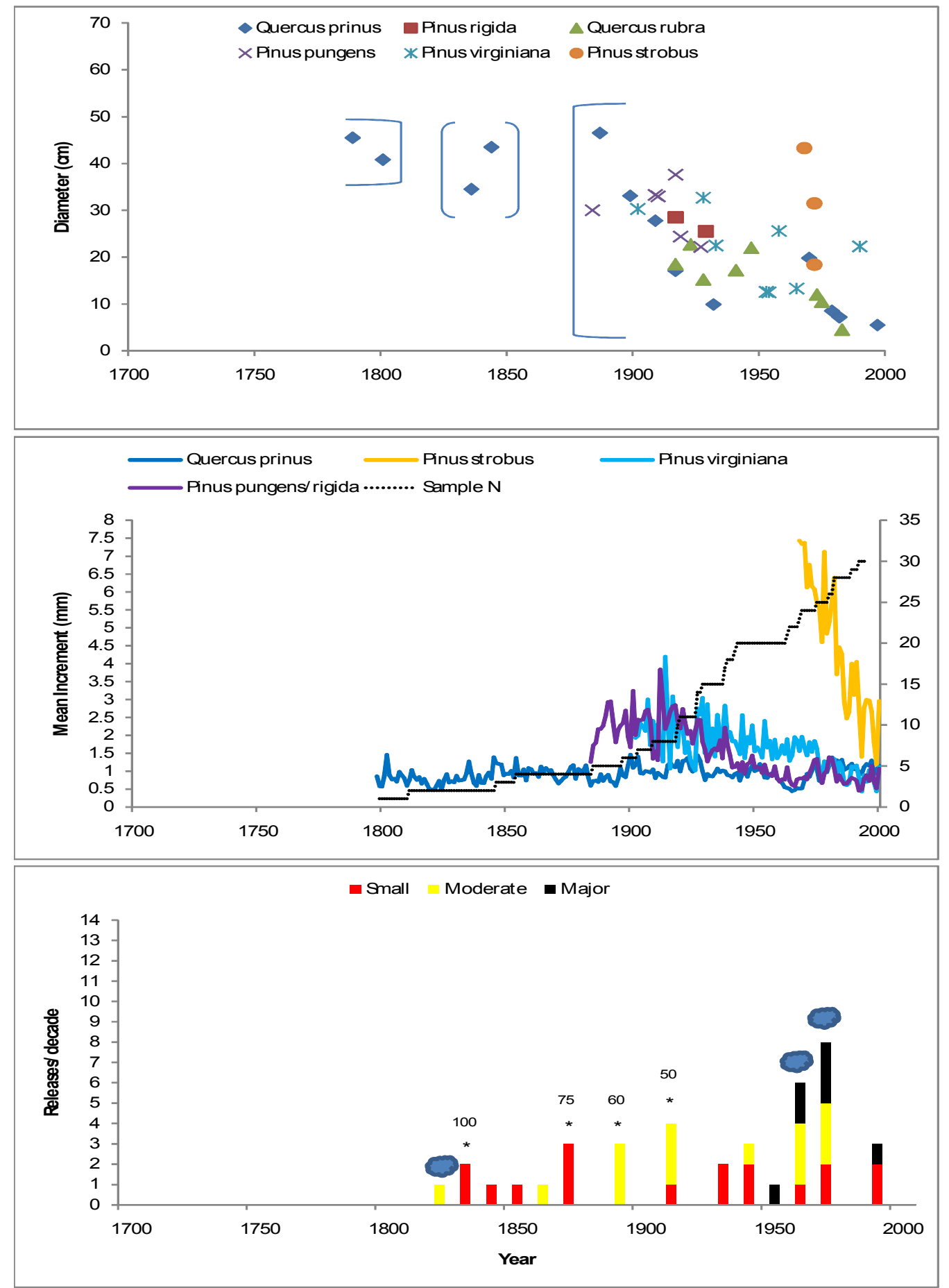

Figure 3.10. A comparative compilation of age-diameter relations (top), average growth patterns (middle), and number of releases (bottom) in the SWU sampling area. Brackets denote cohorts (top). Asterisks indicate decades in which a major disturbance occurred and clouds indicate decades when favorable climate would have positively affected tree growth (bottom). The percentage of sample trees showing releases during major disturbances are listed above the asterisks. 

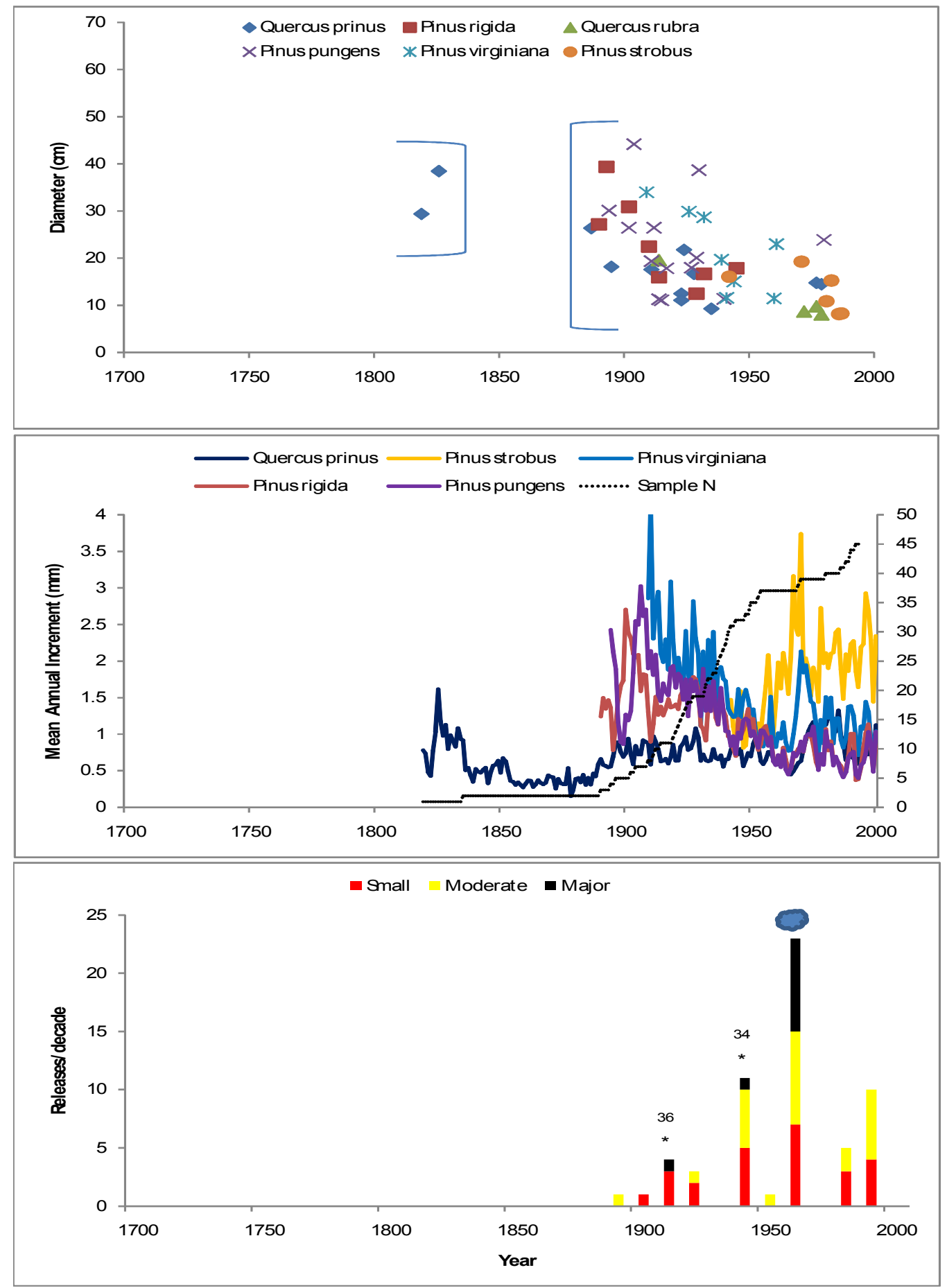

Figure 3.11. A comparative compilation of age-diameter relations (top), average growth patterns (middle), and number of releases (bottom) in the SWL sampling area. Brackets denote cohorts (top). Asterisks indicate decades in which a major disturbance occurred and clouds indicate decades when favorable climate would have positively affected tree growth (bottom). The percentage of sample trees showing releases during major disturbances are listed above the asterisks. 


\section{Growth Increment Patterns}

Fifteen of the $19(\approx 79 \%) \%$ GC master chronologies showed significant positive linear relationships with PDSI $I_{\text {diff }}$ (Table 3.4). For these chronologies, the upper \% GC responses due to climate ranged from 1.36 to $67.79 \%$. Eight of these values exceeded the Nowacki and Abrams (1997) $25 \%$ release detection threshold (Table 3.4).

Table 3.4. Regression analyses relating \%GC master chronologies to PDSI $_{\text {diff. }}$

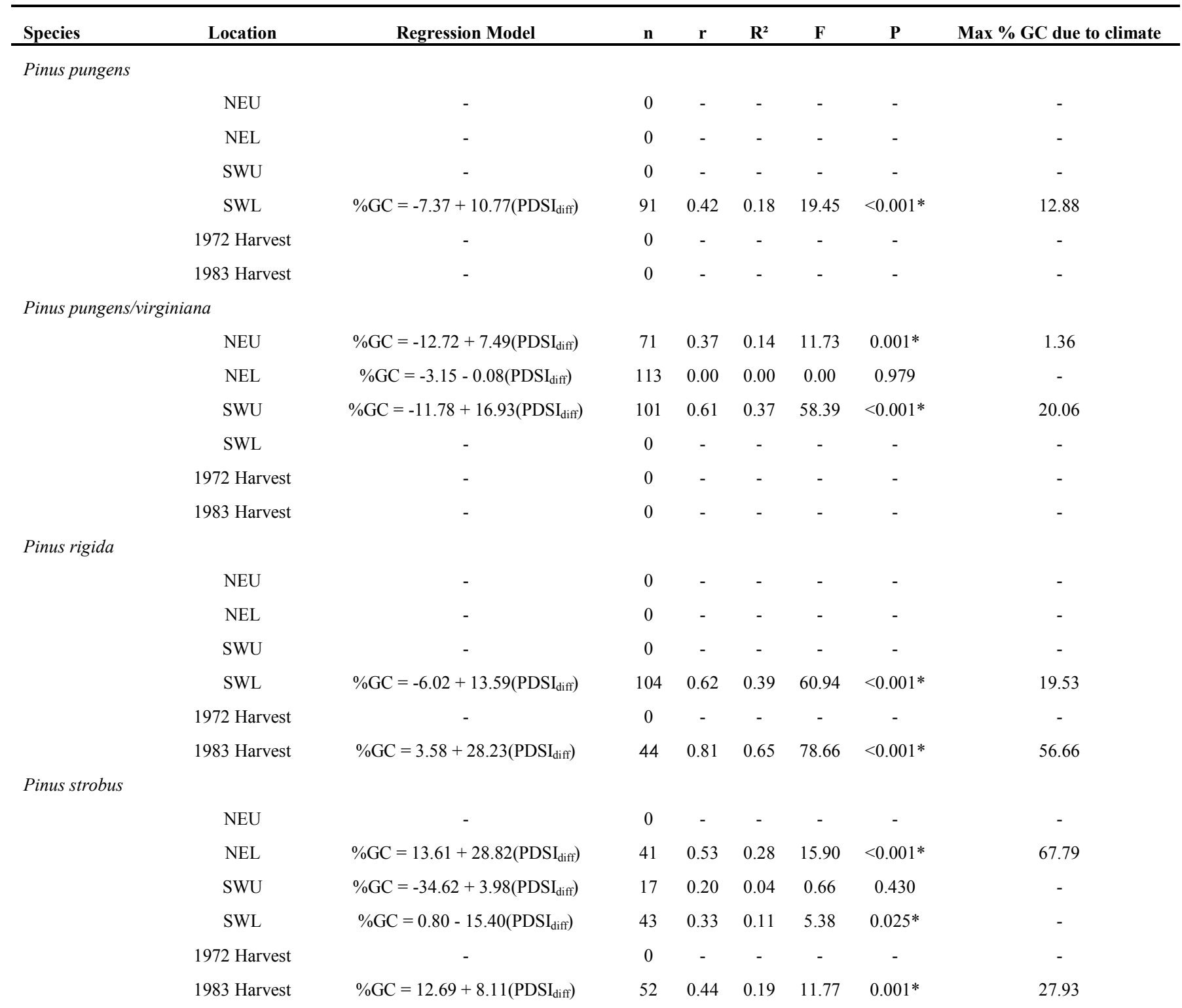




\begin{tabular}{|c|c|c|c|c|c|c|c|c|}
\hline & NEU & $\% \mathrm{GC}=-8.50+4.11\left(\mathrm{PDSI}_{\mathrm{diff}}\right)$ & 53 & 0.14 & 0.02 & 0.86 & 0.359 & - \\
\hline & NEL & $\% \mathrm{GC}=13.36+27.80\left(\mathrm{PDSI}_{\text {diff }}\right)$ & 85 & 0.44 & 0.19 & 19.19 & $<0.001^{*}$ & 65.62 \\
\hline & SWL & $\% \mathrm{GC}=-4.21+11.06\left(\mathrm{PDSI}_{\mathrm{diff}}\right)$ & 85 & 0.26 & 0.07 & 5.48 & $0.021 *$ & 16.58 \\
\hline & 1972 Harvest & - & 0 & - & - & - & - & - \\
\hline \multicolumn{9}{|l|}{ Quercus prinus } \\
\hline & NEU & $\% \mathrm{GC}=2.21+12.44\left(\mathrm{PDSI}_{\mathrm{diff}}\right)$ & 212 & 0.51 & 0.26 & 75.26 & $<0.001^{*}$ & 29.72 \\
\hline & NEL & $\% \mathrm{GC}=2.50+9.70\left(\mathrm{PDSI}_{\mathrm{diff}}\right)$ & 244 & 0.40 & 0.16 & 46.61 & $<0.001^{*}$ & 23.95 \\
\hline & SWU & $\% \mathrm{GC}=4.73+9.97\left(\mathrm{PDSI}_{\mathrm{diff}}\right)$ & 187 & 0.39 & 0.15 & 32.40 & $<0.001^{*}$ & 25.77 \\
\hline
\end{tabular}

\section{$\underline{\text { Major releases }}$}

The NEU area exhibited three non-climatic related major releases. These occurred in the decades of 1830, 1950, and 1990, respectively (Figure 3.8, bottom). Three major releases occurred in the NEL sampling area as well (Figure 3.9, bottom). In this area two major releases were detected in the decade of 1910, while the other occurred 1980 . The SWU area showed two major releases, one in 1950 and one in 1990 (Figure 3.10, bottom). Two major releases also occurred in the SWL sampling area (Figure 3.11, bottom). These were identified in the decades 1910 and 1940. None of the residuals from either of the harvest areas exhibited major releases.

\section{$\underline{\text { Moderate releases }}$}

Twelve non-climatic related moderate releases were detected in the NEU sampling area. These releases were detected in the decades of 1800 (1), 1840 (3), 1870 (2), 1910 (2), 
1940 (2), and 1990 (5) (Figure 3.8, bottom). Eleven moderate releases occurred in the NEL area: one each in the decades of $1840,1870,1880$, and 1980, two each in the decades of 1890 and 1920, and three in the decade of 1940 (Figure 3.9, bottom). The SWU area showed nine moderate releases. These were observed in the decades of 1820 (1), 1860 (1), 1890 (3), 1910 (3), and 1940 (1), respectively (Figure 3.10, bottom). The most moderate releases were found in the SWL area (Figure 3.11, bottom). Here, 16 releases were detected: one each in the decades of 1890, 1920, and 1950, two in the decade of 1980, five in the decade of 1940; and six in the decade of 1990. Two moderate releases were identified in the 1972 harvest area. These occurred in the decades of 1870 and 1990, respectively. Neither of these releases were indicative of the harvesting. One of the eastern white pine residuals showed a moderate release in the 1983 harvest. This release occurred in the decade of 1980 and is, therefore, a result of the harvesting.

\section{$\underline{\text { Small Releases }}$}

The NEU sampling area exhibited the highest number of small releases. Nineteen nonclimactic related small releases were detected in this area during the decades of 1790 (1), 1830 (1), 1860 (1), 1870 (3), 1890 (1), 1910 (3), 1940 (2), and 1990 (7) (Figure 3.8, bottom). Only seven moderate releases occurred in the NEL area: one each in the decades of 1716, 1790, 1800, 1820, and 1840, and two in the decade of 1910 (Figure 3.9, bottom). The SWU area showed 14 major releases. These were detected during the decades of 1840 (1), 1850 (1), 1910 (1), 1830 (2), 1930 (2), 1940 (2), 1990 (2), and 1870 (3), respectively one in 1950 and one in 1990 (Figure 3.10, bottom). Eighteen small releases occurred in the SWL sampling area (Figure 3.11, bottom). These were identified 
in the decades of 1900 (1), 1910 (3), 1920 (2), 1940 (5), 1980 (3), and 1990 (4). The chestnut oak residuals detected one small release in the 1972 harvest area during the decade of 1940. The eastern white pine residuals detected two small releases in the 1983 harvest area. One of these occurred in 1940, while the other was a result of the harvesting

\section{$\underline{\text { Major Disturbance Decades }}$}

Five major disturbances, the most of any area, were identified in the NEU sampling area. Two of these major disturbances occurred during the decades of 1840 and 1910 , coinciding well with cohorting (Figure 3.8). The other three major disturbances occurred in the decades of 1830,1870 , and 1990. Three major disturbances were identified in the NEL area. Again two of the major disturbances occurred during the decades of 1890 and 1910, corresponded with cohorting (Figure 3.9). The other major disturbance occurred in the decade of 1840. The SWU area also experienced two major disturbances that coincided with the cohorting around the turn of the twentieth century (Figure 3.10). Two more major disturbances were detected in this area, one each in the decades of 1830 and 1870. Only two major disturbances were identified in the SWL area. Again a major disturbance that occurred in 1910 corresponded with cohorting (Figure 3.11). The second major disturbance occurred in the decade of 1940.

\section{$\underline{\text { Frequency of Major Disturbances }}$}

Intervals of major disturbances ranged from 26 to 94 years (Table 3.5). 
Table 3.5. Return intervals (years) for major disturbances.

\begin{tabular}{|c|c|c|c|c|c|}
\hline \multirow{3}{*}{ Era } & \multicolumn{5}{|c|}{---------Sampling Stratum------- } \\
\hline & \multicolumn{4}{|c|}{--- } & \multirow[b]{2}{*}{ Mean } \\
\hline & $\underline{\text { NEU }}$ & $\underline{\text { NEL }}$ & $\underline{\text { SWU }}$ & $\underline{\text { SWL }}$ & \\
\hline Exploitation $(<1900)$ & 32 & 30 & 26 & 81 & 42 \\
\hline Modern $(>1900)$ & 47 & 94 & 94 & 47 & 71 \\
\hline
\end{tabular}

\section{Canopy Accession Trends}

All of the nineteen species/sampling stratum master chronologies were determined to be of gap origin.

\section{Tree-of-heaven Establishment}

Twenty-one areas where tree-of-heaven had ascended into the main canopy were identified while traversing the mountain (Figure 3.12). Approximately $71 \%$, or 15 , of these areas were within areas that had previously undergone harvesting. Four of the remaining six areas were around the base of the mountain near roads. Two of these were found along Forest Service Road 151B, located at the southeastern base of the mountain, which provided access to the two harvests in this area. The other two, found at the northwestern base of the mountain (Figure 3.12), were 3 and 78 meters away from Forest Service Road 151, respectively. Only two areas were found on the slopes of the mountain where harvesting had not occurred. One overstory tree-of-heaven was also encountered on one plot during the inventory (Figure 3.12). Both field observations and Figure 3.12 indicate that, other than in harvested areas, canopy level tree-of-heaven were restricted to moister riparian areas. 


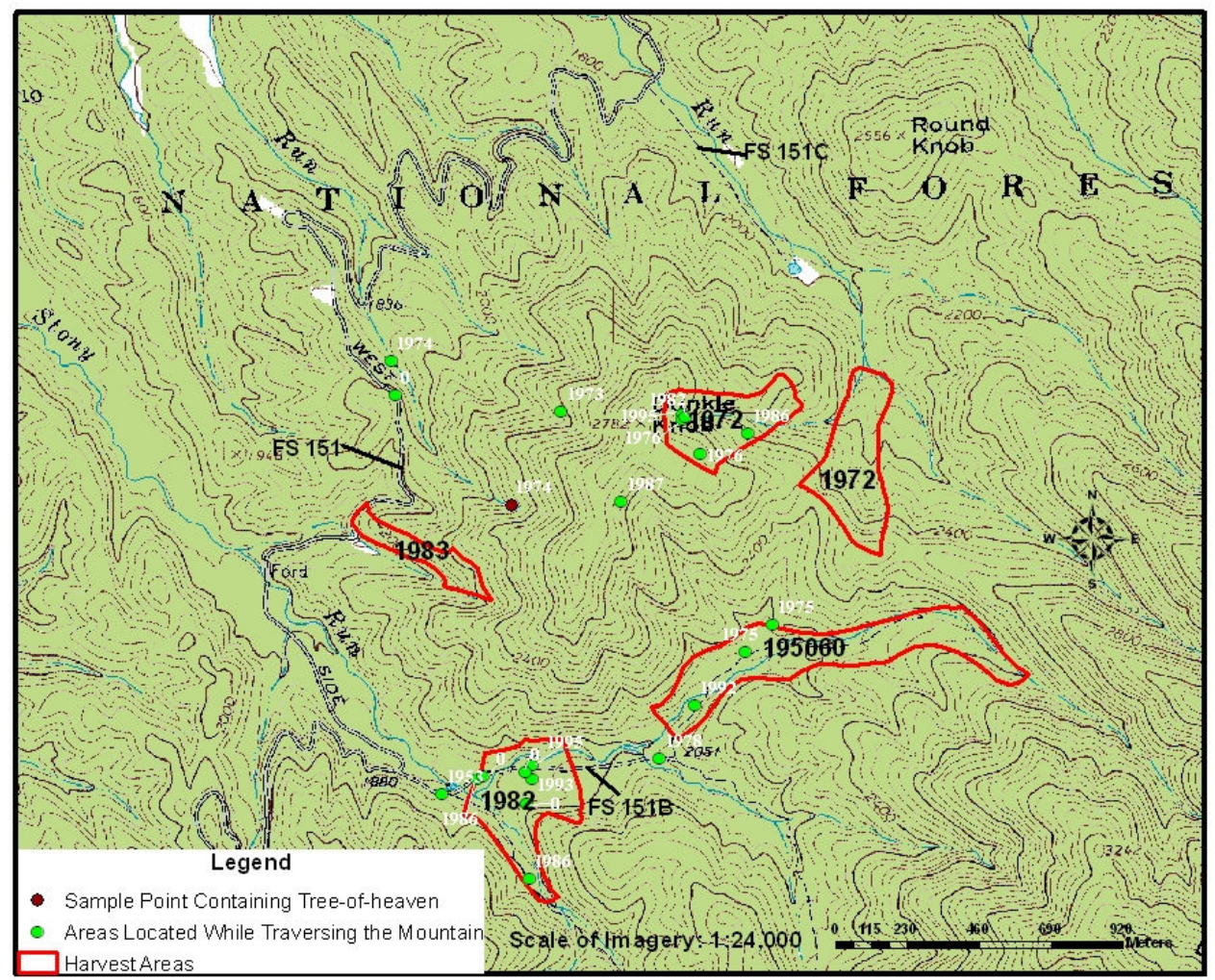

Figure 3.12. Establishment dates of the oldest tree in areas where tree-of-heaven has ascended into the main canopy. Because of their close proximity to other trees, increment cores were not extracted from areas labeled with a zero (four instances).

All of the oldest tree-of-heaven, with one exception, attained breast height after the harvesting occurred (Figure 3.12). The oldest tree of heaven is currently 55 years old (breast height attainment occurred in 1953) and has a DBH of $37 \mathrm{~cm}$. This individual is located at the southern base of Dunkle Knob, next to the gate for Forest Service Road 151B (Figure 3.12). 


\section{Discussion}

The results of this study represent some interesting findings and help to explain forest stand dynamics at the landscape level in the Dunkle Knob area.

\section{General Disturbance History}

The demographic and structural evidence indicate that all sampling areas on Dunkle Knob contain multiple cohorts and exhibit an uneven-aged structure. Tree ages currently range from 10 to 268 years. This age distribution and structure is an indication of multiple disturbances of varying intensities across the study area. The majority ( $81 \%)$ of the releases identified from $\% \mathrm{GC}$ data were small and moderate, which were likely a result of death or removal of one or two trees that neighbored a sample tree (Rentch and others 2002). Prior to fire exclusion in the study area, low-intensity fires could have caused some of the releases in localized areas.

Interestingly, all sampling areas experienced a major disturbance between the decades of 1890 and 1910. In all cases, these major disturbance events were consistent with age cohorting (Figures 3.8 - 3.11). The data suggested that this was the only area-wide disturbance event at the Dunkle Knob site over the 244 year period examined. Multiple species establishments occurred as a result. In the Appalachians, and throughout West Virginia, intensive harvesting practices, often followed by high-intensity fires, characterized the period from about 1880 to 1930 (Brose and others 2001). It can be assumed that, before it was purchased by the USDA Forest Service, the site was subject to exploitive logging. Some of the tremendously steep and rocky slopes of the Dunkle 
Knob study site were probably inaccessible for timber harvesting (J. Pomp, personal observation), and would have allowed for scattered pockets of residuals. Furthermore, in readily accessible areas, harvesting was likely targeted at higher value oak species and, if it existed with any importance on the site, American chestnut (Castanea dentata (Marsh.) Borkh.). Although the work of Braun (1950) indicates that the Dunkle Knob area is situated it what was once a region dominated by the oak-chestnut forest type, no remnant carcasses or stumps were encountered there in 2007 (J. Pomp, personal observation). In any case, the harvesting would have left only low value residuals, primarily chestnut oaks and a small number of table mountain and pitch pines. American chestnut would not have been able to re-establish because of the introduction of the lethal canker causing pathogen Cryphonectria parasitica (Murrill) Barr.

Nearly all of the serotinous-coned table mountain and pitch pines established just after the turn of the $20^{\text {th }}$ century, perhaps suggesting that a large fire followed the harvesting. Neither of these species, except for two cases on the SWL section of the mountain, established after the 1930's. For the most part, the only species that established after the decade of 1930 were chestnut oak, northern red oak, and Virginia pine. Eastern white pine was being planted by the USDA forest service on all areas, except in the NEU sampling area, from the 1940s through the 1980s.

Chestnut oak and pitch pine were the only species to exhibit releases from the combination of disturbances during the turn of the $20^{\text {th }}$ century. However, these were the only species which were alive prior to the disturbance. These trees would readily accept 
the extra resources provided by the harvesting, fire-induced mortality, and American chestnut decline. Average ages at release for these chestnut oaks ranged from 50 to 73 years. This was not surprising, given that other studies have documented the releases in oaks of similar ages (Rentch and Hicks 2003, Nowacki and Abrams 1997). Despite none of the chestnut oak samples exhibiting an understory origin-gap release canopy accession trend, this finding provides evidence of the ability of chestnut oak to endure lower positions in the canopy for extended time. Only one individual pitch pine showed a release around the turn of the $20^{\text {th }}$ century. As expected, this individual was young when it was released (10 years old).

Interestingly, only two of the decades denoted as major disturbance decades occurred after the 1910s. One occurred in the SWL sampling area in the decade of 1940 (Figure 3.11, bottom), while the other occurred during the 1990s in the NEU sampling area (Figure 3.8, bottom). The major disturbance in the SWL sampling area may have been a result of undocumented harvesting or fire. The major disturbance in the NEU sampling may have been a result of gypsy moth (Lymantria dispar L.) defoliation. During the late 1980s and early 1990s several major gypsy moth outbreaks occurred in West Virginia, especially in the eastern panhandle. According to USDA Forest Service annual defoliation data (USDA Forest Service, Northern Research Station 2007), it appears that defoliation could have occurred in the study area between 1985 and 1995. The fact that most of the releases during this decade were exhibited by the pines, and approximately 60 $\%$ of the chestnut oaks that did not show releases exhibited negative $\% \mathrm{GC}$, reinforces this hypothesis. 


\section{Canopy Accession Trends}

All of the species/sampling area master chronologies were determined to be of gap origin. This was expected because of the low tolerance to shade of the species examined. All of the yellow pines examined in this study are classified as shade intolerant (Hicks 1998, Williams \& Johnson 1990). Chestnut oak is classified as intermediate in shade tolerance, but is perhaps more shade intolerant than others in the white oak group (Hicks 1998).

\section{Disturbance Frequency}

Comparisons of major disturbance frequencies to frequencies found by Schuler and Fajvan (1999) and Nowacki and Abrams (1997) are irrelevant because their return intervals are based on stand-wide disturbances. Major disturbance frequencies, during both the exploitation and modern eras at the Dunkle Knob study site were much longer than the frequencies of multiple tree events found by Rentch and Hicks 2003. However, their study was conducted at the stand level and many more cores were extracted relative to the total size of the study site, which undoubtedly provided more precise results. On Dunkle Knob only one study area, or landscape level, disturbance was noted from the data, indicating a return interval of 244 years. An assessment of disturbances in different stands across the study site would provide a more comparable measure of disturbance frequencies.

Similar to the findings of Rentch and Hicks (2003) and Nowacki and Abrams (1997), the frequency of major disturbances was, on average, higher during the exploitation era (prior to 1900$)$ relative to the modern era. On average, disturbances occurred every 42 years in 
the exploitation era, compared to 71 years during the modern era. Based on a paired ttest, these values were not significantly different $(\mathrm{P}=0.162)$.

\section{Releases in Harvested Areas}

None of the residuals in the timber sale areas experienced major releases from the harvesting. All of the eastern white pine residuals in the 1983 harvest area however, exhibited either a small or moderate release following the harvesting. One of the goals of this clearcut with reserve trees harvest was to convert the area to eastern white pine. Harvesting records stated that "there was a good eastern white pine seed source to restock the stand." Although species of reserve trees are not listed in the records, clearly eastern white pine would have been the species of choice. These trees would have already been a member of the overstory, and were likely co-dominant or dominant. Thus, because they were not overtopped, a major release would not be expected from these individuals. Furthermore, these trees were, on average, thirty-three years of age at the time of harvesting. Eastern white pines less than 30 years old, with at least one-third of their height in live crown, respond well to release from competition. The ability to respond, however, declines proportionately with increasing age and decreasing crown length (Burns and Honkala 1990). Interestingly, regeneration and stand development in the 1983 harvest area did not go as the USDA Forest Service planned. That is, the area was not successfully converted to eastern white pine. The area is now dominated by "scrub" stands of Virginia pine that are at an average dominant height between 20 and 25 feet with sparse understory vegetation. Because the area was dominated by mature pitch pine prior to the harvest, it is evident that a clearcut did not successfully regenerate pitch pine 
either. Had a fire occurred following the clearcut, pitch pine regeneration may have been more successful.

\section{Tree-of-heaven Establishment}

Given that a sampling methodology designed to fully understand tree-of-heaven establishment was not employed in this part of the study, some areas where tree-ofheaven has reached the main canopy may have been missed. Nevertheless, the majority of the areas encountered were either in harvested areas or along roads (Figure 3.12). It should also be noted that there were other timber sales in close proximity to the study area which may have also influenced tree-of-heaven establishment. Tree-of-heaven is often associated with areas of disturbance relative to undisturbed areas (Call and Nilsen 2003, Huebner 2003). Furthermore, forest disturbances, natural or anthropogenic, generally decrease canopy cover and increase understory light, which, in turn, tends to promote invasion by exotic plant species (Bossard 1991, D'Antonio 1993, Hobbs and Huenneke 1992, Hutchinson and others 2004). Although it is well known that tree-ofheaven can tolerate a wide range of environmental conditions (Howard 2004), it appears that the extremely dry nature of the study site has limited its invasion into the overstory to disturbed portions of the mountain and, in some cases, in relatively undisturbed, moister riparian areas.

The oldest individual tree-of-heaven established before the initial timber extraction from the Dunkle Knob area in the 1950s. If this tree was a female, it could have provided seed for future cohorts following disturbance. Had the personnel that conducted the harvest 
noticed this individual and eliminated it, they may have prevented several of the other areas from becoming invaded. Seeds may have also been dispersed from other seed producing trees that were not encountered on or near the study site, as tree-of-heaven seed can be dispersed as far as 200 meters from the female parent (Kota 2005).

\section{Conclusions and Management Implications}

The oak-pine forest type in the study area was presumably converted from an oakchestnut forest type as a result of a combination of anthropogenic and natural disturbances in the early $20^{\text {th }}$ century. The results indicate that the disturbance regime that followed this conversion is not sufficient for the serotinous-coned yellow pines to maintain their role as an important part of the overstory at Dunkle Knob. That is, neither table mountain pine or pitch pine are not recruiting well in the understory (Table 3.2). The loss of fire as a disturbance agent in 1923 likely played a key role in this developmental pathway. Post-1930 species establishment indicate that oaks have been slowly gaining importance in the study area. However, considering the economic and wildlife value of oak species, as well as the current widespread oak regeneration problem throughout the Appalachians, this trend does not rectify some management objectives.

Tree-of-heaven is one of the most problematic exotic invasive species in the eastern US. In addition to its highly invasive nature, it also possesses allelopathic properties (Heisey 1996). Native understory plants, as well as the benefits they provide (e.g. biodiversity, food for wildlife), are in danger of being severely impacted by abundant tree-of-heaven vegetative reproduction (root suckers) in localized areas around the main stems that have 
ascended into the main canopy. Furthermore, Huebner (2006) suggests that, if large seed producing females exist, tree-of-heaven may increase in abundance with repeated burning. Managers should attempt to eradicate these tree-of-heaven "hot spots" prior to applying the next burn. Effective chemical control methods are available for controlling this unwanted exotic invader (Eck 2005). Pre-fire control of tree-of-heaven would aim to make the forest more resilient to further invasion and reduce the likelihood of post-fire establishment. 


\section{Literature Cited}

Abrams, M. D. 1992. Fire and the development of oak forests. Bioscience. 42(5): 346-353.

Bossard, C. C. 1991. The role of habitat disturbance, seed predation, and ant dispersal on establishment of the exotic shrub Cytisus scoparius in California. American Midland Naturalist. 126(1): 1-13.

Braun, E.L. 1950. Deciduous Forests of Eastern North America. New York, NY: Macmillan.

Brose, P. H.; Schuler, T. M.; Van Lear, D; Berst, J. 2001. Bringing fire back: the changing regimes of the Appalachian mixed-oak forests. Journal of Forestry. 99(11): 30-35.

Brose, P. H.; Waldrop, T. A. 2006a. Fire and the origin of table mountain pine - pitch pine communities in the southern Appalachian Mountains, USA. Canadian Journal of Forest Research. 36: 710-718

Brose, P. H.; Waldrop, T. A. 2006b. Changes in the disturbance regime of upland yellow pine stands in the southern Appalachian Mountains during the $20^{\text {th }}$ century. USDA Forest Service, Gen. Tech. Rep. SRS-92.

Burns, R. M.; Honkala, B. H. 1990. Silvics of North America: Volume 1. Conifers. Washington, DC: USDA Forest Service, Agriculture Handbook 54.

Call, L. J.; Nilsen, E. T. 2003. Analysis of spatial patterns and spatial association between the invasive exotic tree-of-heaven (Ailanthus altissima) and the native black locust (Robinia pseudoacacia). The American Midland Naturalist. 150(1): $1-14$.

Core, E.L. 1966. Vegetation of West Virginia. Parsons, WV: McClain Printing Company.

D’Antonio, C. M. 1993. Mechanisms controlling invasion of coastal plant communities by the alien succulent Carpobrotus edulis. Ecology. 74: 83-95.

D’Antonio, C. M.; Vitousek, P. M. 1992. Biological invasions by exotic grasses, the grass/fire cycle, and global change. Annual Review of Ecological Systems. 23: 63-87.

Eck, W. E. 2005. Investigating treatment windows for effective and environmentally sound herbicide applications for controlling tree-of-heaven. Morgantown, WV: West Virginia University. 61p. M.S. Thesis. 
Estepp, R. 1992. Soil Survey of Pendleton County, West Virginia. U.S. Soil Conservation Service.

Grissino-Mayer, H. D.; Holmes, R. L.; Fritts, H. C. 1997. The international tree-ring data bank program library version 2.1 user's manual. Laboratory of Tree-Ring Research, University of Arizona, Tuscon, AZ.

Harmon, M. E. 1982. Fire history of the westernmost portion of Great Smoky Mountains National Park. Bulletin of the Torrey Botanical Club. 109: 74-79.

Heisey, R. M. 1996. Identifications of an allelopathic compound from Ailanthus altissima (Simaroubaceae) and characterization of its herbicidal activity. American Journal of Botany. 83: 192-200.

Hicks, R. R., Jr. 1998. Ecology and Management of Central Hardwood Forests. New York, NY: John Wiley \& Sons, Inc.

Hobbs, R. J.; Huenneke, L. F. 1992. Disturbance, diversity, and invasion: implications for conservation. Conservation Biology. 6(3): 324-337.

Howard, J. L. 2004. Ailanthus altissima. In: Fire Effects Information System. http://www.fs.fed.us/database/feis/. USDA Forest Service, Rocky Mountain Research Station, Fire Sciences Laboratory (producer). [Date Accessed: March 2, 2008].

Huebner, C. D. 2003. Vulnerability of oak-dominated forests in West Virginia to invasive exotic plants: temporal and spatial patterns of nine exotic species using herbarium records and land classification data. Castanea. 68(1): 1-14.

Huebner, C. D. 2006. Fire and invasive exotic plant species in eastern oak communities: an assessment of current knowledge. In: Dickinson, M. B., ed. 2006. Fire in eastern oak forests: delivering science to land managers, proceedings of a conference. USDA Forest Service Gen. Tech. Rep. NRS-P-1.

Hutchinson, T. F.; Rebbeck, J.; Long, R. 2004. Abundant establishment of Ailanthus altissima (tree-of-heaven) after restoration treatments in an upland oak forest. In: Yaussy, D. A.; Hix, D. M.; Long, R. P.; Goebel, C. P., eds. Proceedings of the $14^{\text {th }}$ Central Hardwoods Forest Conference. USDA Forest Service, Gen. Tech. Rep. NE-316.

Kota, N. L. 2005. Comparative seed dispersal, seedling establishment, and growth of exotic, invasive Ailanthus altissima (Mill.) Swingle and native Liriodendron tulipifera (L.). Morgantown, WV: West Virginia University. 108p. M.S. Thesis.

Lorimer, C. G. 1985. Methodological considerations in the analysis of forest disturbance history. Canadian Journal of Forest Research. 15: 200-213. 
Lorimer, C. G.; Frelich, L. E. 1989. A methodology for estimating canopy disturbance frequency and intensity in dense temperate forests. Canadian Journal of Forest Research. 19: 651-663.

Marsh, M. A. 2005. Floristic dynamics of Appalachian pine-oak forests over a prescribed fire chronosequence. Morgantown, WV: West Virginia University. 275p. M.S. Thesis.

Maxwell, R. S. 2006. Establishing a historic benchmark for rimrock pine communities at New River Gorge National River, West Virginia. Morgantown, WV: West Virginia University. 97p. M.S. Thesis.

Mlot, C. 2003. Invasive Species West Virginia. Cambridge, MA: Union of Concerned Scientists.

Nowacki, G. J.; Abrams, M. D. 1992. Community, edaphic, and historical analysis of mixed oak forests of the Ridge and Valley Province in central Pennsylvania. Canadian Journal of Forest Research. 22: 790-800.

Nowacki, G. J.; Abrams, M. D. 1997. Radial-growth averaging criteria for reconstructing disturbance histories from pre-settlement origin oaks. Ecological Monographs. 67(2): 225-249.

Rentch, J. S.; Fekedulegn, D.; Miller, G. W. 2002. Climate, canopy disturbance, and radial growth averaging in a second-growth mixed-oak forest in West Virginia, U.S.A. Canadian Journal of Forest Research. 32: 915-927.

Rentch, J. S.; Hicks, R. R, Jr. 2003. Canopy disturbance intervals, early growth rates, and canopy accession trends of oak-dominated old-growth forests. In: Van Sambeek, J. W.; Dawson, J. O.; Ponder, F, Jr.; [and others]., eds. Proceedings of the $13^{\text {th }}$ Central Hardwood Forest Conference. USDA Forest Service, Gen. Tech. Rep. NC-234.

Schuler, T. M.; Fajvan, M. A. 1999. Understory tree characteristics and disturbance history of a central Appalachian forest prior to old-growth harvesting. USDA Forest Service, Res. Pap. NE-710.

Schuler, T. M.; McClain, W. R. 2003. Fire history of a Ridge and Valley oak forest. USDA Forest Service, Res. Pap. NE-724.

Shumway, D. L.; Abrams, M. D.; Ruffner, C. M. 2001. A 400-year history of fire and oak recruitment in an old-growth forest in western Maryland, U.S.A. Canadian Journal of Forest Research. 31: 1437-1443.

Smith, D. M.; Larson, B. C.; Kelty, M. J.; Ashton, P.M.S. 1997. The Practice of 
Silviculture: Applied Forest Ecology. Hoboken, NJ: John Wiley \& Sons, Inc.

Southern Appalachian Man and the Biosphere (SAMAB). 1996. The southern Appalachian assessment terrestrial technical report. USDA Forest Service, Rep. 5.

Stokes, M. A.; Smiley, T. J. 1968. An Introduction to Tree-Ring Dating. Chicago, IL: University of Chicago Press.

Sutherland, E. K.; Grissino-Mayer, H. D.; Woodhouse, C. A.; [and others]. 1995. Two centuries of fire in a southwestern Virginia Pinus pungens community. In Proceedings: IUFRO Conference on Inventory and Management in the Context of Catastrophic Events: Altered States of the Forest, University Park, PA. 21-24 June 1993. Pennsylvania State University, Center of Statistical Ecology and Environmental Statistics, University Park, PA.

USDA Forest Service, Northern Research Station. 2007. Annual Gypsy Moth Defoliation. Version 1 (vector digital data). Available online: http://www.fs.fed.us/ne/morgantown/4557/AFPE/data.htm. [Date Accessed: April 15, 2008].

Vitousek, P. M.; Walker, L. R. 1989. Biological invasions by Myricacia faya in Hawaii: plant demography, nitrogen fixation, ecosystem effects. Ecological Monographs. 59: $247-265$

Waldrop, T. A.; Mohr, H. H.; Brose, P. H. 2006. Early dynamics of table mountain pine stands following stand-replacement prescribed fires of varying intensity. USDA Forest Service, Gen. Tech. Rep. SRS-92.

Welch, N. T.; Waldrop, T. A.; Buckner, E. R. 2000. Response of southern Appalachian table mountain pine (Pinus pungens) and pitch pine (P. rigida) stands to prescribed burning. Forest Ecology and Management. 136: 185-197.

Williams, C.E. 1998. History and status of table mountain pine-pitch pine forests of the southern Appalachian mountains (U.S.A.). Natural Areas Journal. 18: 81-90.

Williams, C. E.; Johnson, C. W. 1990. Age structure and the maintenance of Pinus pungens in pine-oak forests of southwestern Virginia. American Midland Naturalist. 124(1): 130-141.

Yarnell, S. L. 1998. The southern Appalachians: a history of the landscape. USDA Forest Service, Gen. Tech. Rep. SRS-18. 


\section{CHAPTER 4}

Investigating the Relationship between Bole Scorch Height and Fire Intensity Variables in the Ridge and Valley Physiographic Province, West Virginia 


\begin{abstract}
Prescribed fires are carried out on the George Washington National Forest (GWNF) to promote long-term resource and social values, including tree regeneration, improving wildlife habitat and aesthetics, and maintenance of low woody fuel loading. Prescribed fire programs have increased on the GWNF over the past twenty years. Although prescribed fire is widely used on the GWNF, methods and techniques for monitoring fire behavior are still in the early stages of development. As part of a larger study to assess the effects of prescribed fire on exotic invasive species in the Ridge and Valley of eastern West Virginia, I used simple linear correlation and regression analysis to investigate the relationships between plot-level three-year post-fire bole scorch height parameters, fire temperature as estimated by thermocouple probes, litter consumption, and sapling mortality to better understand and predict fire effects in mixed-oak and oak-pine forests. I collected information on these parameters as they were observed on 36 research plots in an area where a prescribed fire had been applied in the Ridge and Valley. The prescribed burn totaled 313.6 ha and was conducted in March 2004. Neither overstory or sapling bole scorch height variables were significantly related to thermocouple temperature measurements recorded at five locations on a southwest facing slope $(\alpha=0.05)$. The sum of the sapling scorch heights was significantly related to litter consumption, but only accounted for $11 \%$ of the variation. However, all bole scorch height variables were significantly related to sapling mortality one growing season after the fire. This further illustrates the usefulness of scorch height as an estimator of relative fire intensity, and provides a useful prediction model for xeric mixed-oak and oak-pine fire managers.
\end{abstract}




\section{Introduction}

Prescribed fire is primarily used on the George Washington National Forest (GWNF) to manage areas unsuitable for timber production. These sites are often characterized by infertile soils, steep/rocky slopes, non-commercial/low-value species mixtures, or pineoak stands in general (United States Department of Agriculture (USDA) Forest Service 1993). The fires are applied to promote long-term resource and social values like maintenance of low woody fuel loading, aesthetics, tree regeneration and increased abundance of understory plants that are valuable for wildlife forage, such as blueberries (Vaccinium spp.), huckleberry (Gaylussacia baccata (Wangenh.) K. Koch), scrub oak (Quercus ilicifolia Wangenh.), and various grasses. Since the mid- to late-1980s, the extent of these fires has increased quite dramatically (Figure 4.1). In the decade of 1980, GWNF managers treated, on average, 37.2 hectares/year, compared to 877.2 hectares/year in the 1990s and 2,097.0 hectares per year this decade. That equates to an astounding $2,240 \%$ increase from the 1980 s to the $1990 \mathrm{~s}$, and a $140 \%$ increase from the 1990 s to the 2000 s, respectively.

Several studies have examined fire behavior in a number of various regions. However, fire behavior-related studies in the Appalachian region are limited (Franklin and others 1997, Clinton and others 1998, Vose and others 1999, Iverson and others 2004). Although prescribed fire is widely used on the GWNF, methods and techniques for monitoring fire behavior are still in the early stages of development. 


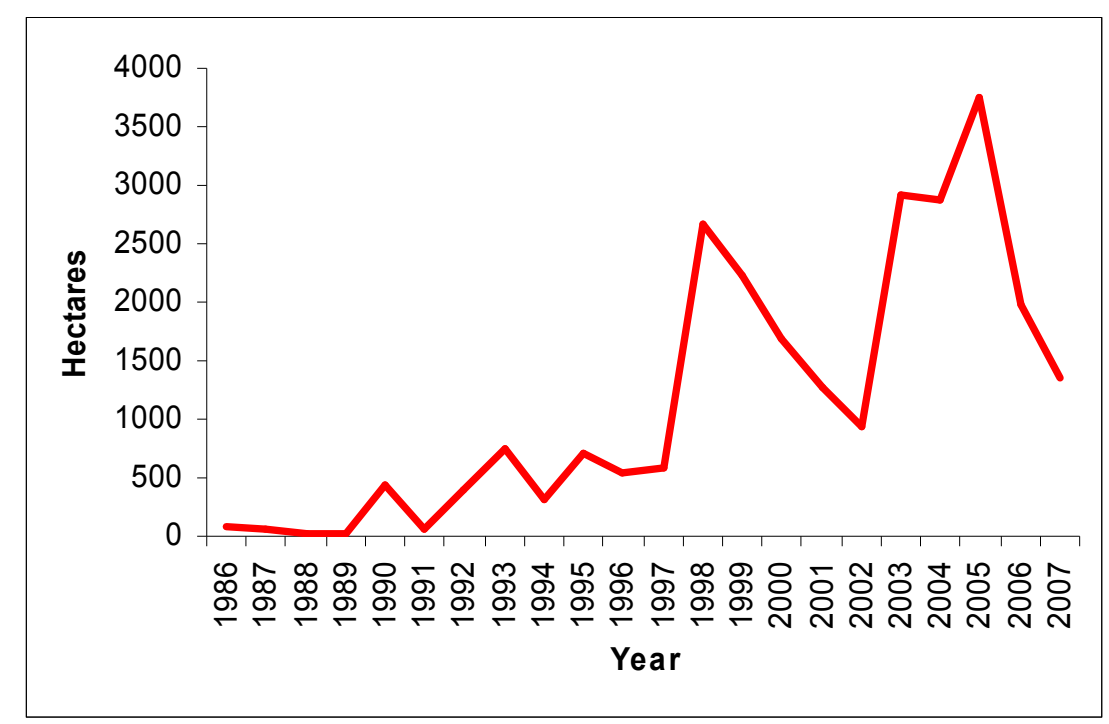

Figure 4.1. Area treated with prescribed fire by year on the GWNF.

Bole scorch height, otherwise known as stem-bark char or height of bole blackening, variables have been proven to be significant predictors of post-fire mortality in various forest types (Loomis 1973, Wyant and others 1986, Regelbrugge and Conrad 1993, Regelbrugge and Smith 1994). It has also been proven to be highly correlated with areal percent canopy scorch and top-kill of individual trees (Regelbrugge and Smith 1994). Although bole scorch height underestimates flame length in prescribed burns (Cain 1984), these findings indicate that it can be used to estimate relative fire intensity at the stand-level.

As part of a larger study to assess the effects of prescribed fire on exotic invasive species in eastern West Virginia, I investigated the relationship between plot-level three-year post-fire bole scorch height parameters (independent variables) and other fire intensity variables to better understand and predict fire effects in xeric mixed-oak and oak-pine forests. A better understanding of the role of fire in determining the structure and 
composition of xeric mixed-oak and oak-pine forests of the Ridge and Valley

Physiographic Province will enhance management efforts to sustain these forests.

In this chapter, I focus on the relationships between measured variables and the usefulness of these parameters for predicting changes in stand structure. Three relationships are evaluated, including; (1) litter consumption as a function of scorch height, (2) thermocouple estimated fire temperature as a function of scorch height, and (3) sapling mortality as a function of scorch height. The intent of this analysis is to evaluate whether these quick, simple, and inexpensive field measurements can help characterize prescribed fire behavior and its short-term effects on forest structure and composition. I expect increasing litter consumption, thermocouple temperature, and sapling mortality with increasing bole scorch height.

\section{Methods}

\section{Study Site}

This study was conducted at Dunkle Knob located on the North River Ranger District

(formerly the Dry River Ranger District) of the GWNF, Pendleton County, West Virginia $\left(38^{\circ} 37^{\prime} \mathrm{N}, 79^{\circ} 14^{\prime} \mathrm{W}\right)$. The study area encompassed 313.6 ha and is composed of xeric mixed-oak and oak-pine communities. The area is within the Ridge and Valley Physiographic Province and is in the rain-shadow of the Allegheny Mountains, which causes a climate that is much drier than the rest of the state (Core 1966). The area is characterized by an average annual precipitation of $82 \mathrm{~cm}$, an average annual temperature of $10.9^{\circ} \mathrm{C}$, and a growing season of approximately 144 days (Estepp 1992). Forests of 
the region can be characterized as being part of the former oak-chestnut cover type (Braun 1950).

The topography is highly dissected with slopes ranging from 6 to $70 \%$. Elevation ranges from 573 to $848 \mathrm{~m}$. The predominant soil type is of the Berks-Weikert association. They are loamy-skeletal, mixed, Dystrochrepts formed from acidic shale, siltstone, or sandstone bedrock. The soils are droughty, infertile, and often contain numerous rock outcroppings (Estepp 1992).

The Dunkle Knob area was purchased by the USDA Forest Service in 1923. There have been no documented fires in the Dunkle Knob area from its purchase date up to the time of the prescribed fire (Marsh 2005). Dunkle Knob was treated with a prescribed fire on March 29, 2004. Air temperatures ranged from $11^{\circ}-21^{\circ} \mathrm{C}$ and relative humidity ranged from 29 to $76 \%$. Winds were primarily from the northwest and southeast at a speed of 2$10 \mathrm{Km} / \mathrm{H}$. The interior of the mountain was ignited in a northeast-southwest pattern from top to bottom by a helicopter dropping delayed aerial ignition devices. The prescribed fire perimeter was established using existing roads and limited new fire line construction as fire breaks. This perimeter area was ignited by ground personnel using drip torches (Marsh 2005).

Pre-fire (2003) total basal area for the overstory (trees $\geq 12.7 \mathrm{~cm}$ diameter at breast height (DBH)) averaged $20.8 \mathrm{~m}^{2} / \mathrm{ha}$, and increased to $23.0 \mathrm{~m}^{2} /$ ha by 2007 . Chestnut oak 
(Quercus prinus L.), table mountain pine (Pinus pungens Lamb.), and Virginia pine

(Pinus virginiana P. Mill.) made up $66.5 \%$ of the overstory basal area in 2007.

\section{Field Methods}

Thirty-six circular 0.05 ha overstory plots were randomly established at the Dunkle Knob study site during the summer of 2003 (pre-fire). Eighteen plots were randomly established on northeast- $\left(315-235^{\circ}\right)$ and southwest- (236-314 $)$ facing slopes. Within each aspect class, nine plots each were established above and below $748 \mathrm{~m}$ elevation (see Marsh 2005 for complete sampling experimental design). To aid in future relocation, sample points were located with a Global Positioning System (GPS) and a piece of steel rebar was driven into the ground at plot center. Also, plot boundaries were flagged.

Each plot was inventoried in the summers of 2003 (pre-fire), 2004 (three to four months post-fire) and 2007, three full growing seasons after the fire. All overstory trees (DBH > $12.7 \mathrm{~cm}$ ), both living and dead, were tallied. Each tree was identified to species (although a small number of dead trees could not be positively identified), and crown class was recorded. Stem diameter was measured to the nearest $0.1 \mathrm{~cm}$ using a diameter tape. During the 2007 inventory, bole scorch height, defined as height of the highest point of bole blackening on the uphill face of the tree (Regelbrugge and Smith 1994), was measured to the nearest $15 \mathrm{~cm}$ using a height pole. The sapling layer (all trees $2.54 \mathrm{~cm} \leq$ $\mathrm{DBH} \leq 12.6 \mathrm{~cm}$ ) was sampled using a circular 0.01 ha plot located at the center of each overstory plot $(\mathrm{n}=36)$. All saplings were identified to species and DBH. Bole scorch height on saplings was also recorded as described above. 
Also within each overstory plot, $1 \mathrm{~m}^{2}$ circular plots were established at $12.06 \mathrm{~m}$ from the overstory plot center in each of the four cardinal directions $(n=144)$. These were primarily for understory vegetation measurements; however, litter layer (Oi) depth was measured to the nearest $0.1 \mathrm{~cm}$ at the west end of each plot using a ruler in 2003 and 2004.

On five south-facing overstory plots, $9.14 \mathrm{~m}^{2}$ square sampling plots were established. On these plots, the prescribed fire itself was monitored using a network of thermocouple probes. These sample points were selected due to logistical considerations and the expectation that the prescribed fire would be the most intense on southerly aspects (Marsh 2005). At the corners and at the center of these square plots, $25 \mathrm{~cm}$ thermocouple probes were installed and $\mathrm{HOBO}^{\circledR}$ data loggers (Onset Computer Corporation, Bourne, MA) were buried just below the surface in a manner similar to that of Iverson and others (2004) and set to record thermocouple temperature at four second intervals the day of the prescribed fire. All data loggers were collected immediately following the treatment. It is well known that Type $\mathrm{K}$ thermocouple probes cannot record flame or air temperature around the probe during a prescribed fire because of the lag time of the probes and the relatively short duration of the most intense heating (Iverson and others 2004). However, it was my desire to use a small sample of thermocouple probe temperature data to characterize fire behavior on what I believed would be the most intense area of the fire, and to assess its usefulness for predicting fire effects. 


\section{Analytical Methods}

Pre- and post-fire litter depth (LD) measurements were averaged for each overstory plot $(n=4)$, and litter consumption was quantified by the average percentage change in these values $(\mathrm{n}=36)$. Litter consumption was calculated using the equation:

$$
\text { Litter Consumption }=\left(\frac{\left(L D_{\text {post }}-L D_{\text {pre }}\right)}{L D_{\text {pre }}}\right) * 100
$$

Scatter plots were used to graphically examine all relationships for linearity, as well as any potential non-linear relationships. Following graphical examination, simple linear correlation and regression analysis were performed to examine the relationship between litter consumption (dependent) and both overstory and sapling bole scorch height measures (mean and sum) (independent) for all plots. The sum of hardwood tree heights is commonly used as a measure of hardwood competition in young southern pine plantations. Similarly, I tested the sum of the scorch heights as an independent variable that combines the number of stems scorched and degree of charring to determine its usefulness as a surrogate for fire behavior.

The analysis was also performed separately for mostly scorched plots. In this study, mostly scorched plots are defined as plots in which $\geq 50 \%$ of the overstory trees were scorched. This separate analysis was performed to reduce within-plot scorch height variability. This method reduced this variability considerably in a pilot study of plot level bole scorch height against temperature sensitive paint used to estimate fire 
temperature from another prescribed fire in a mixed-oak stand in the Ridge and Valley Province ${ }^{2}$.

Linear correlation and regression were also used to examine the relationships between recorded thermocouple temperature (dependent) and bole scorch height parameters.

To better understand how post-fire stand structure attributes were influenced by surrogates of fire intensity, a third correlation/regression analysis was performed to observe how the change in the number of understory living saplings (percent mortality) varied with plot-level bole scorch height variables.

All statistical analyses were performed using SAS 9.1 software (SAS Institute, 2003), with significance determined at an $\alpha=0.05$. Effects of independent variables were assessed using the General Linear Model (GLM) procedure. Mean comparisons were evaluated with paired t-tests. The DFFITS procedure was used to examine plot data and identify influential observations (outliers). The SAS DFFITS procedure identified one plot as a statistical outlier. Therefore this plot was removed from the analyses. Interestingly, this was the only plot in the study area in which the overstory was dominated by pitch pine ( $>50 \%$ of the overstory basal area). Both average and sum of the scorch heights on this plot were much greater than on others.

\footnotetext{
${ }^{2}$ Data on file with the USDA Forest Service, Northern Research Station, Parsons, WV.
} 


\section{Results and Discussion}

\section{Litter Consumption}

Immediately following the prescribed fire, litter depth differed significantly from pre-fire conditions. The fire, on average, resulted in a $49.5 \%$ decrease in litter depth $(2.14 \mathrm{~cm}$ in 2003 compared to $1.08 \mathrm{~cm}$ in 2004). Average three year post-fire bole scorch height variables were significantly different between the overstory and understory strata based on paired t-tests. Loucks and others (2004) found that mean scorch heights increased with larger diameter classes in an Appalachian hardwood forest in Kentucky. Similarly, our study showed means that were significantly higher for the overstory stratum (Table 4.1). These scorch height differences suggest that researchers or managers interested in measuring scorch height should also stratify their sample by these forest layers.

Table 4.1. Average scorch height parameters (cm) by stratum.

\begin{tabular}{llc}
\hline Stratum & $\underline{\text { Mean }}$ & $\underline{\text { Sum }}$ \\
Overstory & 56.01 & 1450.41 \\
Sapling & 38.37 & 286.08 \\
\hline
\end{tabular}

Both means were significantly different between strata at $\alpha=0.05$.

Neither of the overstory stratum independent variables (mean and sum of the scorch heights) could effectively predict litter consumption (Table 4.2). The sum of the sapling scorch heights, however, proved to be a significant litter consumption predictor. Unfortunately, the model can only account for $11 \%$ of the variation in litter consumption. More intricate fuel measurements (e.g. fuel transects and moisture content) may show stronger relationships to the measured variables than simple percentage change 
in litter depth. Mass changes in the litter layer may alter ecosystem functions, but can be time consuming to measure. Developing efficient methods for estimating such changes would be helpful to forest managers. The fire effects on the litter layer were similar to the work of Brown and others (1991) and Elliot and others (2002).

\begin{tabular}{|c|c|c|c|c|}
\hline Stratum & Variable & $\mathrm{r}$ & $\mathrm{R}^{2}$ & $\mathrm{P}$ \\
\hline \multirow[t]{2}{*}{ Overstory } & Mean & 0.20 & 0.04 & 0.253 \\
\hline & Sum & 0.14 & 0.02 & 0.407 \\
\hline Sapling & $\begin{array}{l}\text { Mean } \\
\text { Sum }\end{array}$ & $\begin{array}{l}0.29 \\
0.33\end{array}$ & $\begin{array}{l}0.09 \\
0.11\end{array}$ & $\begin{array}{c}0.128 \\
0.049^{*}\end{array}$ \\
\hline
\end{tabular}

*Indicates significance at $\alpha=0.05$

Contrary to my expectations, the results were similar when the analysis was restricted to plots in which greater than $50 \%$ of the trees were scorched (Table 4.3). Even though I found a positive linear correlation, there was little evidence that any measure of scorch height was a useful predictor of litter consumption, due to the large amount of unexplained variation in the model. The most promising explanatory variable in this restricted analysis was the sum of the sapling scorch heights $(\mathrm{P}=0.060)$. I suspect that the weak correlation between these variables is due to the litter layer itself. That is, given the thin pre-fire litter layer $(2.14 \mathrm{~cm}$ on average), plots experiencing even the modest intensity would likely lose nearly their entire litter layer. Future efforts to develop easy to measure predictor variables to estimate litter consumption should narrow the ecological amplitude of the explanatory variables to potentially improve model performance. 
Table 4.3. Relationships between bole scorch height variables $(\mathrm{cm})$ and litter consumption $(\%)$ for plots

with $\geq 50 \%$ of the trees scorched $(n=18)$.

\begin{tabular}{lcccc}
\hline Stratum & Variable & $\mathrm{r}$ & $\mathrm{R}^{2}$ & $\mathrm{P}$ \\
\hline Overstory & Mean & 0.22 & 0.05 & 0.393 \\
& Sum & 0.10 & 0.01 & 0.634 \\
\hline Sapling & Mean & 0.35 & 0.12 & 0.168 \\
& Sum & 0.45 & 0.20 & 0.060 \\
\hline
\end{tabular}

\section{Thermocouple Temperature}

Although I found a general positive relationship between scorch height and thermocouple temperature, there was little evidence of a useful predictive relationship (Table 4.4).

When compared to litter consumption predictions, $\mathrm{R}^{2}$ values were, in general, higher for overstory scorch height based thermocouple temperature predictions. However, this larger value is likely due to the fact that only a small number of points could be used to examine the relationships between scorch height and thermocouple temperature.

Table 4.4.--Relationships between bole scorch height variables $(\mathrm{cm})$ and fire temperature $\left({ }^{\circ} \mathrm{C}\right)$ for five plots fitted with thermocouples.

\begin{tabular}{lcccc}
\hline Stratum & Variable & $\mathrm{r}$ & $\mathrm{R}^{2}$ & $\mathrm{P}$ \\
\hline Overstory & Mean & 0.62 & 0.39 & 0.264 \\
& Sum & 0.70 & 0.50 & 0.184 \\
\hline Sapling & Mean & 0.04 & 0.002 & 0.940 \\
& Sum & 0.14 & 0.02 & 0.823 \\
\hline
\end{tabular}

It should be emphasized that the thermocouple temperatures used in the analysis were the average of five thermocouple probes on each plot. Due to the limitation of such instrumentation, averaging probe temperature may mask significant spatial variability among fire intensity throughout the sample area, ultimately weakening the relationship. 
Despite the results, I speculate that useful predictive relationships between thermocouple probe temperatures and fire effects could be developed if more spatially limited procedures were utilized. Employing more intensive sampling would likely limit bias and produce more indicative and statistically significant results as well. However, the time consuming nature of using thermocouple probes combined with their potentially limited spatial extrapolations may ultimately restrict their usefulness by managers.

\section{Sapling Mortality}

Total pre-fire number of living saplings averaged 1000 trees per hectare (TPH), compared to $725 \mathrm{TPH}$ in 2004. These values were significantly different $(\mathrm{P}<0.001)$. Chestnut oak, pignut hickory (Carya glabra (P. Mill.) Sweet), Virginia pine, and striped maple (Acer pensylvanicum L.) made up 53.7\% of the number of saplings in 2007.

There was ample evidence of a relationship between scorch height and sapling mortality induced by the prescribed fire. All overstory and sapling layer scorch height variables were significant predictors of sapling mortality (Table 4.5). Future analyses should assess species specific predictive relationships. Average overstory bole scorch height provided the strongest relationship and accounted for $63 \%$ of the variation in sapling mortality (Figure 4.2). By contrast, Regelbrugge and Smith (1994) found that the average scorch height accounted for $96 \%$ of the variation in the percentage of the number of fire-killed trees. However, their study was conducted in the aftermath of a 1900 ha wildfire which exhibited greater amplitude in scorch height and fire severity than the Dunkle Knob prescribed fire I monitored. They also chose stands with both low and 
high fire severity to provide a wide range of fire intensity and subsequent effects. My results further illustrate the usefulness of this relationship even when conditions are much more homogenous.

Table 4.5. Sapling mortality (\%) models and associated statistics.

\begin{tabular}{ccccc}
\hline Model & $\mathrm{r}$ & $\mathrm{R}^{2}$ & $\mathrm{SEE}$ & $\mathrm{P}$ \\
\hline \%Mort.=4.03+0.39(mean overstory scorch height $(\mathrm{cm}))$ & 0.79 & 0.63 & 4.37 & $<0.001^{*}$ \\
\%Mort. $=9.75+0.01$ (sum of overstory scorch heights $(\mathrm{cm}))$ & 0.69 & 0.47 & 4.89 & $<0.001^{*}$ \\
\hline \%Mort.=10.96+0.39(mean sapling scorch height $(\mathrm{cm}))$ & 0.42 & 0.18 & 7.28 & $0.010^{*}$ \\
\%Mort. $=16.41+0.03$ (sum of sapling scorch heights $(\mathrm{cm}))$ & 0.44 & 0.19 & 5.87 & $0.008^{*}$ \\
\hline
\end{tabular}

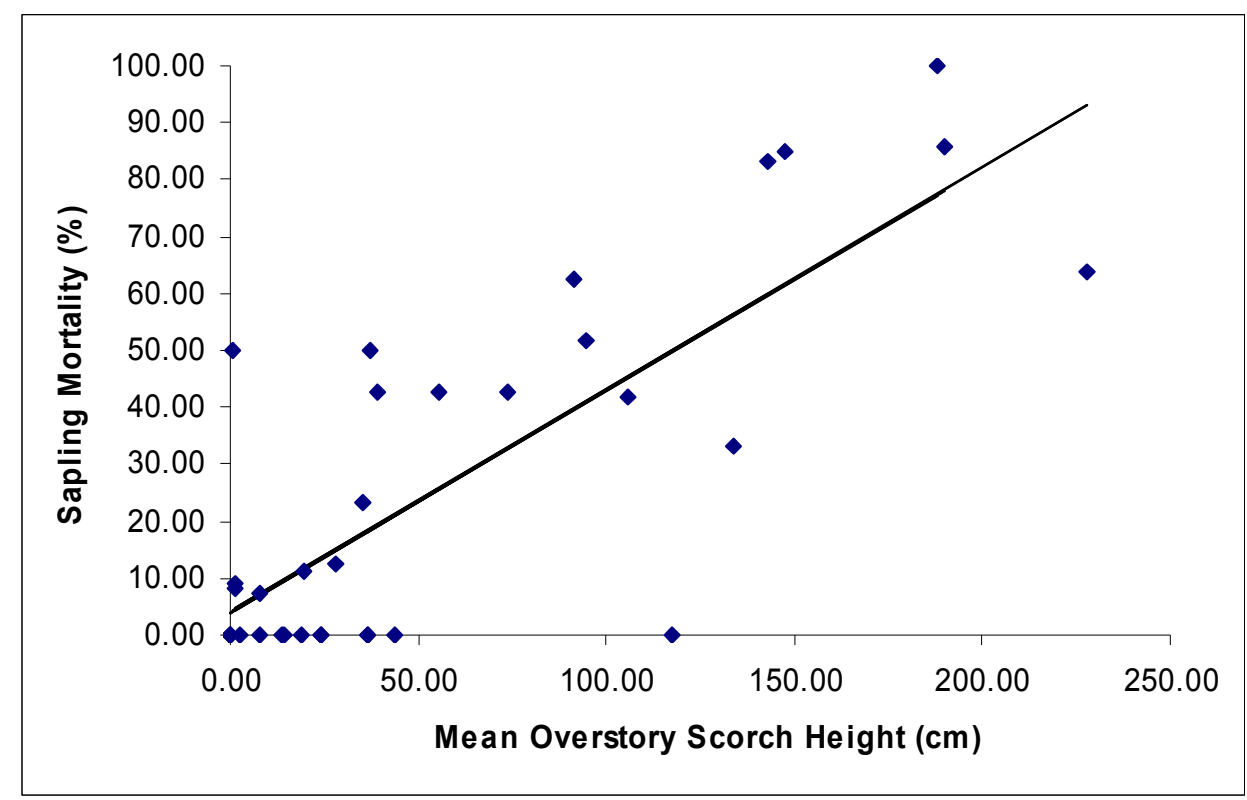

Figure 4.2. The relationship between mean overstory scorch height $(\mathrm{cm})$ and sapling mortality (\%).

When the sapling mortality analysis was restricted to mostly scorched plots, relationships/models were not nearly as sound. Therefore, these results were not reported. 


\section{Conclusions}

The results indicate that, at the plot level, the measured three-year post-fire overstory and sapling bole scorch height variables (mean and sum) are not significantly correlated to litter consumption or thermocouple temperature. The results do, however, indicate that sapling mortality (one growing season post-fire) is a function of the tested bole scorch height parameters, with the strongest independent variable being average overstory scorch height. This further illustrates the usefulness of scorch height as an estimator of relative fire intensity and fire effects, and will allow for an examination of how relative fire intensity relates to changes in exotic invasive plant populations (Chapter 5).

The relationship between average scorch height and sapling mortality also has the potential to be very useful for xeric mixed-oak and oak-pine fire managers. The mean overstory scorch height model indicates that $50 \%$ mortality can be expected at an average overstory scorch height of just over one meter. An average overstory scorch height just less than two meters would result in about $75 \%$ sapling mortality. An average overstory scorch height of about two and one-half meters would likely result in $95 \%$ mortality. This model can be used to make a quick and inexpensive assessment of fire-induced mortality in areas where pre- and post-fire saplings were not sampled. Managers could also use the information to adjust ignition patterns to alter the potential sapling mortality in similar xeric mixed-oak and oak-pine prescribed fires.

However, the model does have its limitations. It has not been tested against independent data, and should therefore be considered preliminary. However, I do feel that the model 
will provide a sensible estimate of plot-level sapling mortality (one year post-fire). Use of the model should be limited to xeric mixed-oak and oak-pine forests of the Ridge and Valley physiographic province. Also, due to the statistical outlier and its removal, model predictions should not be applied when pitch pine makes up a high percentage (>50\%) of the basal area in the area being burned.

Further analysis of existing information about both dependent and independent variables would help to better understand the relationships examined. For example, measures of scorch height models of mortality may be different for disparate species such as red maple (Acer rubrum L.) and chestnut oak. Also, because topography is related to scorch height (Loomis 1973), the effect slope percent, aspect, elevation, slope position, landform shape, etc. should be examined. Loucks and others (2004) found higher scorch heights in more xeric locations. Logistic or multiple regression models may provide improved predictions by incorporating these and other influential variables. 


\section{Literature Cited}

Braun, E.L. 1950. Deciduous forests of eastern North America. New York, NY: Macmillan. 596p.

Brown, A.A.; Davis, K.P. 1973. Forest fire control and use. $2^{\text {nd }}$ ed. New York, NY: McGraw-Hill.

Brown, J.K.; Reinhardt, E.D.; Fischer, W.C. 1991. Predicting duff and woody fuel consumption in northern Idaho prescribed fires. Forest Science. 37(6): 1550-1566.

Cain, M.D. 1984. Height of stem-bark char underestimates flame length in prescribed burns. USDA Forest Service Fire Management Notes. 45: 17-21.

Clinton, B.D.; Vose, J.M.; Swank, W.T. [and others]. 1998. Fuel consumption and fire characteristics during understory burning in a mixed white pine-hardwood stand in the southern Appalachians. USDA Forest Service Gen. Tech. Rep. SRS-12.

Core, E.L. 1966. Vegetation of West Virginia. Parsons, WV: McClain Printing Company. $1077 \mathrm{p}$.

Elliot, K.J.; Vose, J.M.; Clinton, B.D. 2002. Growth of eastern white pine (Pinus strobus $\mathrm{L}$.) related to forest floor consumption by prescribed fire in the southern Appalachians. Southern Journal of Applied Forestry. 26(1): 18-25.

Estepp, R. 1992. Soil Survey of Pendleton County, West Virginia. U.S. Soil Conservation Service.

Franklin, S.B.; Robertson, P.A.; Fralish, J.S. 1997. Small-scale fire temperature patterns in upland Quercus communities. Journal of Applied Ecology. 34: 613-630.

Iverson, L.R.; Yaussy, D.A.; Rebbeck, J. [and others]. 2004. A comparison of thermocouples and temperature paints to monitor spatial and temporal characteristics of landscape-scale prescribed fires. International Journal of Wildland Fire. 13: 311-322.

Loomis, R.M. 1973. Estimating fire-caused mortality and injury in oak-hickory forests. Research Paper NC-94. St. Paul, MN: USDA Forest Service, North Central Forest Experiment Station.

Loucks, E.M.; Arthur, M.A.; Loftis, D.L. 2004. Species and site differences in stembark char after prescribed fire in a southern Appalachian Hardwood Forest, Kentucky. In: Yaussy, D.A; Hix, D.M.; Long, R.P.; Goebel, C.P., eds. Proceedings, $14^{\text {th }}$ Central Hardwood Forest Conference; 2004 March 16-19; Wooster OH. Gen. Tech. Rep. NE316. Newton Square, PA: USDA Forest Service, Northeastern Research Station: 525p.

Marsh, M.A. 2005. Floristic dynamics of Appalachian pine-oak forests 
over a prescribed fire chronosequence. Morgantown, WV: West Virginia University. 275p. M.S. Thesis.

Regelbrugge, J.C.; Smith, D.W. 1994. Postfire tree mortality in relation to wildfire severity in mixed oak forests in the Blue Ridge of Virginia. Northern Journal of Applied Forestry. 11(3): 90-97.

Regulbrugge, J.C.; Conrad, S.G. 1993. Modeling tree mortality following wildfire in Pinus ponderosa forests in the central Sierra Nevada of California. International Journal of Wildland Fire. 3(3): 139-148.

SAS Institute Inc. 1993. SAS/ETS user's guide. Version 8.2. $2^{\mathrm{d}}$ ed. Cary, NC: SAS Institute Inc. $956 \mathrm{p}$.

USDA Forest Service. 1993. George Washington National Forest final revised land and resource management plan. U.S.D.A. Forest Service, George Washington National Forest, Roanoke, V.A.

Vose, J.M.; Swank, W.T.; Clinton, B.D. [and others]. 1999. Using stand replacement fires to restore southern Appalachian pine-hardwood ecosystems: effects on mass, carbon, and nutrient pools. Forest Ecology and Management. 114: 215-226.

Wyant, J.G.; Omi, P.N.; Laven, R.D. 1986. Fire induced tree mortality in a Colorado ponderosa pine/Douglas-fir stand. Forest Science. 32: 49-59. 


\section{CHAPTER 5}

Prescribed Fire and Invasion by Exotics in the Understory of a Xeric Appalachian Mixed-oak and Oak-pine Dominated Forest 


\section{Abstract}

The number and extent of prescribed fires in xeric mixed-oak and oak-pine ecosystems of the Appalachians has been steadily increasing. In general, these fires are set to promote restoration of historical forest structure and enhance tree regeneration of desirable species. These fires may, however, promote invasion by non-native invasive plants. Unfortunately, the relationship between fire and invasion by exotic plants in these forests is not well understood. This chapter focuses on the effects of a prescribed fire on understory exotic invasive plants in a xeric Appalachian mixed-oak and oak-pine dominated area of the Ridge and Valley. Several analytical methods were employed to determine if: (1) abundance and importance increased following the fire, (2) relative fire intensity played a role, and (3) environmental variables were related to populations. Indicator Species Analysis (ISA) and Nonmetric Multidimensional Scaling (NMS) ordination suggested that the prescribed fire had little effect on the abundance of understory exotic invasive plants. An Analysis of Variance (ANOVA) test $(\mathrm{n}=36)$ indicated that tree-of-heaven (Ailanthus altissima (P. Mill.) Swingle) showed significantly higher abundance and importance immediately following the prescribed fire, but was back to pre-fire levels after three full growing seasons. NMS ordination also implied that moister areas, where understory species richness is higher and where relative fire intensity is lower, provides a favorable microsite for the exotic invasive species. Abundance was positively correlated to these areas. Multiple logistic regression models indicated that environmental factors play more of a role than relative fire intensity in determining the probability of presence of exotic invasives in the understory. More research is needed on this topic for it to be fully understood. 


\section{Introduction}

Historically, fire has played a key role in maintaining forest composition in pine-oak and mixed-oak forests in West Virginia and throughout the Appalachians (Abrams 1992, Brose and others 2001, Schuler and McClain 2003, Sutherland and others 1995). Before fire suppression became a policy in the eastern United States (US) between the late 1920s and 1950s, these forests were shaped by a combination of large scale disturbances (e.g. drought, stand-replacing wildfire, hurricane, and insect or disease outbreak) and lowintensity fires. Sutherland and others (1995) estimated that major fires occurred about every 10 to 15 years in table mountain pine (Pinus pungens Lamb.) stands in southwestern Virginia. Both Brose and Waldrop (2006b) and Yarnell (1998) estimated that prior to the fire suppression era, stand level disturbances in the southern Appalachians occurred once every 6 to 13 years. Rentch and Hicks (2003) found that large canopy disturbances involving multiple trees occurred every 17 years in oak (Quercus spp.) dominated old-growth stands in the Central Hardwoods Region.

These types of disturbances formed stands of mixed-oak and pine, and more frequent low-intensity fires maintained this composition (Abrams 1992, Brose and others 2001). Several studies have estimated low intensity fire return intervals in these forests. These return intervals are comparable to those of stand-level disturbances. Sutherland and others (1995) estimated that low intensity fires occurred every 9 to 11 years. Harmon (1982) found that periodic fires occurred, on average, about every 12 years in the Great Smoky Mountains. Shumway and others (2001) calculated fire-return intervals of 8 years in an oak forest in western Maryland. Schuler and McClain (2003) reported fire-return 
intervals of 7 to 15 years in an oak forest in the Ridge and Valley Physiographic Province of eastern West Virginia. Weibull median fire return intervals of four to eight years occurred in rimrock oak-pine communities at the New River Gorge National River in West Virginia (Maxwell 2006).

The diminution of fire as a disturbance agent, and the associated change in structure and species composition, has led to a decline of both oak and, especially, pine communities in some areas (Abrams 1992, Brose and Waldrop 2006a). Continued absence of fire in oakpine communities could soon lead to a decline in pine species, and eventual oak dominance (Abrams 1992; Sutherland and others 1995). Table mountain and pitch pine (Pinus rigida P. Mill.) dominated communities, in particular, are recognized by the Southern Appalachian Man and the Biosphere (SAMAB), a program that encourages the utilization of ecosystem and adaptive management principles, as one of 31 rare communities (SAMAB 1996). Researchers once thought that, without stand initiating fires, successful regeneration of table mountain and pitch pine communities could not occur (Sutherland and others 1995, Williams and Johnson 1990). Recent research, however, suggests that repeated low intensity fires can achieve successful table mountain pine regeneration (Waldrop and others 2006). Successful management of mixed-oak and oak-pine forests, without restoration of historical fire regimes, is difficult (Abrams 1992, Barden \& Woods 1976, Marsh 2005, Sutherland and others 1995, Welch and others 2000, Williams \& Johnson 1990). This information has spurred land managers to increase the number and extent of prescribed fires in these forest ecosystems in efforts to restore them to their historical structure and to promote regeneration of native oak and 
pine species. This increase in prescribed fire is carried out primarily on federal lands (Elliot and others 1999, Lafon and others 2005).

In addition to the management challenges resulting from altered disturbance and fire regimes, the futures of these ecologically important forests are likely to be negatively affected by exotic invasive plants (Mlot 2003, Williams 1998). Highly invasive exotic plant species such as tree-of-heaven (Ailanthus altissima (P. Mill) Swingle), garlic mustard (Alliaria petiolata (Bieb.) Cavara \& Grande), and Japanese stilt grass (Microstegium vimineum (Trin.) A. Camus may drastically inhibit successful establishment and development of native plants and lead to a decrease in regional biodiversity (D’Antonio and Vitousek 1992) and altered ecosystem processes (Vitousek and Walker 1989). Furthermore, if exotic invasive plants become well established, they may alter forest fuel properties and impact fire behavior and fire regime characteristics (e.g. frequency, intensity, extent, type, and seasonality) (Brooks and others 2004, D’Antionio and Vitousek 1992, Mack and D'Antonio 1998). If these fire regime changes promote the dominance of the invaders, then an invasive plant-fire regime cycle can be established, making ecological restoration much more difficult (Brooks and others 2004). Given that the cumulative numbers of exotic invasive plant species in the forests of West Virginia may be increasing over time (Huebner 2003), few ecologists and conservation biologists will argue that worst of the problems caused by these unwanted plant pests are behind us. 
In addition to encouraging historical forest structure and enhancing tree regeneration, natural and prescribed fire has been shown to indirectly promote increases in both richness and cover of native herbaceous plants in forest understory communities (Bowles and others 2007, Hutchinson 2006, Nuzzo and others 1996). These increases allow for greater diversity and, in general, a better habitat for local fauna. However, fire and other disturbances (i.e. thinning/harvesting and herbicide treatments) that decrease canopy cover and increase understory light, also may promote invasion by exotic plant species (Bossard 1991, D'Antonio 1993, Hobbs and Huenneke 1992, Hutchinson and others 2004, Larson 2003, Mooney and Hobbs 2000, Pyle 1995, Stapanian and others 1998).

The relationship between fire and invasion by exotic plants is not well understood. A few studies have directly examined this relationship in different forested ecosystems. The results, however, are variable and in some cases, contradictory. Some have found that fire, natural or anthropogenic, promoted the establishment and abundance of exotic invasive plants. Others have found little to no change or negative responses by exotic invasives. For instance, Bridgewater and Backshall (1991) found that natural fire enhanced exotic invasive forbs and grasses in Eucalyptus woodlands of Western Australia. Hester and Hobbs's (1992) results contradicted those of Bridgewater and Backshall (1991). They reported decreases in the density of exotic invasive forbs and grasses in Eucalyptus woodlands of the same region. Wein and others (1992) found that exotic annuals and biennials invaded recently burned areas of Wood Buffalo National Park in Canada. In ponderosa pine (Pinus ponderosa P. \& C. Lawson) forests of the western US, fire has been shown to increase both the richness and abundance of exotic 
invasive species (Crawford and others 2001, Griffis and others 2001). Both of these studies showed that exotic invasive species were far more abundant where fire severity, or intensity, was highest. Laughlin and others (2004), on the other hand found little to no change in exotic invasive plant populations following wildfire in ponderosa pine forests located in Grand Canyon National Park in Arizona. In other areas of the western US, like the California coast, interior valleys, and other western grassland and prairie ecosystems, fire is used as a management to control exotic invasives and promote native vegetation (Rice 2005).

Studies in the eastern US showed similar variability in the effects of fire on exotic invasive plants. Bowles and others (2007) showed that seventeen years of repeated annual low intensity burning promoted garlic mustard abundance in an Illinois oak forest. In their study, garlic mustard persisted and showed greater abundance in burned areas relative to unburned areas. Contrary to Bowles and other's (2007) findings, Nuzzo and others (1996) found that repeated annual burnings facilitated a reduced abundance of garlic mustard in a sand forest in Illinois. Nuzzo (1991) reported that garlic mustard showed no decline with low intensity fire and some decline with mid-intensity fire. Glasgow and Matlack (2006) found that prescribed burning and canopy-opening management practices facilitated invasion by Japanese stilt grass and multiflora rose (Rosa multiflora Thunb. ex Murr.) in a mixed deciduous forest of Ohio. Doren and Whiteaker (1990) reported little to no change in the populations of the exotic invasive Brazilian pepper tree (Schinus terebinthifolius Raddi) in Florida woodlands following fire. Based on the available literature, the variable population responses of exotic 
invasive plants to fire appear to be due to both regional and local landscape variation (biology, different climates and microsites, etc.), and to be both site and species specific. That is, it is highly likely that responses to fire will be different in dissimilar areas or between disparate species on the same site.

Direct assessments of the relationship between fire and exotic invasive plant populations in forested ecosystems are limited to the abovementioned studies. Furthermore, no documented studies have explored this relationship in West Virginia. Perhaps more importantly, it has not been examined in forests of the Ridge and Valley Physiographic Province, an area that because of its unique species composition and climate is especially suited for the reintroduction of fire to achieve management goals (Thomas-Van Gundy and others 2007, Lafon and Grissino-Mayer In Press). The use of prescribed fire in oak and oak-pine forests in this region is steadily increasing, especially on the George Washington National Forest (GWNF), and has become a critically important management issue to the general public, as well as to foresters, biologists, ecologists, and other land and prescribed fire managers. GWNF lands experienced a 2,240 \% increase in area prescribed burned from the 1980s to the $1990 \mathrm{~s}$, and a $140 \%$ increase from the $1990 \mathrm{~s}$ to the 2000 s.

The hot, dry hillsides in this area provide ecologically unique ecosystems whose futures are at risk, not only due to altered fire regimes, but also due to invasion by exotic plants. Little is known about the relationship between prescribed fire and invasions by exotic invasive plants in these areas, hence, as the use of fire as a management tool increases, 
exotic invasives could be a major threat to future forest composition. Increases in establishment and abundance of exotic invasives may have considerable negative impacts on native plant communities. If this is the case, many areas scheduled to be burned in the future may require exotic invasive monitoring or management prior to the application of prescribed fire.

This study focuses on the effects of a prescribed fire on exotic invasive plants in a xeric Appalachian mixed-oak and oak-pine dominated forest of the Ridge and Valley. The analysis focuses on the understory stratum where all early establishing species, including exotic invasives, will be found (Huebner 2007). Three research questions were investigated: (1) how does prescribed fire affect the abundance and importance of exotic invasive plants?, (2) does relative fire intensity play a role in abundance changes?, and (3) are there exotic invasive plant-environmental relationships? The intent of this study was to help foresters and prescribed fire managers to better understand the interaction of prescribed fire and exotic invasive plant species over time and across the landscape in xeric mixed-oak and oak-pine forest communities.

\section{Methods}

\section{Study Site}

This study was conducted at Dunkle Knob located on the North River Ranger District (formerly the Dry River Ranger District) of the GWNF, Pendleton County, West Virginia $\left(38^{\circ} 37^{\prime} \mathrm{N}, 79^{\circ} 14^{\prime} \mathrm{W}\right)$. The study area encompassed 313.6 ha and is composed of xeric mixed-oak and oak-pine communities. The area is within the Ridge and Valley 
Physiographic Province and is uniquely situated in the rain-shadow of the Allegheny Mountains, which causes a climate that is much drier than the rest of the state (Core 1966). The area is characterized by an average annual precipitation of $82 \mathrm{~cm}$, an average annual temperature of $10.9^{\circ} \mathrm{C}$, and a growing season of approximately 144 days (Estepp 1992). Forests of the region can be characterized as being part of the former oak-chestnut cover type (Braun 1950).

The topography is highly dissected with slopes ranging from 6 to $70 \%$. Elevation ranges from 573 to $848 \mathrm{~m}$. The predominant soil type is of the Berks-Weikert association. They are loamy-skeletal, mixed, Dystrochrepts formed from acidic shale, siltstone, or sandstone bedrock. The soils are droughty, infertile, and often contain numerous rock outcroppings (Estepp 1992).

The Dunkle Knob area was purchased by the USDA Forest Service in 1923. After its purchase, no fires were documented in the Dunkle Knob area until a prescribed fire was ignited by GWNF personnel on March 29 of 2004 (Marsh 2005). At the time of the fire, air temperatures ranged from $11^{\circ}-21^{\circ} \mathrm{C}$ and relative humidity ranged from 29 to $76 \%$. Winds were primarily from the northwest and southeast at a speed of $2-10 \mathrm{Km} / \mathrm{H}$. The interior of the mountain was ignited in a northeast-southwest pattern from top to bottom by a helicopter dropping delayed aerial ignition devices. The prescribed fire perimeter was established using existing roads and limited new fire line construction as fire breaks. This perimeter area was ignited by ground personnel using drip torches (Marsh 2005). Based on data from five thermocouple probes, the fire burned at an average temperature 
of $148.3^{\circ} \mathrm{C}$ with an average rate of spread of $2.3 \mathrm{~m} / \mathrm{min}$. Timber harvesting occurred on, and around the base of, the mountain in the 1950s and 1960s, as well as in the early 1970s and 1980s (Figure 5.1). The harvests are described in detail in Chapter 3. Eastern white pine (Pinus strobus L.) was planted in some cases after harvesting.

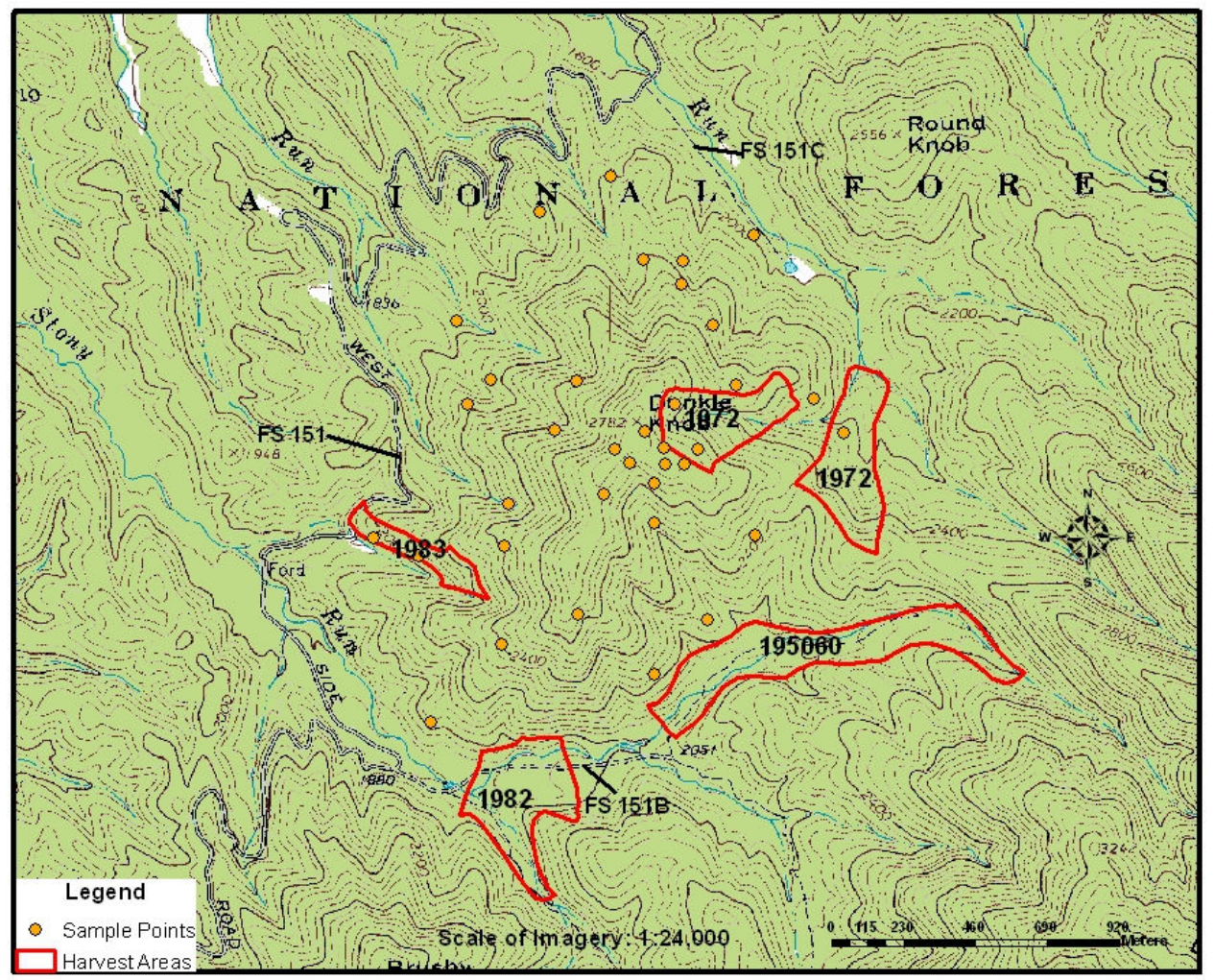

Figure 5.1. Harvest areas on, and around the base of, Dunkle Knob.

Pre-fire (2003) total basal area for the overstory (trees $\geq 12.7 \mathrm{~cm}$ diameter at breast height (DBH)) averaged $20.8 \mathrm{~m}^{2} / \mathrm{ha}$, and increased to $23.0 \mathrm{~m}^{2} / \mathrm{ha}$ by 2007 (three full growing seasons after the fire). In 2007 the most abundant overstory species included chestnut oak (Quercus prinus L.), Virginia pine (Pinus virginiana P. Mill.), and table mountain pine (see Chapter 3). 


\section{Field Methods}

Thirty-six circular 0.05 ha overstory plots were randomly established at the Dunkle Knob study site during the summer of 2003 (pre-fire). Eighteen plots were randomly established on northeast- $\left(315-235^{\circ}\right)$ and southwest- $\left(236-314^{\circ}\right)$ facing slopes. Within each aspect class, nine plots each were established above and below $748 \mathrm{~m}$ elevation (see Marsh (2005) for complete sampling experimental design). To aid in future relocation, sample points were located with a Global Positioning System (GPS) and a piece of steel rebar was driven into the ground at plot center. Also, plot boundaries were flagged.

Each plot was inventoried in the summers of 2003 (pre-fire), 2004 (three to four months post-fire) and 2007. All overstory trees, both living and dead, were tallied. Each tree was identified to species (although a small number of dead trees could not be positively identified), and crown class was recorded. Stem diameter was measured to the nearest $0.1 \mathrm{~cm}$ using a diameter tape. During the 2007 inventory, bole scorch height, defined as height of the highest point of bole blackening on the uphill face of the tree (Regelbrugge and Smith 1994), was measured to the nearest $15 \mathrm{~cm}$ using a height pole. The sapling layer (all trees $2.54 \mathrm{~cm} \leq \mathrm{DBH} \leq 12.6 \mathrm{~cm}$ ) was sampled using a circular 0.01 ha plot located at the center of each overstory plot $(n=36)($ Figure 5.2). All saplings were identified to species and DBH. Bole scorch height on saplings was also recorded as described above.

Bole scorch height is also described as stem-bark char or height of bole blackening. This variable has been proven to be a significant predictor of post-fire mortality in various 
forest types (Loomis 1973, Regelbrugge and Conrad 1993, Regelbrugge and Smith 1994, Wyant and others 1986). It has also been proven to be highly correlated with areal percent canopy scorch and top-kill of individual trees (Regelbrugge and Smith 1994). Although bole scorch height underestimates flame length in prescribed burns (Cain 1984), these findings indicate that it can be used to estimate relative fire intensity at the stand-level. Chapter 4 illustrates the usefulness of scorch height as an estimator of relative fire intensity and fire effects at the plot level on the Dunkle Knob site.

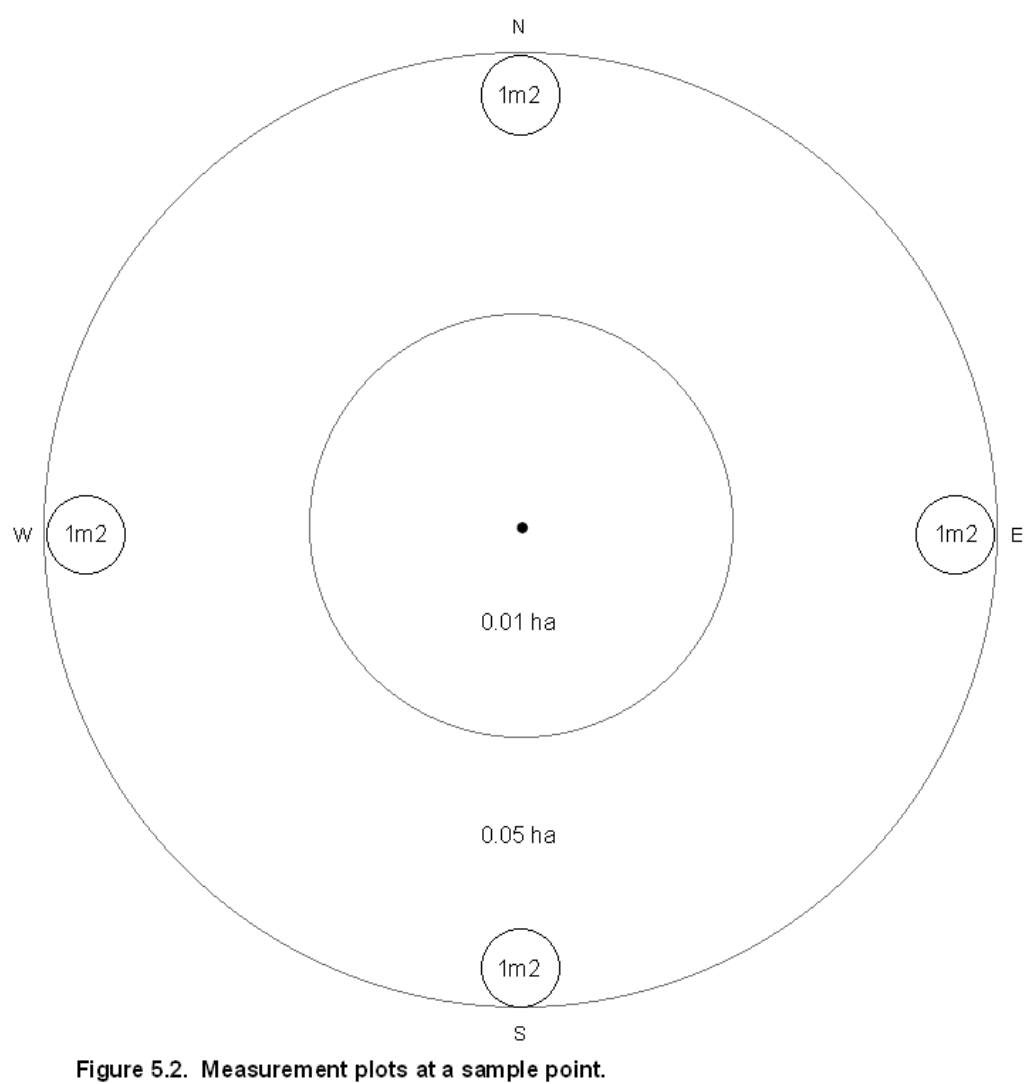


Within each 0.05 ha plot, $1 \mathrm{~m}^{2}$ circular plots were established at $12.06 \mathrm{~m}$ from the plot center in each of the four cardinal directions for understory vegetation measurements (Figure 5.2). In 2003, 2004, and 2007 (three full growing seasons after the fire), a $50 \mathrm{~cm}^{2}$ Mylar® circle representing $0.5 \%$ was used to estimate cover (to the $0.5 \%$ level) of each herb, shrub, vine, and tree seedling $\leq 1 \mathrm{~m}$ in height rooted in these plots. There was a $<1 \%$-cover category, which was given a value of $0.5 \%$ for data analysis purposes. Estimates of percent ground cover of moss/lichen, rock, bare ground, dead wood, living wood, and litter were also recorded.

A vegetation census using the timed-meander technique was performed on each of the 0.05 ha plots $(n=36)$ in 2007 . This method has been proven effective for documenting species richness, defining flora, and for detecting both exotic invasive (Huebner 2007) and threatened and endangered species (Goff and others 1982). Each plot was thoroughly walked, starting and ending at North from plot center, and time was noted every ten minutes as new species were tallied. All species having a height of $\leq 1 \mathrm{~m}$ were tallied. Unknown plants were collected and pressed for later identification by botanical expert Dr. Cynthia Huebner, Botanist, United States Department of Agriculture (USDA) Forest Service, Northeastern Research Station. The largest portion of the samples were identified by Dr. Huebner, however, in a few cases, herbaceous plant expert William Grafton, Wildlife Extension Specialist, West Virginia University (WVU) Division of Forestry and Natural Resources, participated in identification. 
Spherical crown densiometer readings were taken to estimate percent canopy cover on Dunkle Knob in 2003, 2004, and 2007. Five densiometer measurements were taken at each sample point; one at the center of the overstory and sapling plots and one at each of the four $1 \mathrm{~m}^{2}$ sub-plots. The measurement at the center of the overstory plot was taken facing downhill, while the remaining were made facing plot center.

\section{Analytical Methods}

Exotic invasive species were defined using published state and regional flora (Core 1966, Gleason and Cronquist 1991, Harmon and others 2006) and available species lists (The Bugwood Network 2006, USDA Forest Service, Eastern Region 1998). Definitions were crosschecked by Dr. Cynthia Huebner to ensure correctness. Nomenclature follows Harmon and others (2006) and the Integrated Taxonomic Information System (ITIS) (2001). For some of the pressed samples, the distinguishing characteristics between certain species were not present (e.g., reproductive structures) or the plant was too underdeveloped for accurate identification. In these instances, taxonomic classification to only the family or genus level was possible. In some cases, positive identification of a particular specimen could not be made. These specimens were classified to the closest taxonomic level that could be achieved with confidence, and cf. was added to the nomenclature.

\section{$\underline{\text { Pre-treatment vs. Post-treatment }}$}

Pre-treatment (2003) and post-treatment (2007) understory species composition was evaluated with Multi-response Permutation Procedures (MRPP) using PC-ORD 5 
software (McCune and Mefford 1999). Although MRPP, and other multivariate analysis methods, avoid distributional assumptions, one should adjust the data matrix if it is extremely variable. McCune and others (2002) suggest that row and column variability, measured by the Coefficient of Variation (CV), between 50 and $100 \%$ will have a moderate effect on the outcome of multivariate analyses.

Input data were pre-fire and post-fire species plot percent cover values (average of $1 \mathrm{~m}^{2}$ $(n=144)$ for each 0.05 ha plot $(n=36) .2004$ data were limited, and therefore were not included in the analysis. Initial data screening indicated a high CV of column (species) totals (448\%). Therefore data were adjusted to reduce this variability. First, rare species (those occurring in less than five percent of the sample units) were deleted. This reduced the $\mathrm{CV}$ of column totals to $297 \%$. Data were then subjected to arcsine square root transformation, further reducing the $\mathrm{CV}$ of column totals to $161 \%$. Because the goal of $<$ $100 \% \mathrm{CV}$ had not been met, a general relativization was used. The data were also examined for species (columns) that fell more than two standard deviations above or below the mean. Using this method, no potential outliers were identified. The final matrix (data set of plot $\mathrm{x}$ species) exhibited row and column totals with CVs of 56 and 0 $\%$, respectively.

MRPP is a nonparametric procedure for testing the hypothesis of no difference between two or more groups of entities (McCune and others 2002). This method has been proven useful in various types of ecological studies (Hartman and McCarthy 2007, Rentch and others 2005, Zimmerman and others 1985). The procedure yields three statistics: a 
weighted within-group average distance or $\delta$ (using Sorensen, or city-block, distance), the $\mathrm{T}$ statistic, and the A statistic. The $\mathrm{T}$ statistic describes the separation between groups and is calculated using the formula:

$$
T=\frac{O B S E R V E D \delta-E X P E C T E D \delta}{S . D E V . O F E X P E C T E D \delta},
$$

where $\delta=$ the weighted within-group distance (McCune and others 2002). The T statistic describes the separation between groups; stronger separations between groups are represented by more negative T values. PC-ORD 5 (McCune and Mefford 1999) provides a probability value for the likelihood of observing the difference, $\mathrm{T}$, by chance. The A statistic is an estimate of within-group homogeneity, compared with random expectation and is calculated using the formula:

$$
A=1-\frac{\text { OBSERVED } \delta}{\operatorname{EXPECTED} \delta},
$$

again where $\delta=$ the weighted within-group distance (McCune and others 2002). This statistic provides a description of the "effect size" that is independent of the sample size with values ranging from 0 (heterogeneity within groups equals expectation by chance) to 1 (sample units are identical within groups) (McCune and others 2002).

Indicator Species Analysis (ISA) (Dufrene and Legendre 1997) was used in conjunction with MRPP to determine if any understory species, particularly exotic invasives, showed 
a greater than expected fidelity to pre-fire or post-fire conditions based on abundance and occurrence. Again, PC-ORD 5 software (McCune and Mefford 1999) was used for the analysis. PC-ORD 5 first calculates an indicator value for each species. The indicator values $\left(\mathrm{IV}_{\mathrm{kj}}\right)$ can range from 0 (no indication) to 100 (perfect indication) and are calculated using the equation:

$$
I V_{k j}=100\left(R A_{k j} \times R F_{k j}\right),
$$

where $\mathrm{j}$ is each species in each group $\mathrm{k}$, and $\mathrm{RA}=$ relative abundance and $\mathrm{RF}=$ relative frequency (McCune and others 2002). The statistical significance of the highest $\mathrm{IV}_{\mathrm{kj}}$ for each species is then tested using a Monte Carlo method that randomly assigns each sample plot to groups 1000 times. The null hypothesis $\left(\mathrm{H}_{\mathrm{o}}\right)$ is that the maximum $\mathrm{IV}_{\mathrm{kj}}$ for each species is no larger than would be expected by chance (i.e., the species has no indicator value) (McCune and others 2002). The significance level for hypothesis tests was set at $\alpha=0.05$.

In addition, Analysis of Variance (ANOVA) was used to compare exotic invasive species percent cover and Importance Value (IV) means for each sample period (pre-fire, three to four months post-fire, and three full growing seasons post-fire). IVs were calculated from the $1 \mathrm{~m}^{2}$ data (averaged for each 0.05 ha plot) using the formula:

$$
I V=\frac{R E L A T I V E \text { PERCENT COVER }+ \text { RELATIVE FREQUENCY }}{2}
$$


The AVOVA tests were performed using SAS 9.1 software (SAS Institute, 2003) using a General Linear Model (GLM) procedure. The significance level for these tests was set at $\alpha=0.05$. If the ANOVA tests showed significant differences in means, the means were evaluated using Fisher's protected Least Significant Difference (LSD) test (t-test).

The Nonmetric Multidimensional Scaling (NMS) ordination technique was also used to compare pre-fire and post-fire understory species composition. Input data for the NMS ordination were the same as the MRPP input data (percent cover or abundance) and is described above. NMS is a non-parametric iterative ordination technique that uses ranked distances to arrange sample plots along a number of axes determined by a minimal stress configuration, and is considered by McCune and others (2002) as the most generally effective ordination method for ecological community data. The method has been proven useful in various types of forestry studies (De Grandpré and others 2005, Hutchinson and others 2005, Schuler 2004, Small and McCarthy 2002).

The NMS ordination was performed using PC-ORD 5 software (McCune and Mefford 1999) with the Sorensen, or city-block, distance measure. The following settings were used to determine appropriate dimensionality and to avoid local minima: a six dimensional solution ( $\mathrm{six}$ axes), 50 runs of real data and 50 runs of randomized data (maximum of 500 iterations for each run) for a Monte Carlo test of significance, an initial step length of .20, an instability criterion of 0.0005 , and random starting coordinates. 
Following a finding that the results were not due to chance $(\mathrm{P}=0.020)$, a three dimensional solution provided the lowest stress and was selected as the final solution for the NMS ordination. After finding the optimal number of axes for the solution, the best ending point in the preliminary analysis was used as the starting point in the final run. Ordination axes were rotated to align the horizontal axis with the strongest explanatory (relative fire intensity and environmental) variables. The explanatory variables were then correlated with the ordination axes. Understory species were also correlated to the ordination axes. Relative fire intensity variables used in the correlation included average overstory scorch height and sapling mortality. Environmental variables were: percent slope, Topographic Relative Moisture Index (TRMI) (Parker 1982), understory species richness, percent change in canopy cover (2003 to 2007), percent canopy cover (2007), elevation (m), distance (m) from areas where tree-of-heaven has ascended into the main canopy (see Chapter 3), distance (m) from harvesting, distance from roads (m), and percent ground cover of moss, rock, bare ground, living wood, dead wood, and litter. Initial data screening indicated that percent ground cover of rock, bare ground, and both living and dead wood had a skewness of greater than one; therefore, as recommended by McCune and others (2002), a Log 10 transformation was applied to these variables.

\section{Exotic Invasive Plant Species and Relative Fire Intensity/Environmental Variables}

The NMS ordination technique was also used to examine post-fire data for relationships between understory exotic invasive plant species and both relative fire intensity and environmental variables. This NMS ordination was performed using the post-fire (2007) timed meander data (presence/absence) for each 0.05 ha plot $(\mathrm{n}=36)$. Initial data 
screening indicated a high CV of column (species) totals (116\%). Therefore data were adjusted to reduce this variability. First, rare species (those occurring in less than five percent of the sample units) were deleted. This reduced the CV of column totals to $83 \%$. $\mathrm{CV}$ of rows was found to equal $22 \%$. Beals smoothing (Beals 1984) was then applied to the data. Beals smoothing is an extremely powerful transformation that replaces presence/absence data with quantitative values that represent the "favorability" of each sample for each species, regardless of whether the species was present in the sample (McCune and others 2002). The data were also examined for species (columns) that fell more than two standard deviations above or below the mean. Using this method, no potential outliers were identified. The final "smoothed" matrix (data set of plot $\mathrm{x}$ species) exhibited row and column totals with CVs of 4 and $82 \%$, respectively.

The NMS ordination methods, and explanatory variables, were the same as those used for the NMS ordination used to examine pre-fire versus post-fire data and are described in the previous section. Following a finding that the results were not due to chance $(\mathrm{P}=$ 0.020), a two dimensional solution provided the lowest stress and was selected as the final solution for the NMS ordination of "smoothed" timed meander data.

In addition to the NMS ordinations, relationships between understory exotic invasive plants and relative fire intensity and environmental variables were examined by developing multiple logistic regression models to predict the post-fire (2007) probability of presence of tree-of-heaven and garlic mustard in the understory. Each of these species was found on seven of the 0.05 ha plots. Logistic regression models differ from 
regression models in that they are not linear and explanatory variables can be either quantitative or qualitative. These models have become the standard method of analysis for describing the relationship between a discrete, or dichotomous, response variable and one or more explanatory variables across several different disciplines (Hosmer and Lemeshow 2000). A third multiple logistic regression model was developed to predict the post-fire (2007) likelihood of the presence of all species listed by the USDA Forest Service as highly invasive in the eastern region of the US. These plants are known as "Category 1" invasives and are all non-native, highly invasive plants which invade natural habitats and may have the ability to replace native species (USDA Forest Service, Eastern Region 1998). For this study, Category 1 exotic invasives included: tree-ofheaven, garlic mustard, Japanese stilt grass, and autumn olive (Elaeagnus umbellata Thunb.). As a group these species were found on twelve of the 0.05 ha plots. A fourth multiple logistic regression model was developed to predict the probability of presence of tree-of-heaven immediately post-fire (2004). During this time tree-of-heaven was found on eleven of the 0.05 ha plots. All 2007 post-fire response variable data came from the timed meander inventory. In all models the explanatory, or predictor, variables were the same as those used in the NMS ordinations.

For exploratory data analysis purposes, each independent variable was first evaluated individually using the method of Maximum Likelihood Estimates (MLE) to estimate the coefficients of the logistic regression function. The MLEs were calculated using SAS 9.1 software (SAS Institute, 2003) using a Logistic procedure. Significance was determined at $\alpha=0.05$ using the Wald statistic. Those independent variables with a statistically 
significant MLE were then evaluated together using multiple logistic regression with backward selection $(\mathrm{P}$ to enter and $\mathrm{P}$ to stay $=0.10)$. In these multiple logistic regression models, coefficients were derived from MLEs and expressed as odds ratios. In this study, odds ratios represent how a unit change in the value of an independent variable is associated with the probability of presence of a particular exotic invasive plant species in the understory stratum. The Wald statistic was again used to test the significance of explanatory variables in the full models. A Hosmer-Lemeshow test (Hosmer and Lemeshow 1980) was used to determine the goodness-of-fit between observed and predicted values for each multiple logistic regression model.

\section{Results}

A total of 152 vascular plants were identified in the understory from the $1 \mathrm{~m}^{2}$ plots $(\mathrm{n}=144)$ prior to the prescribed fire in 2003 (Appendix Table 1). Of these, only four, or approximately $3 \%$ were defined as exotic invasives. These included: tree-of-heaven, garlic mustard, Canada bluegrass (Poa compressa L.), and Bell's honeysuckle (Lonicera $\mathrm{X}$ bella Zabel). Forty-five percent of the identified plants were ferns and forbs, while 22, 16 , and $16 \%$ were graminoids, shrubs and vines, and trees, respectively. In 2007 (three full growing seasons post-fire), a total of 139 vascular plants were identified in the understory from the $1 \mathrm{~m}^{2}$ plots (Appendix Table 2). Only three, or approximately $2 \%$, of these were defined as exotic invasives: tree-of-heaven, garlic mustard, and Canada bluegrass. Again the majority of the identified plants were ferns and forbs (55\%). Graminoids, shrubs and vines, and trees made up 16,16, and $14 \%$ of the identified plants, respectively. Based on paired t-tests, mean species richness was, on average, 
significantly higher on the 360.05 ha plots prior to the fire (17.53 pre-fire compared to 16.06 post-fire $)(\mathrm{P}=0.022)$. Evenness and diversity averaged 0.66 and 1.85 pre-fire, compared to 0.67 and 1.81 post-fire, respectively. Neither of these measures were significantly different $(\mathrm{P}=0.361$ and 0.254$)$.

The post-fire timed meander inventory identified a total of 245 vascular plant species (Appendix Table 3). Of these, only six, or approximately $2 \%$ were defined as exotic invasives. Exotic invasives included: tree-of-heaven, garlic mustard, common sheep sorrel (Rumex acetosella L.), Japanese stilt grass, Canada bluegrass, and autumn olive. Percentages of habit types were similar to those calculated from the $20071 \mathrm{~m}^{2}$ data. Ferns and forbs, graminoids, shrubs and vines, and trees made up 58,12, 15, and $15 \%$ of the identified plants, respectively. Based on a paired t-test, the timed meander inventory yielded a significantly higher average species richness of 48.56 , compared to 16.06 calculated from the $1 \mathrm{~m}^{2}(\mathrm{P}<0.001)$. Evenness and diversity were not compared for the two sampling methods due to the fact that the timed meander only provided presence/absence data.

\section{Pre-treatment vs. Post-treatment}

\section{$\underline{\text { MRPP and ISA }}$}

The MRPP provided evidence that the pre-fire (2003) and post-fire (2007) understory layers can be characterized by somewhat different species composition. The T statistic, which represents the separation between pre-fire and post fire composition, was found to equal -10.81 and was highly significant $(\mathrm{P}<0.001)$. The A statistic, an estimate of 
within group homogeneity, was found to equal 0.021 , indicating low homogeneity between plots within groups. A Mantel randomization test (Mantel 1967), which tests the hypothesis of no difference between two matrices (in this case pre-fire plot x species and post-fire plot $\mathrm{x}$ species), also indicated that compositional differences exist between prefire and post-fire understory layers $(\mathrm{r}=0.46, \mathrm{P}=0.001)$.

The ISA suggested that some species were more likely to occur in the understory postfire than pre-fire and vice versa (Table 5.1). Although the exotic invasives garlic mustard and Canada bluegrass each exhibited a stronger $\mathrm{IV}_{\mathrm{kj}}$ in the post-fire understory, their observed $I V_{k j}$ did not exceed their expected $I V_{k j}$ and were, therefore, not significant indicators. Tree-of-heaven and Bell's honeysuckle were not considered in the analysis because they occurred in less than five percent of the sample plots. Fireweed (Erechtites hieraciifolia (L.) Raf. ex DC.), Unknown (UK) Poaceae, and grape (Vitis spp.) were most strongly associated with the pre-fire understory $(\mathrm{P}<0.002)$. Pignut hickory $($ Carya glabra (P. Mill) Sweet) and Carolina saxifrage (Saxifraga caroliniana Gray) showed the strongest associations with the post-fire understory $(\mathrm{P}<0.004)$.

\section{$\underline{\text { ANOVA }}$}

Both percent cover and IVs were quite low for all exotic invasive species during all measurement periods (Figures 5.3 and 5.4). None of the species yielded an average percent cover that was greater than $0.5 \%$. All IVs were lower than 1.0, except for garlic 
mustard pre-fire, and varied by species (Figure 5.4). Bell's honeysuckle was not considered in the analysis because it only occurred on one plot pre-fire and was absent during both post-fire measurement periods.

Table 5.1. Pre-fire and post-fire species Indicator Values (IVkj). Only species whose observed IVkj exceeds expected IVkj at P-values $<0.05$ are shown.

\begin{tabular}{lcccccc}
\hline & \multicolumn{2}{c}{ Observed } & & & & \\
Species & IVkj & Maximum Expected IVkj & SD & P \\
& Pre- & Post- & & & & \\
& fire & fire & & 34.8 & 4.54 & 0.042 \\
Acer rubrum & 0 & 44.3 & 13.4 & 3.66 & 0.009 \\
Carex cephalophora & 0 & 25.2 & 13.4 & 3.7 & 0.032 \\
Carex cf pensylvanica/lucorum & 22.3 & 0 & 28 & 4.69 & 0.002 \\
Carya glabra & 0 & 47.3 & 7.4 & 2.82 & 0.024 \\
Carya ovata & 16.7 & 0 & 10.1 & 3.21 & 0.031 \\
Dichanthelium commutatum & 0 & 17.5 & 13.5 & 3.77 & 0.001 \\
Erechtites hieraciifolia & 26.9 & 0 & 22.5 & 4.2 & 0.034 \\
Houstonia longifolia & 0 & 31.9 & 8.4 & 2.83 & 0.012 \\
Pinus spp. & 19.4 & 0 & 25.9 & 4.68 & 0.028 \\
Potentilla simplex & 0 & 37.1 & 30.2 & 4.71 & 0.047 \\
Quercus prinus & 0 & 39.6 & 10.1 & 3.22 & 0.003 \\
Saxifraga caroliniana & 0 & 25 & 13.4 & 3.6 & 0.001 \\
UK Poaceae & 36.1 & 0 & 45 & 3.69 & 0.017 \\
Vaccinium pallidum & 0 & 54.5 & 14.3 & 3.67 & 0.001 \\
Vitis spp. & 38.9 & 0 & & & \\
\hline
\end{tabular}

For all exotic invasive species, except tree-of-heaven, the null hypothesis $\left(\mathrm{H}_{\mathrm{o}}\right)$ of $\mu 1=\mu 2$ $=\mu 3$ was accepted $(\mathrm{P}>0.05)$ for both mean percent cover and IVs. Therefore, only treeof-heaven percent cover and IV means were evaluated using Fisher's Least Significant Difference (LSD) test (t-test). Immediately following the fire, tree-of-heaven had an average percent cover that was significantly higher than both pre-fire and three full growing seasons following the fire (0.030 in 2004 compared to 0.002 and 0.003 in 2003 and 2007, respectively) (Figure 5.3). The same pattern occurred for tree-of-heaven IVs 
(Figure 5.4). Even at its highest point in 2004, tree-of-heaven still only had a mean IV of 0.83 .

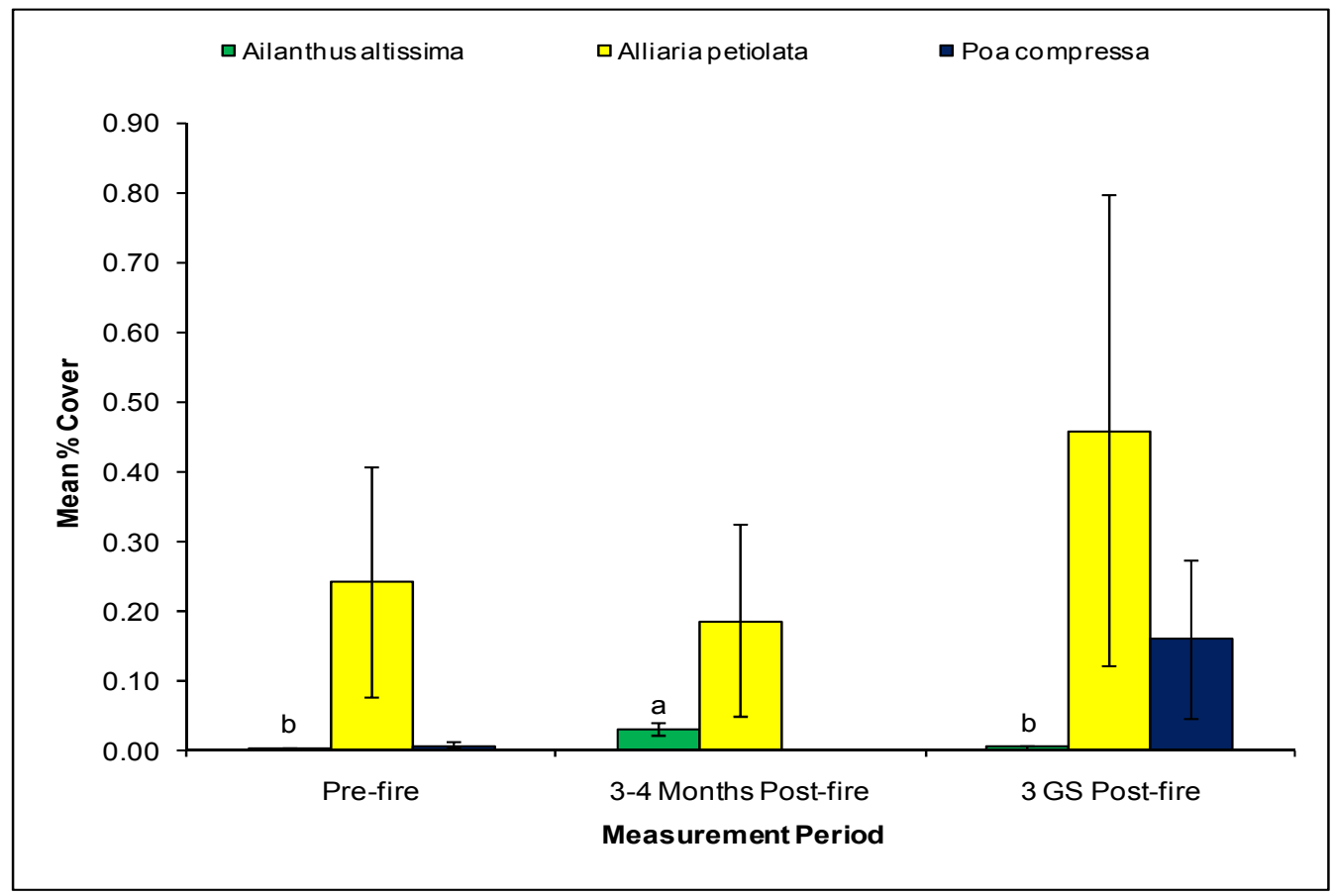

Figure 5.3. Average percent cover by species and measurement period. Means with the same letter are not significantly different at $\alpha=0.05$. Error bars represent $+/$ - one standard error. GS = growing seasons.

\section{$\underline{\text { NMS Ordination }}$}

The NMS ordination (a three dimensional solution) of combined pre- and post-fire abundance data yielded a final stress and instability of 21.79 and 0.032 , respectively. Stress and instability values this high generally do not indicate a reliable solution (McCune and others 2002), therefore the results must be used with caution. 


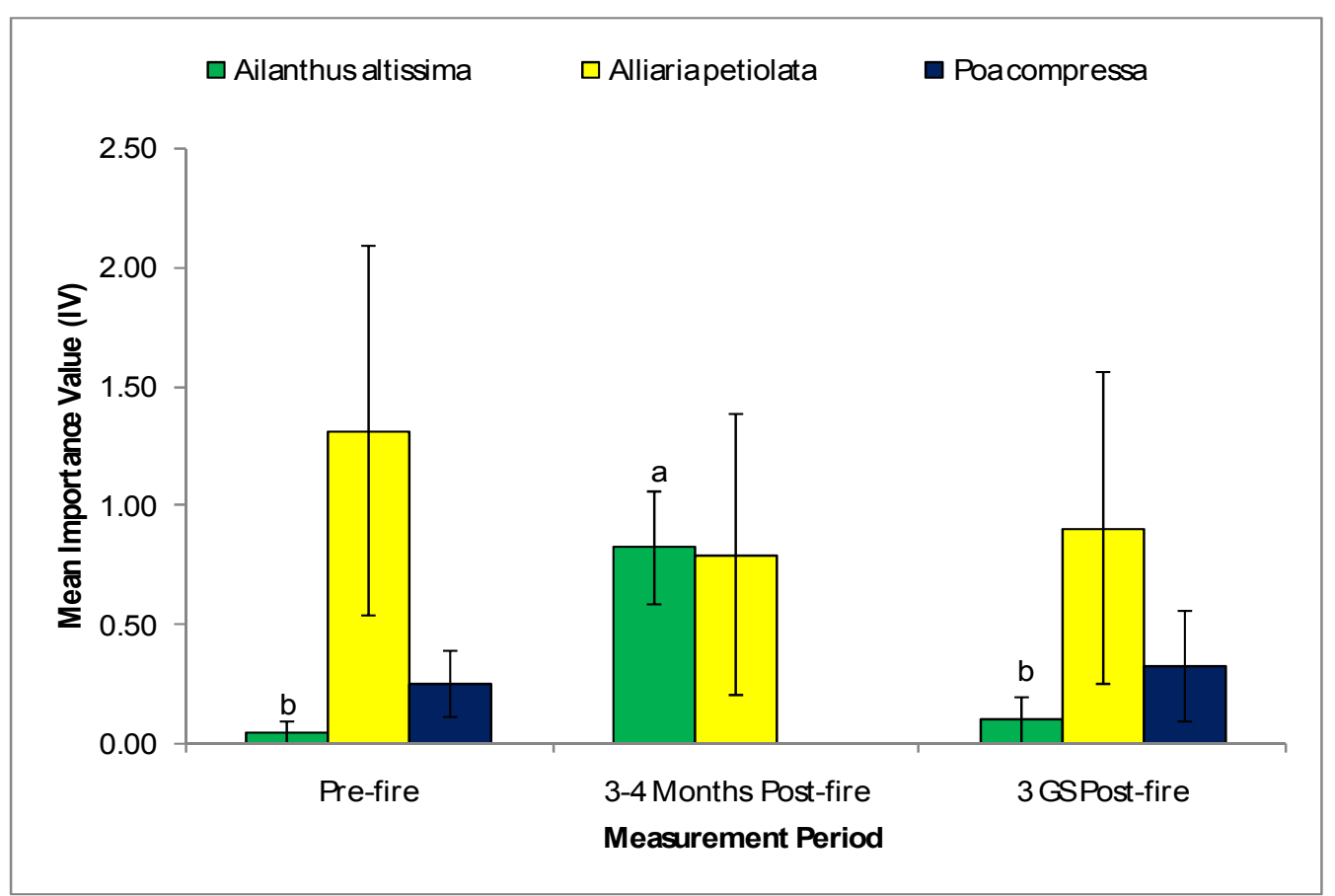

Figure 5.4. Average IV by species and measurement period. Means with the same letter are not significantly different at $\alpha=0.05$. Error bars represent $+/$ one standard error. GS = growing seasons.

Axis 1,2 , and 3 represented $10.5,18.4$, and $17.8 \%$ of the variance in species composition (cumulative $\mathrm{R}^{2}=0.47$ ). Axes 2 and 3 are presented and discussed as they reflected most of the variability in species composition. The NMS results provided further evidence that pre-fire and post-fire understory layers can be characterized by somewhat different species compositions. Graphical inspection identified axis 3 as most influential for separating sampling plots based on the effects of the prescribed fire (Figure 5.5). Interestingly, this axis showed a rather strong negative correlation with percent change in canopy cover $(r=-0.41)$, indicating that canopy cover decreased from pre- to post-fire. 
Axis 3 scores were most positively correlated with striped maple (Acer pensylvanicum L.) $(\mathrm{r}=0.39)$, grape $(\mathrm{r}=0.38)$, and witch-hazel (Hamamelis virginiana L. $)(\mathrm{r}=0.30)$ (Appendix Table 4). Although the Pearson correlation coefficients were rather low, this indicates that these species were greater in abundance prior to the prescribed fire. To some extent this agrees with the ISA results. Grape was a significant indicator of pre-fire understory composition. Although striped maple and witch hazel exhibited a stronger $\mathrm{IV}_{\mathrm{kj}}$ in the pre-fire understory in the ISA, their observed $\mathrm{IV}_{\mathrm{kj}}$, however, did not exceed their expected $\mathrm{IV}_{\mathrm{kj}}$ and were, therefore, not significant indicators. Axis 3 scores were most negatively correlated with common cinquefoil (Potentilla simplex Michx.) (r = 0.61), summer bluets (Houstonia longifolia Gaertn.) $(\mathrm{r}=-0.50)$, and upland low blueberry (Vaccinium pallidum Ait.) (-0.45). These correlations indicate that these species were greater in abundance following the prescribed fire. All three of these species were significant indicators of post-fire composition in the ISA.

The exotic invasive garlic mustard showed only weak positive correlations with axis 3 scores $(r=0.14)$ (Appendix Table 4). Canada bluegrass exhibited a negative correlation $(r=-0.11)$. These exotic invasives showed stronger correlations to axis $2(r=0.45$ for garlic mustard and $\mathrm{r}=0.22$ for Canada bluegrass), suggesting that additional factors are related to their abundance. Species richness was positively correlated with axis 2 scores (Figure 5.5), suggesting that the exotic invasives are in higher abundance in areas where species richness is higher. Sapling mortality was negatively associated with axis 2 , implying that the exotic invasives are in lower abundance in areas where relative fire 
intensity was lower. This also indicates that understory species richness is higher in areas were relative fire intensity was lower.

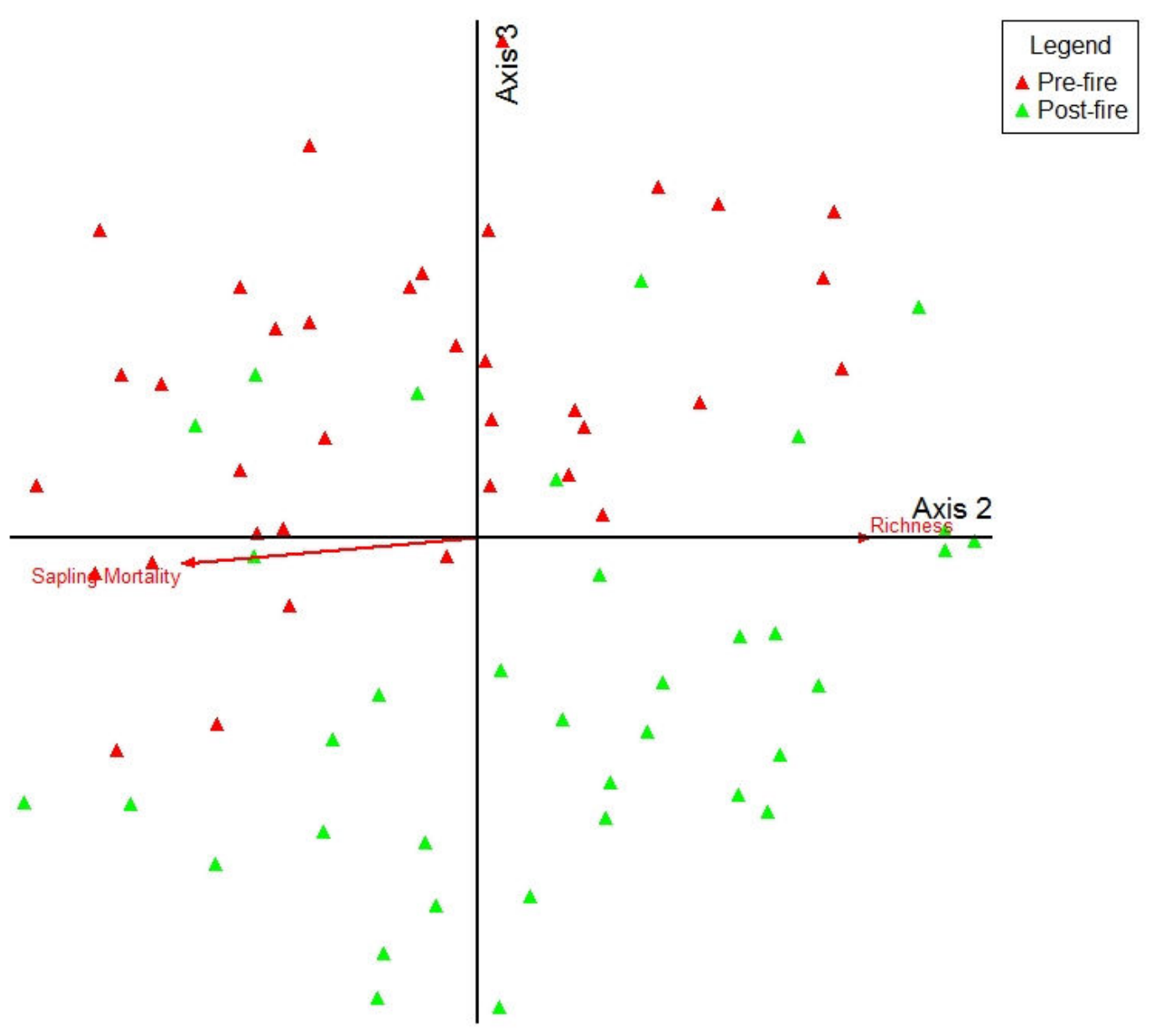

Figure 5.5. NMS ordination (axes 2 and 3) of sample plots (data are understory abundance (percent cover)) before and after the prescribed fire. Vectors showing influential explanatory variables are also shown $\left(R^{2}\right.$ cutoff $\left.=0.20\right)$. 


\section{Exotic Invasive Plant Species and Relative Fire Intensity/Environmental Variables}

\section{NMS Ordination}

The NMS ordination (a two dimensional solution) of post-fire "smoothed" timed meander data yielded a final stress and instability of 9.189 and 0.038 , respectively. Axis 1 and 2 represented 79.0 and $16.0 \%$ of the variance in species composition (cumulative $\mathrm{R}^{2}=0.95$ ). Similar to the results of the NMS ordination of pre- and post-fire abundance data, these NMS results also suggested that sapling mortality and species richness can help explain the variability in species composition across the study site (Figure 5.6). In addition, this ordination also identified mean bole scorch height and TRMI as strong explanatory variables. Average bole scorch height and sapling mortality showed rather strong negative correlations with axis $1(\mathrm{r}=-0.51$ and $\mathrm{r}=-0.42)$. Species richness, on the other hand, exhibited a strong positive correlation with axis $1(\mathrm{r}=0.54)$. This implies that understory species richness is higher in areas where relative fire intensity (expressed by average bole scorch height) was lower and vice versa. Because they are highly correlated (see Chapter 4), it also makes sense that bole scorch height and sapling mortality show similar correlations to axis 1 . TRMI showed a quite strong negative correlation $(r=-0.57)$ with axis 2 scores, while sapling mortality exhibited a moderate positive correlation $(\mathrm{r}=0.41)$. This implies that relative fire intensity (expressed by sapling mortality) was higher in dryer areas and lower in moister areas.

The exotic invasives considered in the analysis showed positive correlations with axis 1 , suggesting a higher "favorability" for these species in areas of higher understory species 
richness and where relative fire intensity was lower (Appendix Table 6). Common sheep sorrel and autumn olive were not considered in the analysis because they occurred in less than five percent of the sample plots. Garlic mustard, tree-of-heaven, Japanese stilt grass, and Canada bluegrass showed correlations of $r=0.86, r=0.75, r=0.48$, and $r=0.42$, respectively, with axis 1 scores. With the exception of Canada bluegrass, negative correlations of these exotic invasives to axis 2 also indicate higher "favorability" in moister areas (Appendix Table 6). Japanese stilt grass "favorability" showed the strongest association with these moister areas $(r=-0.58)$, followed by garlic mustard $(r=$ $-0.56)$ and tree-of-heaven $(r=-0.35)$, respectively. 


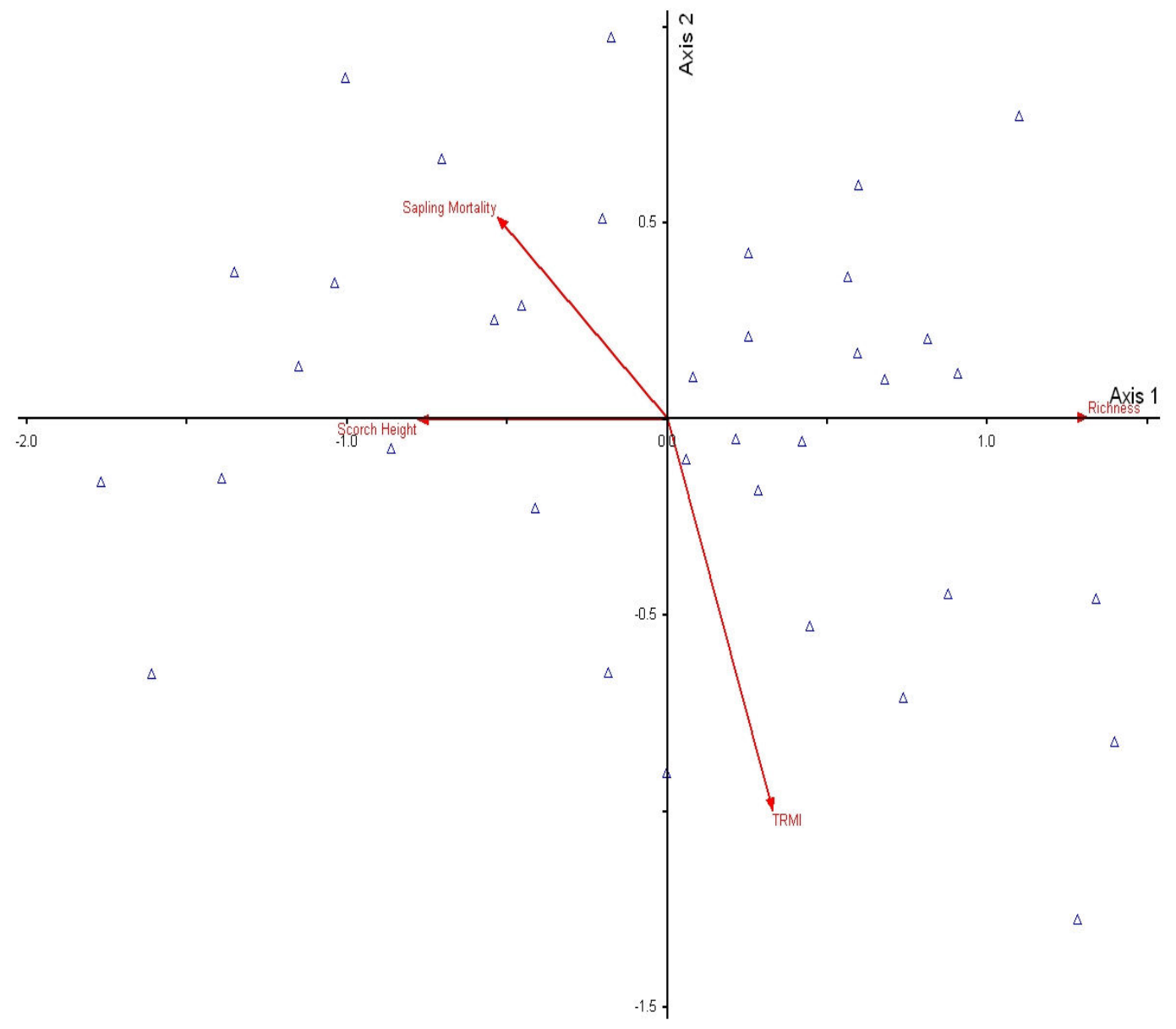

Figure 5.6. NMS ordination (axes 1 and 2) of sample plots (data are "smoothed" understory presence/absence) after the prescribed fire (2007). Vectors showing influential explanatory variables are also shown $\left(R^{2}\right.$ cutoff $\left.=0.20\right)$. 


\section{$\underline{\text { Logistic Regression }}$}

Seven of the environmental variables were statistically significant when evaluated individually (Table 5.2). Five of these seven variables were statistically significant in the multiple logistic regression models (Table 5.3). Neither of the relative fire intensity variables were significant in either the individual or full models. The Hosmer-Lemeshow goodness of fit tests indicated that the estimates for all of the multiple logistic regression models fit the data at an acceptable level (Table 5.3). However, it should be noted that, because of the small sample size in this study, there is an extremely high probability that the multiple logistic regression models are overfit. Hosmer and Lemeshow (2000) suggest that logistic regression models should use no more than $\mathrm{p}+1 \leq \min \left(\mathrm{n}_{1}, \mathrm{n}_{0}\right) / 10$ parameters, where $\mathrm{p}=$ the number of parameters (variables) and $\min \left(\mathrm{n}_{1}, \mathrm{n}_{0}\right)$ is, in this study, the minimum number of plots with either presence or absence of a give exotic invasive species. The results, therefore, should be used with caution.

Elevation was a significant independent variable for all exotic invasive models except garlic mustard. In addition to elevation, distance from harvesting was included in the 2004 (3 - 4 months post-fire) tree-of-heaven multiple logistic regression model. Percent change in canopy cover was a second independent variable included in both the 2007 (three full growing seasons post-fire) tree-of-heaven and Category 1 exotic invasives multiple logistic regression models. Distance from areas where tree-of-heaven has reached the main canopy was the only variable included in the garlic mustard logistic regression model. 
Table 5.2. Results of individual logistic runs for each statistically significant variable.

\begin{tabular}{|c|c|c|c|c|c|}
\hline Model & Independent Variable & MLE & SE & $\mathbf{p}$ & Odds ratio \\
\hline \multirow[t]{2}{*}{ Ailanthus altissima (2004) } & Distance from AA in main canopy (m) & $\begin{array}{c}- \\
0.009 \\
-\end{array}$ & 0.004 & 0.015 & 0.991 \\
\hline & $\begin{array}{l}\text { Distance from harvesting }(\mathrm{m}) \\
\text { Distance from roads }(\mathrm{m}) \\
\text { Elevation }(\mathrm{m})\end{array}$ & $\begin{array}{l}0.120 \\
0.007 \\
0.020\end{array}$ & $\begin{array}{l}0.004 \\
0.002 \\
0.007\end{array}$ & $\begin{array}{l}0.009 \\
0.008 \\
0.003\end{array}$ & $\begin{array}{l}0.988 \\
1.007 \\
1.020\end{array}$ \\
\hline \multirow[t]{3}{*}{ Ailanthus altissima (2007) } & $\begin{array}{c}\text { Distance from roads }(\mathrm{m}) \\
\text { Elevation }(\mathrm{m})\end{array}$ & $\begin{array}{l}0.006 \\
0.017\end{array}$ & $\begin{array}{l}0.003 \\
0.007\end{array}$ & $\begin{array}{l}0.038 \\
0.012\end{array}$ & $\begin{array}{l}1.006 \\
1.017\end{array}$ \\
\hline & Percent canopy cover & 0.105 & 0.050 & 0.038 & 0.900 \\
\hline & Shading (\%) & 0.119 & 0.050 & 0.001 & 0.888 \\
\hline Alliaria petiolata (2007) & $\begin{array}{c}\text { Distance from AA in main canopy }(\mathrm{m}) \\
\text { Distance from roads }(\mathrm{m}) \\
\text { Elevation }(\mathrm{m})\end{array}$ & $\begin{array}{l}0.012 \\
0.007 \\
0.016\end{array}$ & $\begin{array}{l}0.006 \\
0.003 \\
0.007\end{array}$ & $\begin{array}{l}0.035 \\
0.026 \\
0.019\end{array}$ & $\begin{array}{l}0.988 \\
1.007 \\
1.016\end{array}$ \\
\hline \multirow[t]{2}{*}{ Category 1 Exotic Invasives (2007) } & $\begin{array}{c}\text { Distance from AA in main canopy }(\mathrm{m}) \\
\text { Distance from roads }(\mathrm{m}) \\
\text { Elevation }(\mathrm{m}) \\
\text { Shading }(\%)\end{array}$ & $\begin{array}{c}- \\
0.007 \\
0.007 \\
0.020 \\
- \\
0.076\end{array}$ & $\begin{array}{l}0.003 \\
0.003 \\
0.007 \\
0.038\end{array}$ & $\begin{array}{l}0.019 \\
0.005 \\
0.003 \\
0.044\end{array}$ & $\begin{array}{l}0.993 \\
1.007 \\
1.020 \\
0.927\end{array}$ \\
\hline & Species Richness & 0.079 & 0.04 & 0.047 & 1.038 \\
\hline
\end{tabular}

For ease of interpretation, the effects of the independent variables (based on their odds ratios) on the probability of presence for the exotic invasive species are listed in Table 5.4. Every one unit increase in any given independent variable in Table 5.4 is associated with an increase or decrease in the chance of a given exotic invasive species being present in the understory. For example, for the 2004 tree-of-heaven model: every one meter increase in distance from harvesting is associated with a one percent decrease in the likelihood that tree-of-heaven will be present in the understory (Table 5.4). 
Table 5.3. Results of multiple logistic regression models.

\begin{tabular}{|c|c|c|c|c|c|c|c|c|}
\hline Model & Independent Variable & MLE & SE & $\mathbf{p}$ & $\begin{array}{l}\text { Odds } \\
\text { ratio } \\
\end{array}$ & $\mathbf{R}^{2}$ & $\chi^{2}$ & $\mathbf{p}$ \\
\hline Ailanthus altissima (2004) & $\begin{array}{c}\text { Distance from harvesting }(\mathrm{m}) \\
\text { Elevation }(\mathrm{m})\end{array}$ & $\begin{array}{c}- \\
0.012 \\
0.017\end{array}$ & $\begin{array}{l}0.006 \\
0.007\end{array}$ & $\begin{array}{l}0.039 \\
0.013\end{array}$ & $\begin{array}{l}0.988 \\
1.017\end{array}$ & 0.44 & 7.94 & 0.338 \\
\hline Ailanthus altissima (2007) & $\begin{array}{c}\text { Elevation }(\mathrm{m}) \\
\% \Delta \text { in Canopy Cover }\end{array}$ & $\begin{array}{c}0.022 \\
- \\
0.130\end{array}$ & $\begin{array}{l}0.010 \\
0.056\end{array}$ & $\begin{array}{l}0.032 \\
0.021\end{array}$ & $\begin{array}{l}1.022 \\
0.878\end{array}$ & 0.37 & 3.11 & 0.874 \\
\hline Alliaria petiolata (2007) & $\begin{array}{l}\text { Distance from AA in main canopy } \\
(\mathrm{m})\end{array}$ & 0.012 & 0.006 & 0.035 & 0.988 & 0.23 & 12.69 & 0.080 \\
\hline $\begin{array}{l}\text { Category } 1 \text { Exotic Invasives } \\
(2007)\end{array}$ & $\begin{array}{c}\text { Elevation }(\mathrm{m}) \\
\% \Delta \text { in Canopy Cover }\end{array}$ & $\begin{array}{c}0.021 \\
- \\
0.074\end{array}$ & $\begin{array}{l}0.007 \\
0.042\end{array}$ & $\begin{array}{l}0.005 \\
0.081\end{array}$ & $\begin{array}{l}1.021 \\
0.929\end{array}$ & 0.40 & 5.29 & 0.624 \\
\hline
\end{tabular}

Table 5.4. Interpretation of odds ratios. Every one unit increase in any given independent variable is associated with an increase or decrease in the odds (effect) of a given exotic invasive species being present in the understory.

\begin{tabular}{lcc}
\hline Model & Independent Variable & Effect \\
\hline Ailanthus altissima (2004) & Distance from harvesting (m) & $1 \% \downarrow$ \\
& Elevation (m) & $2 \% \uparrow$ \\
Ailanthus altissima (2007) & Elevation (m) & $2 \% \uparrow$ \\
& $\%$ in Canopy Cover & $12 \%$ \\
Alliaria petiolata (2007) & & $\downarrow$ \\
Category 1 Exotic Invasives (2007) & Distance from AA in main canopy (m) & $1 \% \downarrow$ \\
& Elevation (m) & $2 \% \uparrow$ \\
& & $7 \% \downarrow$ \\
\hline
\end{tabular}




\section{Discussion}

Contrary to the findings of other studies (Arthur and others 1998, Bowles and others 2007, Hutchinson and others 2005, Welch and others 2002), species richness was found to be significantly lower $(\mathrm{P}<0.05)$ in the post-fire understory. Marsh $(2005)$ reported a significant increase in overall understory species richness at the same site three to four months post fire. However, understory communities are very dynamic and composition can change within a growing season, and from growing season to growing season following fire (Bowles and others 2007, Hutchinson 2006), as well as other disturbances (Small and McCarthy 2002).

Prior to the application of the prescribed fire, the percentage of exotic invasive plants found on the $1 \mathrm{~m}^{2}$ understory plots was very small when compared to the total number of plants. Four exotic invasive species were recorded prior to the fire in 2003. However, tree-of-heaven and Bell's honeysuckle were found on only one of the 0.05 ha plots. Garlic mustard and tree-of-heaven occurred on the same plot, a plot that was located in an area that was harvested in 1972. Garlic mustard was also found on two other plots prior to the fire, one of which was in a different 1972 harvest area. This is an indication that the harvesting may have played a role in initial establishment of the exotic invasive species. Unfortunately, it is unknown whether or not these species occurred on the study site prior to the harvesting in 1972.

Three full growing seasons after the fire, the percentage of exotic invasive plants found on the $1 \mathrm{~m}^{2}$ understory plots was also very low. Garlic mustard and Canada bluegrass 
were found on the same 0.05 ha plots they were found on prior to the fire, with the exception that Canada bluegrass was found on one less plot.

The timed meander inventory identified the same percentage of post-fire exotic invasives as the $1 \mathrm{~m}^{2}$ plots. However, the results do indicate that, at the Dunkle Knob study site, the timed meander inventory method is superior to the $1 \mathrm{~m}^{2}$ understory plots for documenting true understory species richness, defining true understory flora, and for detecting the true number exotic invasive plants found in the understory. If the understory at Dunkle Knob is to be monitored for exotic invasive species, or simply for compositional changes, following future burns, it is suggested that the timed meander inventory method be employed on the sample plots. However, for this method to be effective over multiple measurement periods, those who conduct the inventory should be skilled in flora identification at the site, which may limit its applicability both in this and in other cases (Huebner 2007). Also, because the timed meander method does not provide a true measure of abundance, the $1 \mathrm{~m}^{2}$ understory plots should still be employed to monitor changes in this measure.

\section{Pre-treatment vs. Post Treatment}

When comparing pre-treatment and post-treatment abundances, neither ISA nor the NMS ordination indicated significance with respect to the exotic invasives. Instead the NMS ordination indicated that abundance of exotic invasives was correlated with areas of higher species richness and lower relative fire intensity. Similarly, other studies have shown that exotic plant invasions are positively associated with higher species richness 
(Bridgewater and Backshall 1981, DeFerrari and Naiman 1994, Huebner and Tobin 2006, Robinson and others 1995). Interestingly, also at the $1 \mathrm{~m}^{2}$ scale, Stohlgren and others (1999) found that higher exotic invasive plants species richness was associated with areas of higher native plant species richness in forests of the Rocky Mountains. The findings of higher exotic invasive abundances in areas of lower fire intensity disagree with those of Glasgow and Matlack (2006). However, exotic invasive plant seeds were added in their study, it took place in a more mesophytic hardwood forest, and they examined two species that did not occur on the $1 \mathrm{~m}^{2}$ plots at the Dunkle Knob study site.

The results of the MRPP, Mantel test, and NMS ordination did, however, suggest that the pre-fire and post-fire understory layers were characterized by somewhat different species composition. However, some of the differences are likely due to inconsistencies in sampling from period to period. For example, the ISA results suggest that pignut hickory is an indicator of post-fire composition, while shagbark hickory (Carya ovata (P. Mill.) K. Koch) is an indicator of pre-fire composition. This is likely a result of misidentification afield during one of the two sampling periods. Changes in investigators, or those who sample the permanent plots, can produce spurious apparent changes (Ketchledge and Leonard 1984, McCune and Menges 1986), especially in the understory where high plant identification skill is required. Based on extensive work with the data, I also feel that although Pinus spp., UK Poaceae, and Vitis spp., in particular, were statistically significant indicators of pre-fire composition, they are not ecologically significant. That is, these species were deemed as indicators due to a grouping or "lumping" effect. Vitis spp. also showed higher abundance pre-fire in the 
NMS ordination. These three species groups were classified to species in many more cases during the post-fire inventory. If the post-fire data were "lumped" into groups that matched the pre-fire groups, or if the pre-fire groups could be broken down to the species level, these results would likely be more reliable.

Nevertheless, the ISA results suggest that the fire resulted in an improvement in regeneration for the chestnut oak and red maple (Acer rubrum L.). The NMS ordination results also suggest a deterioration in striped maple and witch-hazel regeneration. An increase in wildlife forage is also indicated from both the NMS ordination and ISA results due to increases in upland low blueberry. An improvement in oak regeneration following a single low-intensity fire has been previously documented (Kuddes-Fischer and Arthur 2002, Barnes and Van Lear 1998, Adams and Reiske 2001). The study by Kuddes-Fischer and Arthur (2002) also reported an increase in red maple seedling density. Blankenship and Arthur (2006) also observed abundant red maple regeneration following fire in oak stands in Kentucky. Because upland low blueberry is well adapted to fire (Tirmenstein 1991), it is not surprising to see a greater than expected fidelity to the post-fire understory for this species. Information of the effects of fire on striped maple is lacking, however, its physiological traits would suggest abundant sprouting from dead stems following fire. This, however, was not apparent from the data or from field observations. Witch-hazel is low in resistance and readily killed by fire (Coladonato 1993). 
The ANOVA indicated that tree-of-heaven increased in both abundance and importance immediately following the fire, but was back to pre-fire levels after three full growing seasons. Interestingly, tree of heaven seedlings were recorded on eleven of the 0.05 ha plots (data from the $1 \mathrm{~m}^{2}$ plots) in 2004, compared to only one in 2003 and 2007. Immediate post-fire increases in seedlings likely came from large seed producing female trees located on or near the study site. Tree-of-heaven employs minimal seed banking (Kowarik 1995) and, if large seed producing females exist, most post-fire establishment would likely be by seed (Huebner 2006). Furthermore, tree-of-heaven seed can be dispersed as far as 200 meters from the female parent (Kota 2005). The seedlings would have benefited from decreased competition for light or mineral resources because the fire had killed or "knocked back" pre-existing vegetation (Adams and others 1994, Boerner and others 2000). Given the xeric nature of the Dunkle Knob study site, native vegetation, in particular those species that showed higher abundances post-fire from the ISA and NMS ordination, would soon re-sprout and out compete the tree-of-heaven seedlings for required resources. Studies that directly assess the effect of fire on tree-ofheaven do not exist. However, Huebner (2006) suggests that, if large seed producers exist, tree-of-heaven may increase in abundance with repeated burning. The results from the Dunkle Knob study site cannot confirm this hypothesis because only a single fire was applied to the area.

\section{Exotic Invasive Plant Species and Relative Fire Intensity/Environmental Variables}

Similar to the results of the NMS ordination of pre-fire and post-fire data, the NMS ordination of "smoothed" presence/absence data indicated that areas where relative fire 
intensity was lower and understory species richness was higher were more "favorable" for the exotic invasive species. Garlic mustard and tree-of-heaven showed the strongest relationships with this pattern $(\mathrm{r}>0.74)$ (Appendix Table 6). TRMI was also an influential independent variable in this NMS ordination. Higher soil moisture and fertility often provide higher understory species richness (Small and McCarthy 2002) and, furthermore, relative fire intensity would tend to be lower in areas of higher soil and litter layer moisture. This suggests that, higher moisture (expressed by TRMI), not higher species richness, is likely the direct cause of higher abundances of exotic invasive plants. Small and McCarthy (2002) noted that the frequency of non-native understory species was greater in moister areas relative to drier areas in an oak forest of the central Appalachians.

Despite the possibility of overfitting, the results of the multiple logistic regression models provided some interesting findings. The relative fire intensity variables were not important in determining the probability of presence of the exotic invasive species in the understory of the study site. Instead, the presence of understory exotic invasives was found to be closely related to environmental variables. Elevation was a significant explanatory variable for all exotic invasive species, except garlic mustard, with a higher probability of presence as elevation increases. This relationship was contrary to results the post-fire NMS ordination, which indicated that moister areas provided favorable microsites for the exotic invasive species. It is well known that on a mountain such as Dunkle Knob, lower slopes have more moisture available for plant use relative to upper slopes. Furthermore, no published studies have documented increases in understory 
exotic invasives with increasing elevation. This anomaly may be a result of the combination of increased sampling density near the top of Dunkle Knob (Figure 5.1) and the possible overfitting of the logistic regression models due to a low number of presence observations.

In addition to elevation, both the 2007 tree-of-heaven and Category 1 exotic invasive models also indicated a higher probability of presence where canopy cover has decreased over the last four years. The 2004 tree-of-heaven model also included distance from harvesting as a significant explanatory variable (negative relationship). Tree-of-heaven can tolerate a wide range of environmental conditions (Howard 2004). Several list the species as being shade intolerant (Bourdeau and Laverick 1958, Forgione 1993, Kowarik 1995) and it is often associated with areas of disturbance relative to undisturbed areas (Call and Nilsen 2003, Huebner 2003). Forest disturbances, natural or anthropogenic, generally decrease canopy cover and increase understory light, which, in turn, tends to promote invasion by exotic plant species (Bossard 1991, D’Antonio 1993, Hobbs and Huenneke 1992, Hutchinson and others 2004).

Interestingly, the only significant explanatory variable in the garlic mustard model was distance from areas where tree-of-heaven has reached the main canopy. No published studies have documented this phenomenon, but it is likely that is a result of these areas being associated with disturbance (see Chapter 3). Given the highly invasive nature of these species, coupled with the fact that both possess allelopathic properties (Heisey 1996, McCarthy and Hanson 1998), this suggests that these areas have the potential to be 
very troublesome to native understory vegetation in the future. That is, the understory in areas where tree-of-heaven has reached the main canopy may soon be dominated by treeof-heaven suckers and garlic mustard. Native understory plants, as well as the benefits they provide (e.g. biodiversity, food for wildlife), could be severely impacted in these localized areas.

\section{Sampling Limitations}

The location of sampling and sampling methodology employed in this study likely biased the results. A more systematic inventory, employing cruise line perpendicular to topography and more sample plots, would likely produce less conservative estimates of compositional parameters, limit bias, and generate more indicative results. In an area as large as Dunkle Knob (313.6 ha), a much greater number of plots would be required for high confidence in estimates (Avery and Burkhart 2002, Shiver and Borders 1996). Furthermore, it should be emphasized that the understory abundance measures used in the analyses were the average of four $1 \mathrm{~m}^{2}$ plots on each 0.05 ha plot. Averaging percent cover measurements likely masked significant variability among understory vegetation within the 0.05 ha plots. Also, delineating and sampling within stand types would also allow for improved results and conclusions because exotic invasives appeared to be associated with certain stand types over others (e.g. cove communities versus table mountain/pitch pine communities (J. Pomp, personal observation). Moreover, fire intensity groupings or the use of a control site (burn versus no burn) would certainly have benefited this study. 


\section{Conclusions and Management Implications}

The results of this study indicate that the prescribed fire had little effect on the populations of understory exotic invasive plants. Both exotic invasive abundance and importance was, in general, rather low both before and after the prescribed fire treatment. Tree-of-heaven was the only exotic invasive that showed significantly higher abundance and importance following the prescribed fire. This increase, however, was short-lived. Nevertheless, given the limitations of this study, prescribed fire managers in the Ridge and Valley area should attempt to locate exotic invasive plant "hot spots," especially treeof-heaven, and, if economically feasible, eradicate them prior to applying a burn. Effective chemical control methods are available for controlling a majority of the unwanted exotic invaders found in this study (tree-of-heaven (Eck 2005), Japanese stilt grass (Pomp and others, In Press), garlic mustard (Nuzzo 1991), Canada bluegrass (Waller and Schmidt 1983), and autumn olive (Kuhns 1986). Pre-fire control of exotic invasive species would aim to make the forest more resilient to further invasion, reduce the likelihood of post-fire establishment, and help protect native understories and the future of eastern oak and pine forest communities, as well as the ecological benefits they provide.

Although the prescribed fire induced changes in understory vegetation, the results suggest that environmental factors play more of a role in determining the location and abundance of exotic invasives at the Dunkle Knob study site. Furthermore, prior harvesting, and road construction associated with it, undoubtedly played a role in the initial establishment of the exotic invasives. It is highly likely that responses exhibited by exotic invasive 
plant populations, with respect to fire, will be different in dissimilar areas, or even on similar sites within the Ridge and Valley Physiographic Province. That is, due to differences in prior disturbances and the number and abundance of exotic invasive species present, the effects of prescribed fire on exotic invasive plants will be highly site and species specific. Clearly, however, more research is needed on this topic for it to be fully understood. Investigation of multiple burns, fire intensity groupings, and burning during different seasons would undoubtedly better our understanding of the effect of prescribed fire on understory exotic invasive plant species in xeric mixed-oak and oakpine forests of the Appalachians. 


\section{Literature Cited}

Abrams, M. D. 1992. Fire and the development of oak forests. Bioscience. 42(5): 346353.

Adams, A. S.; Rieske, L. K. 2001. Herbivory and fire influence white oak. Quercus alba L. seedling vigor. Forest Science. 47(3): 331-337.

Adams, M. A.; Iser, J.; Keleher, A.D.; Cheal D. C. 1994. Nitrogen and phosphorous availability and the role of fire in heathlands at Wilson's promontory. Australian Journal of Botany. 42: 269-278.

Arthur, M. A.; Paratley, R. D.; Blankenship, B. A. 1998. Single and repeated fires affect survival and regeneration of woody and herbaceous species in an oak-pine forest. Journal of the Torrey Botanical Society. 125: 225-236.

Avery, T. E.; Burkhart, H. E. 2002. Forest Measurements, $5^{\text {th }}$. Edition. New York, NY: McGraw-Hill, Inc. 456p.

Barden, L. S.; Woods, F. W. 1976. Effects of fire on pine and pine hardwood forests in the southern Appalachians. Forest Science. 22(4): 399-403.

Beals, E. W. 1984. Bray-Curtis Ordination: an effective strategy for analysis of multivariate ecological data. Advances in Ecological Research. 14: 1-55.

Blankenship, B. A.; Arthur, M. A. 2006. Stand structure over 9 years in burned and fireexcluded oak stands in the Cumberland Plateau, Kentucky. Forest Ecology and Management. 225: 134-145.

Boerner, R. E. J.; Sutherland, E. K.; Morris, S. J.; Hutchinson, T. F. 2000. Spatial variation in the effect of prescribed fire on $\mathrm{N}$ dynamics in a forested landscape. Landscape Ecology. 15: 425-439.

Bourdeau, P. F.; Laverick, M. L. 1958. Tolerance and photosynthetic adaptability to light intensity in white pine, red pine, hemlock, and ailanthus seedlings. Forest Science. 4(3): 196-207.

Bossard, C. C. 1991. The role of habitat disturbance, seed predation, and ant dispersal on establishment of the exotic shrub Cytisus scoparius in California. American Midland Naturalist. 126(1): 1-13.

Bowles, M. L.; Jacobs, K. A.; Mengler, J. L. 2007. Long-term changes in an oak forest's woody understory and herb layer with repeated burning. Journal of the Torrey Botanical Society. 134(2): 223-237.

Braun, E.L. 1950. Deciduous forests of eastern North America. New York, NY: 
Macmillan. 596p.

Bridgewater, P. B.; Backshall, D. J. 1981. Dynamics of some Western Australian ligneous formations with special reference to the invasion of exotic species. Vegetatio. 46: 141-148.

Brooks, M. L.; D’Antonio, D. M.; Richardson, D. M. [and others]. 2004. Effects of invasive alien plants on fire regimes. BioScience. 54(7): 677-688.

Brose, P. H.; Schuler, T. M.; Van Lear, D; Berst, J. 2001. Bringing fire back: the changing regimes of the Appalachian mixed-oak forests. Journal of Forestry. 99(11): 30-35.

Brose, P. H.; Waldrop, T. A. 2006a. Fire and the origin of table mountain pine - pitch pine communities in the southern Appalachian Mountains, USA. Canadian Journal of Forest Research. 36: 710-718.

Brose, P. H.; Waldrop, T. A. 2006b. Changes in the disturbance regime of upland yellow pine stands in the southern Appalachian Mountains during the $20^{\text {th }}$ century. USDA Forest Service, Gen. Tech. Rep. SRS-92.

Cain, M.D. 1984. Height of stem-bark char underestimates flame length in prescribed burns. USDA Forest Service Fire Management Notes. 45: 17-21.

Call, L. J.; Nilsen, E. T. 2003. Analysis of spatial patterns and spatial association between the invasive exotic tree-of-heaven (Ailanthus altissima) and the native black locust (Robinia pseudoacacia). The American Midland Naturalist. 150(1): $1-14$.

Coladonato, M. 1993. Hamamelis virginiana. In: Fire Effects Information System. http://www.fs.fed.us/database/feis/. USDA Forest Service, Rocky Mountain Research Station, Fire Sciences Laboratory (producer). [Date Accessed: March 1, 2008].

Core, E.L. 1966. Vegetation of West Virginia. Parsons, WV: McClain Printing Company. $1077 \mathrm{p}$.

Crawford, J. A.; Wahren, C.-H. A.; Kyle, S.; Moir, W. H. 2001. Responses of exotic plant species to fires in Pinus ponderosa forests in northern Arizona. Journal of Vegetation Science. 12: 261-268.

D'Antonio, C. M. 1993. Mechanisms controlling invasion of coastal plant communities by the alien succulent Carpobrotus edulis. Ecology. 74: 83-95.

D’Antonio, C. M.; Vitousek, P. M. 1992. Biological invasions by exotic grasses, the 
grass/fire cycle, and global change. Annual Review of Ecological Systems. 23: 63-87.

DeFerrari, C. M.; Naiman, R. J. 1994. A multi-scale assessment of the occurrence of exotic plants on the Olympic Peninsula, Washington. Journal of Vegetation Science. 5: 247-258.

De Grandpré, L.; Morissette, J.; Gauthier, S. 2000. Long-term post-fire changes in the northeastern boreal forest of Quebec. Journal of Vegetation Science. 11: 791800 .

Doren, R. F.; Whiteaker, L. D. 1990. Effects of fire on different size individuals of Schinus terebinthifolius. Natural Areas Journal. 10(3): 107-113.

Dufrene, M.; Legendre, P. Species assemblages and indicator species: the need for a flexible asymmetrical approach. Ecological Monographs. 67: 345-366.

Eck, W. E. 2005. Investigating treatment windows for effective and environmentally sound herbicide applications for controlling tree-of-heaven. Morgantown, WV: West Virginia University. 61p. M.S. Thesis.

Elliot, K. J.; Hendrick, R. L.; Major, A.E. 1999. Vegetation dynamics after a prescribed fire in the southern Appalachians. Forest Ecology and Management. 114: 199213.

Estepp, R. 1992. Soil Survey of Pendleton County, West Virginia. U.S. Soil Conservation Service.

Forgione, H. M. 1993. Limits to the establishment and growth of tree-of-heaven explored. Restoration and Management Notes. 11(1): 70-71.

Glasgow, L. S.; Matlack, G. R. 2007. The effects of prescribed burning and canopy openness on establishment of two non-native plant species in a deciduous forest, southeast, Ohio, USA. Forest Ecology and Management. 238: 319-329.

Gleason, H. A.; Cronquist, A. 1991. Manual of the Vascular Plants of the Northeastern United States and Adjacent Canada, $2^{\text {nd }}$. Edition. Bronx, NY: The New York Botanical Garden. 910p.

Goff, F. G.; Dawson, G. A.; Rochow, J. J. 1982. Site examination for threatened and endangered plants. Environmental Management. 6(4): 307-316.

Griffis, K. L.; Crawford, J. A.; Wagner, M. R.; Moir, W. H. 2001. Understory response to management treatments in northern Arizona ponderosa pine forests. Forest Ecology and Management. 146: 239-245. 
Harmon, M. E. 1982. Fire history of the westernmost portion of Great Smoky Mountains National Park. Bulletin of the Torrey Botanical Club. 109: 74-79.

Harmon, P. J.; Ford-Werntz, D.; Grafton, W. 2006. Checklist and Atlas of the Vascular Flora of West Virginia. West Virginia Division of Natural Resources, Wildlife Resources Section, Elkins, WV. 381 p.

Hartman, K. M.; McCarthy, B. C. 2007. A dendro-ecological study of forest overstorey productivity following the invasion of the non-indigenous shrub Lonicera maackii. Applied Vegetation Science. 10: 3-14.

Heisey, R. M. 1996. Identifications of an allelopathic compound from Ailanthus altissima (Simaroubaceae) and characterization of its herbicidal activity. American Journal of Botany. 83: 192-200.

Hester, A. J.; Hobbs, R. J. 1992. Influence of fire and soil nutrients on native and nonnative annuals at remnant vegetation edges in the Western Australian Wheatbelt. Journal of Vegetation Science. 3(1): 101-108.

Hobbs, R. J.; Huenneke, L. F. 1992. Disturbance, diversity, and invasion: implications for conservation. Conservation Biology. 6(3): 324-337.

Hosmer, D. W.; Lemeshow, S. L. 1980. A goodness-of-fit test for the multiple logistic regression model. Communications in Statistics. A10: 1043-1069.

Hosmer, D. W.; Lemeshow, S. L. 2000. Applied Logistic Regression, $2^{\text {nd }}$. Edition. New York, NY: John Wiley and Sons, Inc. 375p.

Howard, J. L. 2004. Ailanthus altissima. In: Fire Effects Information System. http://www.fs.fed.us/database/feis/. USDA Forest Service, Rocky Mountain Research Station, Fire Sciences Laboratory (producer). [Date Accessed: March 2, 2008].

Huebner, C. D. 2007. Detection and monitoring of invasive exotic plants: a comparison of four sampling methods. Northeastern Naturalist. 14(2): 183-206.

Huebner, C. D. 2006. Fire and invasive exotic plant species in eastern oak communities: an assessment of current knowledge. In: Dickinson, M. B., ed. 2006. Fire in eastern oak forests: delivering science to land managers, proceedings of a conference. USDA Forest Service Gen. Tech. Rep. NRS-P-1.

Huebner, C. D. 2003. Vulnerability of oak-dominated forests in West Virginia to invasive exotic plants: temporal and spatial patterns of nine exotic species using herbarium records and land classification data. Castanea. 68(1): 1-14.

Huebner, C. D.; Tobin, P. C. 2006. Invasibility of mature and 15-year-old deciduous 
forests by exotic plants. Plant Ecology. 186: 57-68.

Hutchinson, T. 2006. Fire and the herbaceous layer of eastern oak forests In: Dickinson, M. B., ed. 2006. Fire in eastern oak forests: delivering science to land managers, proceedings of a conference. USDA Forest Service Gen. Tech. Rep. NRS-P-1.

Hutchinson, T. F.; Boerner, E. J.; Sutherland, S.; [and others]. 2005. Prescribed fire effects on the herbaceous layer of mixed-oak forests. Canadian Journal of Forest Research. 35: 877-890.

Hutchinson, T. F.; Rebbeck, J.; Long, R. 2004. Abundant establishment of Ailanthus altissima (tree-of-heaven) after restoration treatments in an upland oak forest. In: Yaussy, D. A.; Hix, D. M.; Long, R. P.; Goebel, C. P., eds. Proceedings of the $14^{\text {th }}$ Central Hardwoods Forest Conference. USDA Forest Service, Gen. Tech. Rep. NE-316.

Integrated Taxonomic Information System (ITIS). 2001. The Integrated Taxonomic Information System on line database. http://www.itis.gov. [Date accessed: October 25, 2007].

Ketchledge, E. H.; Leonard, R. E. 1984. A 24-year comparison of the vegetation of an Adirondack mountain summit. Rhodora. 86: 439-444.

Kota, N. L. 2005. Comparative seed dispersal, seedling establishment, and growth of exotic, invasive Ailanthus altissima (Mill.) Swingle and native Liriodendron tulipifera (L.). Morgantown, WV: West Virginia University. 108p. M.S. Thesis.

Kowarik, I. 1995. Clonal growth in Ailanthus altissima on a natural site in West Virginia. Journal of Vegetation Science. 6: 853-856.

Kuddes-Fischer, L. M.; Arthur, M. A. 2002. Response of understory vegetation and tree regeneration to a single prescribed fire in oak-pine forests. Natural Areas Journal. 22(1): 43-52.

Kuhns, L. J. 1986. Controlling autumn olive with herbicides. In Proceedings: The 40th Annual Meeting of the Northeastern Weed Science Society. Pp. 289-294. The Northeastern Weed Science Society. Available on-line: http://www.newss.org/proceedings/proceedings_1986_vol40.pdf.

Lafon, C. W.; Grissino-Mayer, H. D. In Press. Spatial patterns of fire occurrence in the central Appalachian Mountains and its implications for wildland fire management. Physical Geography.

Lafon, C. W.; Hoss, J. A.; Grissino-Mayer, H. D. 2005. The contemporary fire regime of the central Appalachian Mountains and its relation to climate. Physical Geography. 26(2): 126-146. 
Larson, D. L. 2003. Native weeds and exotic plants: relationships to disturbance in mixed-grass prairie. Plant Ecology. 169: 317-333.

Laughlin, D. C.; Bakker, J. D.; Stoddard, M. T.; [and others]. 2004. Toward reference conditions: wildfire effects on flora in an old-growth ponderosa pine forest. Forest Ecology and Management. 199: 137-152.

Loomis, R.M. 1973. Estimating fire-caused mortality and injury in oak-hickory forests. Research Paper NC-94. St. Paul, MN: USDA Forest Service, North Central Forest Experiment Station.

Mack, M. C.; D'Antonio, C. M. 1998. Impacts of biological invasions on disturbance regimes. TREE. 13(5): 195-198.

Mantel, N. 1967. The detection of disease clustering and generalized regression approach. Cancer Research. 27: 209-220.

Marsh, M. A. 2005. Floristic dynamics of Appalachian pine-oak forests over a prescribed fire chronosequence. Morgantown, WV: West Virginia University. 275p. M.S. Thesis.

Maxwell, R. S. 2006. Establishing a historic benchmark for rimrock pine communities at New River Gorge National River, West Virginia. Morgantown, WV: West Virginia University. 97p. M.S. Thesis.

McCarthy, B. C.; Hanson, S. L. 1998. An assessment of the allelopathic potential of the invasive weed Alliaria petiolata (Brassicaceae). Castanea. 63: 68-73.

McCune, B.; Grace, J. B.; Urban, D. L. 2002. Analysis of Ecological Communities. Gleneden Beach, Oregon: MjM Software Design. 300p.

McCune, B.; Mefford. 1999. PC-ORD. Multivariate Analysis of Ecological Data. Version 5.0. MjM Software, Gleneden Beach, Oregon, USA.

McCune, B.; Menges, E. S. 1986. Quality of historical data on midwestern old-growth forests. American Midland Naturalist. 116: 163-172.

Mlot, C. 2003. Invasive Species West Virginia. Cambridge, MA: Union of Concerned Scientists.

Mooney, H. A.; Hobbs, R. J. 2000. Invasive Species in a Changing World. Washington, D.C.: Island Press.

Nuzzo, V. A. 1991. Experimental control of garlic mustard [Alliaria petiolata (Bieb.) 
Carva \& Grande] in northern Illinois using fire, herbicide, and cutting. Natural Areas Journal. 11: 158-167.

Nuzzo, V. A; McClain, W.; Strole, T. 1996. Fire impact on groundlayer flora in a sand forest 1990-1994. American Midland Naturalist. 136(2): 207-221.

Parker, A. J. 1982. The topographic relative moisture index: an approach to soil moisture assessment in mountain terrain. Physical Geography. 3(2): 160-168.

Pomp, J.; McGill, D.; Grafton, W; [and others]. In Press. Effects of mechanical and chemical control on Microstegium vimineum and its associates in central West Virginia. In Proceedings: $14^{\text {th }}$ Biennial Southern Silviculture Research Conference, Athens, GA. February 2007. USDA Forest Service, Southern Research Station, Asheville, NC.

Pyle, L. L. 1995. Effects of disturbance on herbaceous exotic plant species on the floodplain of the Potomac River. American Midland Naturalist. 134: 244-253.

Regelbrugge, J.C.; Conrad, S.G. 1993. Modeling tree mortality following wildfire in Pinus ponderosa forests in the central Sierra Nevada of California. International Journal of Wildland Fire. 3(3): 139-148.

Regelbrugge, J.C.; Smith, D.W. 1994. Postfire tree mortality in relation to wildfire severity in mixed oak forests in the Blue Ridge of Virginia. Northern Journal of Applied Forestry. 11(3): 90-97.

Rentch, J. S.; Fortney, R. H.; Stephenson, S. L.; [and others]. 2005. Vegetation-site relationships of roadside plant communities in West Virginia, USA. Journal of Applied Ecology. 42: 129-138.

Rentch, J. S.; Hicks, R. R, Jr. 2003. Canopy disturbance intervals, early growth rates, and canopy accession trends of oak-dominated old-growth forests. In: Van Sambeek, J. W.; Dawson, J. O.; Ponder, F, Jr.; [and others]., eds. Proceedings of the $13^{\text {th }}$ Central Hardwood Forest Conference. USDA Forest Service, Gen. Tech. Rep. NC-234.

Rice, P. M. 2005. Fire as a tool for controlling nonnative invasive plants. www.weedcenter.org/management/tools.htm\#burning. Bozeman, MT: Center for Invasive Plant Management.

Robinson, G. R.; Quinn, J. F.; Stanton, M. L. 1995. Invasibility of experimental habitat islands in a California winter annual grassland. Ecology. 76: 786-794.

SAS Institute Inc. 2003. SAS/ETS user's guide. Version 8.2. $2^{\text {d }}$ ed. Cary, NC: SAS Institute Inc. $956 \mathrm{p}$. 
Schuler, T. M. 2004. Fifty years of partial harvesting in a mixed mesophytic forest: composition and productivity. Canadian Journal of Forest Research. 34: 985997.

Schuler, T. M.; McClain, W. R. 2003. Fire history of a Ridge and Valley oak forest. USDA Forest Service, Res. Pap. NE-724.

Shiver, B. D.; Borders, B. E. 1996. Sampling Techniques for Forest Resource Inventory. New York, NY: John Wiley and Sons, Inc. 356p.

Shumway, D. L.; Abrams, M. D.; Ruffner, C. M. 2001. A 400-year history of fire and oak recruitment in an old-growth forest in western Maryland, U.S.A. Canadian Journal of Forest Research. 31: 1437-1443.

Small, C. J.; McCarthy, B. C. 2002. Spatial and temporal variation in the response of understory vegetation to disturbance in a central Appalachian oak forest. Journal of the Torrey Botanical Society. 129(2): 136-153.

Southern Appalachian Man and the Biosphere (SAMAB). 1996. The southern Appalachian assessment terrestrial technical report. USDA Forest Service, Rep. 5 .

Stapanian, M. A.; Sundberg, S. D.; Baumgardner, G. A.; Liston, A. 1998. Alien plant species composition and associations with anthropogenic disturbance in North American forests. Plant Ecology. 139: 49-62.

Stohlgren, T. J.; Binkley, D; Chong, G. W.; [and others]. 1999. Exotic plant species invade hot spots of native plant diversity. Ecological Monographs. 69(1): 25-46.

Sutherland, E. K.; Grissino-Mayer, H. D.; Woodhouse, C. A.; [and others]. 1995. Two centuries of fire in a southwestern Virginia Pinus pungens community. In Proceedings: IUFRO Conference on Inventory and Management in the Context of Catastrophic Events: Altered States of the Forest, University Park, PA. 21-24 June 1993. Pennsylvania State University, Center of Statistical Ecology and Environmental Statistics, University Park, PA.

The Bugwood Network; USDA Forest Service; USDA APHIS PPQ. 2006. Invasive and Exotic Weeds. 1p. http://www.invasive.org/weeds.cfm. [Date accessed: November 12, 2007].

Thomas-Van Gundy, M. T.; Nowacki, G. J.; Schuler, T. M. 2007. Rule-based mapping of fire adapted vegetation and fire regimes for the Monongahela National Forest. USDA Forest Service, Gen. Tech. Rep. NRS-12.

Tirmenstein, D. A. 1991. Vaccinium pallidum. In: Fire Effects Information System. 
http://www.fs.fed.us/database/feis/. USDA Forest Service, Rocky Mountain Research Station, Fire Sciences Laboratory (producer). [Date Accessed: March 1, 2008].

USDA Forest Service, Eastern Region. 1998. Section 3B. Eastern region invasive plants, ranked by degree of invasiveness as based on information from states. $1 \mathrm{p}$. http://www.fs.fed.us/r9/wildlife/range/weed/Sec3B.htm. [Date Accessed: February 15, 2008].

Vitousek, P. M.; Walker, L. R. 1989. Biological invasions by Myricacia faya in Hawaii: plant demography, nitrogen fixation, ecosystem effects. Ecological Monographs. 59: 247-265.

Waldrop, T. A.; Mohr, H. H.; Brose, P. H. 2006. Early dynamics of table mountain pine stands following stand-replacement prescribed fires of varying intensity. USDA Forest Service, Gen. Tech. Rep. SRS-92.

Waller, S. S.; Schmidt, D. K. 1983. Improvement of eastern Nebraska tallgrass range using atrazine or glyphosate. Journal of Range Management. 36(1): 87-90.

Wein, R. W.; Wein, G.; Bahret, S.; Cody, W. J. 1992. Northward invading non-native vascular plant species in and adjacent to Wood Buffalo National Park, Canada. Canadian Field-Naturalist. 106(2): 216-224.

Welch, N. T.; Waldrop, T. A.; Buckner, E. R. 2000. Response of southern Appalachian table mountain pine (Pinus pungens) and pitch pine ( $P$. rigida) stands to prescribed burning. Forest Ecology and Management. 136: 185-197.

Williams, C.E. 1998. History and status of table mountain pine-pitch pine forests of the southern Appalachian mountains (U.S.A.). Natural Areas Journal. 18: 81-90.

Williams, C. E.; Johnson, C. W. 1990. Age structure and the maintenance of Pinus pungens in pine-oak forests of southwestern Virginia. American Midland Naturalist. 124(1): 130-141.

Wyant, J.G.; Omi, P.N.; Laven, R.D. 1986. Fire induced tree mortality in a Colorado ponderosa pine/Douglas-fir stand. Forest Science. 32: 49-59.

Yarnell, S. L. 1998. The southern Appalachians: a history of the landscape. USDA Forest Service, Gen. Tech. Rep. SRS-18.

Zimmerman, G. M.; Goetz, H.; Mielke, P. W., Jr. 1985. Use of an improved statistical method for group comparisons to study effects of prairie fire. Ecology. 66(2): 606-611. 


\section{APPENDIX}




\section{TABLE OF CONTENTS}

Table 1. Pre-fire (2003) understory layer vascular plants encountered on $1 \mathrm{~m}^{2}$ plots $(\mathrm{n}=144) \ldots \ldots$.

Table 2. Post-fire (2007) understory layer vascular plants encountered on $1 \mathrm{~m}^{2}$ plots $(\mathrm{n}=144) \ldots .$.

Table 3. Post-fire (2007) understory layer vascular plants encountered during the timed meander inventory $(\mathrm{n}=36)$ .161

Table 4. Pearson correlations for each understory species with axes 2 and 3 of the NMS ordination of combined pre- and post-fire abundance data

Table 5. Pearson correlations for each understory species with axes 1 and 2 of the NMS ordination of "smoothed" post-fire presence/absence data 
Table 1. Pre-fire (2003) understory layer vascular plants encountered on $1 \mathrm{~m}^{2}$ plots $(\mathrm{n}=144)$. UK $=$ unknown.

\begin{tabular}{|c|c|c|c|}
\hline Scientific Name & Habit & $\begin{array}{c}\text { Functional } \\
\text { Type }\end{array}$ & Duration \\
\hline Acer pensylvanicum & Tree & Native Weed & Perennial \\
\hline Acer rubrum & Tree & Native Weed & Perennial \\
\hline Ageratina altissima var. altissima & Ferns and Forbs & Native Weed & Perennial \\
\hline Ailanthus altissima & Tree & Exotic Invasive & Perennial \\
\hline Alliaria petiolata & Ferns and Forbs & Exotic Invasive & Annual \\
\hline Allium cernuum & Ferns and Forbs & Native & Perennial \\
\hline Allium cf. cernuum & Ferns and Forbs & Native? & Perennial \\
\hline Amelanchier arborea var. arborea & Tree & Native & Perennial \\
\hline Amphicarpaea bracteata & Ferns and Forbs & Native & Annual \\
\hline Antennaria neglecta & Ferns and Forbs & Native & Perennial \\
\hline Antennaria plantaginifolia & Ferns and Forbs & Native & Perennial \\
\hline Antennaria virginica & Ferns and Forbs & Native & Perennial \\
\hline Asclepias quadrifolia & Ferns and Forbs & Native & Perennial \\
\hline Asplenium platyneuron & Ferns and Forbs & Native & Perennial \\
\hline Aster spp. & Ferns and Forbs & Native? & Perennial \\
\hline Aureolaria laevigata & Ferns and Forbs & Native & Perennial \\
\hline Aureolaria virginica & Ferns and Forbs & Native & Perennial \\
\hline Bromus cf. latiglumis & Graminoid & Native & Perennial \\
\hline Bromus latiglumis & Graminoid & Native & Perennial \\
\hline Carex cephalophora & Graminoid & Native & Perennial \\
\hline Carex cf. pensylvanica & Graminoid & Native & Perennial \\
\hline Carex cf. pensylvanica/lucorum & Graminoid & Native & Perennial \\
\hline Carex cf. pensylvanica/lucorum/tonsa & Graminoid & Native & Perennial \\
\hline Carex digitalis & Graminoid & Native & Perennial \\
\hline Carex laxiflora & Graminoid & Native & Perennial \\
\hline Carex pensylvanica & Graminoid & Native & Perennial \\
\hline Carex spp. & Graminoid & Native & Perennial \\
\hline Carex willdenowii & Graminoid & Native & Perennial \\
\hline Carya glabra & Tree & Native & Perennial \\
\hline Carya ovata & Tree & Native & Perennial \\
\hline Carya spp. & Tree & Native & Perennial \\
\hline Cf. Bromus ciliatus/Calamagrostis porteri & Graminoid & Native & Perennial \\
\hline Cf. Bromus pubescens & Graminoid & Native & Perennial \\
\hline Cf. Saxifraga caroliniana & Ferns and Forbs & Native & Perennial \\
\hline Cf. Bromus spp. & $\begin{array}{l}\text { Graminoid } \\
\text { Shrubs and }\end{array}$ & Native & Perennial \\
\hline Cf. Ceanothus americanus & Vines & Native & Perennial \\
\hline Cf. Cerastium arvense & Ferns and Forbs & Native Invasive & Perennial \\
\hline Cf. Festuca subverticillata & Graminoid & Native & Perennial \\
\hline Cf. Helianthus sp. & $\begin{array}{c}\text { Ferns and Forbs } \\
\text { Shrubs and }\end{array}$ & Native? & Annual \\
\hline Cf. Lonicera $x$ bella & Vines & Exotic Invasive & Perennial \\
\hline Cf. Muhlenbergia schreberiffrondosa & Graminoid & Native & Perennial \\
\hline Cf. Packera aurea & Ferns and Forbs & Native & Perennial \\
\hline Cf. Packera obovata & Ferns and Forbs & Native & Perennial \\
\hline
\end{tabular}


Cf. Parnassia spp.

Cf. Poa sylvestris

Cf. Solidago arguta/speciosa

Cf. UK Asteraceae

Cf. Verbascum blattaria

Chimaphila maculata

Convolvulus spp.

Corydalis flavula

Cratageous spp.

Cunila origanoides

Danthonia compressa

Danthonia spicata

Deschampsia flexuosa

Dichanthelium boscii

Dichanthelium commutatum

Dichanthelium depauperatum

Dichanthelium latifolium

Dichanthelium linearifolium

Dichanthelium spp.

Dioscorea villosa

Draba ramosissima

Dryopteris marginalis

Elymus histrix

Epigaea repens

Erechtites hieracifolia

Festuca subverticillata

Galium circaezans var. circaezans

Galium lanceolatum

Galium triflorum

Gaultheria procumbens

Gaylussacia baccata

Hamamelis virginiana

Hedeoma pulegioides

Helianthus sp.

Hepatica nobilis

Heuchera americana

Hieracium pilosella var. pilosella

Hieracium venosum

Houstonia cf. caerulea

Houstonia longifolia

Juncus tenuis

Kalmia latifolia

Lespedeza hirta ssp. hirta

Lespedeza procumbens

Lolium arundinaceum

\begin{tabular}{|c|c|c|}
\hline Ferns and Forbs & Native & Perennial \\
\hline Graminoid & Native & Perennial \\
\hline Ferns and Forbs & Native & Perennial \\
\hline Ferns and Forbs & Native? & Perennial \\
\hline $\begin{array}{c}\text { Ferns and Forbs } \\
\text { Shrubs and }\end{array}$ & Exotic & Biennial \\
\hline Vines & Native & Perennial \\
\hline Ferns and Forbs & Native & Perennial \\
\hline $\begin{array}{c}\text { Ferns and Forbs } \\
\text { Shrubs and }\end{array}$ & Native & Annual \\
\hline Vines & Native & Perennial \\
\hline Ferns and Forbs & Native & Perennial \\
\hline Graminoid & Native & Perennial \\
\hline Graminoid & Native & Perennial \\
\hline Graminoid & Native & Perennial \\
\hline Graminoid & Native & Perennial \\
\hline Graminoid & Native & Perennial \\
\hline Graminoid & Native & Perennial \\
\hline Graminoid & Native & Perennial \\
\hline Graminoid & Native & Perennial \\
\hline Graminoid & Native & Perennial \\
\hline Ferns and Forbs & Native & Perennial \\
\hline Ferns and Forbs & Native & Perennial \\
\hline Ferns and Forbs & Native & Perennial \\
\hline $\begin{array}{l}\text { Graminoid } \\
\text { Shrubs and }\end{array}$ & Native & Perennial \\
\hline $\begin{array}{l}\text { Shrubs and } \\
\text { Vines }\end{array}$ & Native & Perennial \\
\hline Ferns and Forbs & Native Weed & Annual \\
\hline Graminoid & Native & Perennial \\
\hline Ferns and Forbs & Native & Perennial \\
\hline Ferns and Forbs & Native & Perennial \\
\hline Ferns and Forbs & Native & Perennial \\
\hline Vines & Native & Perennial \\
\hline Shrubs and & & \\
\hline Vines & Native & Perennial \\
\hline Shrubs and & & \\
\hline Vines & Native & Perennial \\
\hline Ferns and Forbs & Native Weed & Annual \\
\hline Ferns and Forbs & Native & Annual \\
\hline Ferns and Forbs & Native & Perennial \\
\hline Ferns and Forbs & Native & Perennial \\
\hline Ferns and Forbs & Exotic & Perennial \\
\hline Ferns and Forbs & Native & Perennial \\
\hline Ferns and Forbs & Native & Perennial \\
\hline Ferns and Forbs & Native & Perennial \\
\hline Graminoid & Native & Perennial \\
\hline Shrubs and & & \\
\hline Vines & Native & Perennial \\
\hline Ferns and Forbs & Native & Perennial \\
\hline Ferns and Forbs & Native & Perennial \\
\hline Graminoid & Exotic & Perennial \\
\hline
\end{tabular}


Maianthemum racemosum ssp. racemosum

Nyssa sylvatica

Ostrya virginiana

Parietaria pensylvanica

Paronychia canadensis

Parthenocissus quinquefolia

Phlox subulata

Pinus pungens

Pinus rigida

Pinus spp.

Pinus strobus

Pinus virginiana

Pinus virginiana/pungens

Poa cf. trivialis

Poa compressa

Polygonatum biflorum

Polygonum cf. convolvulus

Polygonum scandens

Polypodium vulgare

Potentilla simplex

Prenanthes alba

Prunus serotina

Pseudognaphalium obtusifolium ssp. obtusifolium

Pteridium aquilinum

Quercus coccinea

Quercus ilicifolia

Quercus prinus

Quercus rubra

Quercus spp.

Quercus velutina

Rhus aromatica

Robinia pseudoacacia

Rosa carolina

Rubus spp.

Sassifrass albidum

Sedum ternatum/glaucophyllum

Smilax rotundifolia

Solidago cf.. curtisii

Solidago sp.

Sphenopholis nitida

Spiraea betulifolia var. corymbosa

Symphyotrichum cf. divaricatum

Ferns and Forbs
Tree
Tree
Ferns and Forbs
Ferns and Forbs
Shrubs and
Vines
Shrubs and
Vines
Tree
Tree
Tree
Tree
Tree
Tree
Graminoid
Graminoid
Ferns and Forbs
Shrubs and
Vines
Shrubs and
Vines

Ferns and Forbs

Ferns and Forbs

Ferns and Forbs

Tree

Ferns and Forbs

Ferns and Forbs

Tree

Shrubs and

Vines

Tree

Tree

Tree

Tree

Shrubs and

Vines

Tree

Shrubs and

Vines

Shrubs and

Vines

Tree

Ferns and Forbs

Shrubs and

Vines

Ferns and Forbs

Ferns and Forbs

Graminoid

Shrubs and

Vines

Ferns and Forbs
Native

Native

Native

Native

Native

Perennial

Perennial

Perennial

Annual

Annual

Native

Perennial

Native

Perennial

Native

Perennial

Native

Perennial

Native

Perennial

Native

Perennial

Native

Perennial

Native

Perennial

Exotic

Perennial

Exotic Invasive

Perennial

Native

Perennial

Exotic

Annual

Native Invasive

Perennial

Native

Perennial

Native

Perennial

Native

Biennial

Native

Perennial

Native

Annual

Native Invasive Perennial

Native

Perennial

Native

Perennial

Native

Perennial

Native

Perennial

Native

Perennial

Native

Perennial

Native

Perennial

Native Invasive Perennial

Native Perennial

Native Weed

Perennial

Native

Perennial

Native

Perennial

Native

Perennial

Native

Perennial

Native

Perennial

Native

Perennial

Native

Perennial

Native

Annual 
Symphyotrichum divaricatum

Thalictrum thalictroides

Triodanis perfoliata

UK Asteraceae

UK Dicot

UK Fern

UK Poaceae

Uvularia perfoliata

Uvularia puberula

Uvularia sessilifolia

Vaccinium pallidum

Vaccinium stamineum

Verbascum $s p$.

Viburnum acerifolium

Viburnum prunifolium

Vicia caroliniana

Viola cf. palmata

Viola cf. sororia

Viola palmata

Viola pedata

Vitis aestivalis var. bicolor

Vitis $s p$.

$\begin{array}{ccc}\text { Ferns and Forbs } & \text { Native } & \text { Annual } \\ \text { Ferns and Forbs } & \text { Native } & \text { Perennial } \\ \text { Ferns and Forbs } & \text { Native } & \text { Annual } \\ \text { Ferns and Forbs } & \text { Native? } & \text { Perennial } \\ \text { Ferns and } & & \\ \text { Forbs? } & \text { Native? } & \text { Perennial? } \\ \text { Ferns and Forbs } & \text { Native } & \text { Perennial } \\ \text { Graminoid } & \text { Native? } & \text { Perennial } \\ \text { Ferns and Forbs } & \text { Native } & \text { Perennial } \\ \text { Ferns and Forbs } & \text { Native } & \text { Perennial } \\ \text { Ferns and Forbs } & \text { Native } & \text { Perennial } \\ \text { Shrubs and } & & \\ \text { Vines } & \text { Native } & \text { Perennial } \\ \text { Shrubs and } & & \\ \text { Vines } & \text { Native } & \text { Perennial } \\ \text { Ferns and Forbs } & \text { Native? } & \text { Perennial? } \\ \text { Shrubs and } & & \\ \text { Vines } & \text { Native } & \text { Perennial } \\ \text { Tree } & \text { Native } & \text { Perennial } \\ \text { Shrubs and } & & \\ \text { Vines } & \text { Native } & \text { Perennial } \\ \text { Ferns and Forbs } & \text { Native } & \text { Perennial } \\ \text { Ferns and Forbs } & \text { Native } & \text { Annual } \\ \text { Ferns and Forbs } & \text { Native } & \text { Perennial } \\ \text { Ferns and Forbs } & \text { Native } & \text { Perennial } \\ \text { Shrubs and } & & \\ \text { Vines } & \text { Native Invasive } & \text { Perennial } \\ \text { Shrubs and } & & \\ \text { Vines } & \text { Native Invasive } & \text { Perennial } \\ & & \end{array}$


Table 2. Post-fire (2007) understory layer vascular plants encountered on $1 \mathrm{~m}^{2}$ plots $(\mathrm{n}=$ 144). UK = unknown.

\begin{tabular}{|c|c|c|c|}
\hline & & Functional & \\
\hline Species & Habit & Type & Duration \\
\hline Acer pensylvanicum & Tree & Native Weed & Perennial \\
\hline Acer rubrum & Tree & Native Weed & Perennial \\
\hline Ageratina altissima var. altissima & Ferns and Forbs & Native Weed & Perennial \\
\hline Ailanthus altissima & Tree & Exotic Invasive & Perennial \\
\hline Alliaria petiolata & Ferns and Forbs & Exotic Invasive & Annual \\
\hline Allium cernuum & Ferns and Forbs & Native & Perennial \\
\hline Ambrosia artemisiifolia & Ferns and Forbs & Native Weed & Annual \\
\hline Amelanchier arborea & Tree & Native & Perennial \\
\hline Amphicarpaea bracteata & Ferns and Forbs & Native & Annual \\
\hline Antennaria neglecta & Ferns and Forbs & Native & Perennial \\
\hline Antennaria plantaginifolia & Ferns and Forbs & Native & Perennial \\
\hline Antennaria virginica & Ferns and Forbs & Native & Perennial \\
\hline Asclepias quadrifolia & Ferns and Forbs & Native & Perennial \\
\hline Asplenium platyneuron & Ferns and Forbs & Native & Perennial \\
\hline Aureolaria flava var. flava & Ferns and Forbs & Native & Perennial \\
\hline Botrychium virginianum & Ferns and Forbs & Native & Perennial \\
\hline Brachyletrum erectum & Graminoid & Native & Perennial \\
\hline Campanula divaricata & Ferns and Forbs & Native & Perennial \\
\hline Carex cephalophora & Graminoid & Native & Perennial \\
\hline Carex cf. pensylvanica & Graminoid & Native & Perennial \\
\hline Carex cf. pensylvanica/lucorum & Graminoid & Native & Perennial \\
\hline Carex cf. pensylvanica/lucorum/tonsa & Graminoid & Native & Perennial \\
\hline Carex cf. tonsa & Graminoid & Native & Perennial \\
\hline Carex digitalis & Graminoid & Native & Perennial \\
\hline Carex laxiflora & Graminoid & Native & Perennial \\
\hline Carex pensylvanica & Graminoid & Native & Perennial \\
\hline Carex spp. & Graminoid & Native & Perennial \\
\hline Carya glabra & $\begin{array}{c}\text { Tree } \\
\text { Shrubs and }\end{array}$ & Native & Perennia \\
\hline Ceanothus americanus & Vines & Native & Perennial \\
\hline Cf. Aster spp. & Ferns and Forbs & Native? & Perennial \\
\hline Cf. Aureolaria laevigata & Ferns and Forbs & Native & Perennial \\
\hline Cf. Bromus ciliatus/Calamagrostis porteri & Graminoid & Native & Perennial \\
\hline Cf. Festuca subverticillata & Graminoid & Native & Perennial \\
\hline Cf. Hieracium spp. & Ferns and Forbs & Native? & Perennial \\
\hline Cf. Ilex montana & Tree & Native & Perennial \\
\hline Cf. Lysimachia quadrifolia & Ferns and Forbs & Native & Perennial \\
\hline Cf. Phlox buckleyi & Ferns and Forbs & Native & Perennial \\
\hline Cf. Sassafras albidum & Tree & Native & Perennial \\
\hline Cf. Scrophularia lanceolata & Ferns and Forbs & Native & Perennial \\
\hline Cf. Sericocarpus asteroides & Ferns and Forbs & Native & Perennial \\
\hline Cf. UK Asteraceae & $\begin{array}{c}\text { Ferns and Forbs } \\
\text { Shrubs and }\end{array}$ & Native? & Perennial \\
\hline Chimaphila maculata & Vines & Native & Perennial \\
\hline Comandra cf. umbellata & Ferns and Forbs & Native & Perennial \\
\hline
\end{tabular}


Corydalis flavula

Corylus americana

Cratageous spp.

Cunila origanoides

Danthonia spicata

Danthonia spp.

Dennstaedtia punctilobula

Deschampsia flexuosa

Dichanthelium boscii

Dichanthelium commutatum

Dichanthelium depauperatum

Dichanthelium latifolium

Dioscorea villosa

Draba ramosissima

Dryopteris marginalis

Erechtites hieraciifolia

Festuca subverticillata

Fraxinus americana

Galium circaezans var. circaezans

Galium lanceolatum

Galium triflorum

Gaylussacia baccata

Goodyera spp.

GRubus spp.

Hamamelis virginiana

Hedeoma pulegioides

Helianthus cf. divaricatus

Helianthus divaricatus

Hepatica nobilis var. obtusa

Heuchera americana

Hieracium pilosella var. pilosella

Hieracium venosum

Houstonia longifolia

Iris verna

Kalmia latifolia

Lespedeza cf. violacea

Lespedeza hirta ssp. hirta

Lespedeza repens

Maianthemum racemosum ssp. racemosum

Melampyrum lineare

Mentha suaveolens

Muhlenbergia tenuiflora

Nyssa Sylvatica

Ostrya virginiana

Oxalis cf. stricta

Parietaria pensylvanica
Ferns and Forbs

Shrubs and Vines

Shrubs and Vines

Ferns and Forbs

Graminoid

Graminoid

Ferns and Forbs

Graminoid

Graminoid

Graminoid

Graminoid

Graminoid

Ferns and Forbs

Ferns and Forbs

Ferns and Forbs

Ferns and Forbs

Graminoid

Tree

Ferns and Forbs

Ferns and Forbs

Ferns and Forbs

Shrubs and Vines

Ferns and Forbs

Shrubs and Vines

Shrubs and Vines

Ferns and Forbs

Ferns and Forbs

Ferns and Forbs

Ferns and Forbs

Ferns and Forbs

Ferns and Forbs

Ferns and Forbs

Ferns and Forbs

Ferns and Forbs

Shrubs and Vines

Ferns and Forbs

Ferns and Forbs

Ferns and Forbs

Ferns and Forbs

Ferns and Forbs

Ferns and Forbs

Graminoid

Tree

Tree

Ferns and Forbs

Ferns and Forbs
Native

Annual

Native

Perennial

Native

Perennial

Native

Native

Native

Perennial

Perennial

Perennial

Native Invasive Perennial

Native

Perennial

Native Perennial

Native Perennial

Native Perennial

Native Perennial

Native Perennial

Native Perennial

Native Perennial

Native Weed Annual

Native Perennial

Native Perennial

Native Perennial

Native Perennial

Native Perennial

Native Perennial

Native Perennial

Native Perennial

Native Perennial

Native Weed Annual

Native Perennial

Native Perennial

Native Perennial

Native Perennial

Exotic Perennial

Native Perennial

Native Perennial

Native Perennial

Native Perennial

Native Perennial

Native Perennial

Native Perennial

Native Perennial

Native Annual

Exotic Perennial

Native Perennial

Native Perennial

Native Perennial

Native Perennial

Native Annual 
Paronychia canadensis

Paronychia fastigiata/montana

Parthenocissus quinquefolia

Phytolacca americana var. americana

Pinus rigida

Pinus strobus

Pinus virginiana

Poa compressa

Polygala senega

Polygonatum biflorum

Polygonum cf. convolvulus

Potentilla simplex

Prenanthes alba

Prunus serotina

Pteridium aquilinum

Quercus ilicifolia

Quercus prinus

Quercus rubra

Quercus velutina

Robinia pseudoacacia

Rosa carolina

Rubus spp.

Rumex cf. obtusifolius

Sassafras albidum

Saxifraga caroliniana

Sedum ternatum/glaucophyllum

Smilax rotundifolia

Solidago caesia

Solidago cf. curtisii

Solidago cf. nemoralis

Spiraea betulifolia var. corymbosa

Symphyotrichum divaricatum

Taenidia integerrima

Tephrosia virginiana

Thalictrum thalictroides

Toxicodendron radicans

Triodanis perfoliata var. perfoliata

UK Asteraceae

UK Dicot

Uvularia perfoliata

Uvularia puberula

Vaccinium pallidum
Ferns and Forbs

Ferns and Forbs

Shrubs and Vines

Ferns and Forbs Tree

Tree

Tree

Graminoid

Ferns and Forbs

Ferns and Forbs

Shrubs and

Vines

Ferns and Forbs

Ferns and Forbs

Tree

Ferns and Forbs

Shrubs and

Vines

Tree

Tree

Tree

Tree

Shrubs and

Vines

Shrubs and

Vines

Ferns and Forbs Tree

Ferns and Forbs

Ferns and Forbs

Shrubs and

Vines

Ferns and Forbs

Ferns and Forbs

Ferns and Forbs

Shrubs and

Vines

Ferns and Forbs

Ferns and Forbs

Ferns and Forbs

Ferns and Forbs

Shrubs and

Vines

Ferns and Forbs

Ferns and Forbs

Ferns and

Forbs?

Ferns and Forbs

Ferns and Forbs

Shrubs and

Vines
Native

Native

Annual

Annual

Native Perennial

Native Weed Perennial

Native Perennial

Native Perennial

Native Perennial

Exotic Invasive Perennial

Native Perennial

Native Perennial

Exotic

Native

Native

Annual

Perennial

Biennial

Native

Perennial

Native Invasive Perennial

Native

Perennial

Native

Perennial

Native

Perennial

Native

Perennial

Native Invasive Perennial

Native

Perennial

Native Weed Perennial

Exotic Perennial

Native Perennial

Native Perennial

Native Perennial

Native Perennial

Native Perennial

Native Perennial

Native Perennial

Native Perennial

Native Annual

Native Perennial

Native Perennial

Native Perennial

Native Invasive Perennial

Native Annual

Native? Perennial

Native? Perennial?

Native Perennial

Native Perennial

Native Perennial 
Vaccinium stamineum

Veronica officinalis

Viburnum acerifolium

Vicia caroliniana

Viola cf. palmata

Viola palmata

Vitis aestivalis var. bicolor

Vitis vulpina
Shrubs and Vines

Ferns and Forbs Shrubs and Vines

Shrubs and Vines

Ferns and Forbs

Ferns and Forbs Shrubs and Vines Shrubs and Vines
Native Perennial

Exotic Perennial

Native Perennial

Native Perennial

Native Perennial

Native Perennial

Native Invasive Perennial

Native Invasive Perennial 
Table 3. Post-fire (2007) understory layer vascular plants encountered during the timed meander inventory $(n=36)$. UK = unknown.

\begin{tabular}{|c|c|c|c|}
\hline & W & Functional & \\
\hline Acer pensylvanicum & Tree & $\frac{\text { Cype }}{\text { Native Weed }}$ & Perennial \\
\hline Acer rubrum var. rubrum & Tree & Native Weed & Perennial \\
\hline Acer saccharum var. saccharum & Tree & Native & Annual \\
\hline Actaea racemosa var. racemosa & Ferns and Forbs & Native & Perennial \\
\hline Adiantum pedatum & Ferns and Forbs & Native & Biennial \\
\hline Ageratina altissima var. altissima & Ferns and Forbs & Native Weed & Perennial \\
\hline Ailanthus altissima & Tree & Exotic Invasive & Perennial \\
\hline Alliaria petiolata & Ferns and Forbs & Exotic Invasive & Perennial \\
\hline Allium cernuum & Ferns and Forbs & Native & Perennial \\
\hline Allium cf. cernuum & Ferns and Forbs & Native? & Perennial \\
\hline Ambrosia artemisiifolia & Ferns and Forbs & Native Weed & Perennial \\
\hline Amelanchier arborea var. arborea & Tree & Native & Perennial \\
\hline Amphicarpaea bracteata & Ferns and Forbs & Native & Perennial \\
\hline Anaphalis margaritacea & Ferns and Forbs & Native Weed & Perennial \\
\hline Antennaria neglecta & Ferns and Forbs & Native & Perennial \\
\hline Antennaria plantaginifolia & Ferns and Forbs & Native & Perennial \\
\hline Antennaria virginica & Ferns and Forbs & Native & Perennial \\
\hline Apocynum spp. & Ferns and Forbs & Native Weed & Perennial \\
\hline Arabis canadensis & Ferns and Forbs & Native & Perennial \\
\hline Aralia spinosa & Tree & Native Weed & Perennial \\
\hline Aristolochia serpentaria & Ferns and Forbs & Native & Perennial \\
\hline Asclepias quadrifolia & Ferns and Forbs & Native & Perennial \\
\hline Asplenium platyneuron & Ferns and Forbs & Native & Perennial \\
\hline Aster spp. & Ferns and Forbs & Native? & Perennial \\
\hline Aureolaria flava var. flava & Ferns and Forbs & Native & Perennial \\
\hline Aureolaria laevigata & Ferns and Forbs & Native & Biennial \\
\hline Botrychium virginianum & Ferns and Forbs & Native & Perennial \\
\hline Brachyletrum erectum & Graminoid & Native & Perennial \\
\hline Campanula divaricata & Ferns and Forbs & Native & Perennial \\
\hline Carex cephalophora & Graminoid & Native & Perennial \\
\hline Carex cf. pensylvanica & Graminoid & Native & Perennial \\
\hline Carex cf. pensylvanica/lucorum & Graminoid & Native & Perennial \\
\hline Carex cf. pensylvanica/lucorum/tonsa & Graminoid & Native & Perennial \\
\hline Carex cf. tonsa & Graminoid & Native & Perennial \\
\hline Carex digitalis & Graminoid & Native & Perennial \\
\hline Carex laxiflora & Graminoid & Native & Perennial \\
\hline Carex pensylvanica & Graminoid & Native & Perennial \\
\hline Carex spp. & Graminoid & Native & Annual \\
\hline Carex spp. 1 & Graminoid & Native & Perennial \\
\hline Carya alba & Tree & Native & Perennial \\
\hline Carya glabra & Tree & Native & Annual \\
\hline Carya ovata & Tree & Native & Perennial \\
\hline Castanea dentata & Tree & Native & Perennial \\
\hline Caulophyllum thalictroides & Ferns and Forbs & Native & Perennial \\
\hline Ceanothus americanus & Shrubs and & Native & Perennial \\
\hline
\end{tabular}


Cercis canadensis var. canadensis

Cf. Agrostis perennans

Cf. Aster spp.

$C f$. Aureolaria laevigata

Cf. Bromus ciliatus/Calamagrostis porteri

Cf. Bromus pubescens

Cf. Calystegia spithamaea ssp. purshiana

Cf. Doellingeria infirma

Cf. Euthamia spp.

Cf. Festuca subverticillata

Cf. Hackelia virginiana

Cf. Heuchera americana

Cf. Hieracium spp.

Cf. Ilex montana

Cf. Ionactis linariifolius

Cf. Lactuca spp.

Cf. Lathyrus venosus

Cf. Lindera benzoin

Cf. Lyonia mariana

Cf. Lysimachia quadrifolia

Cf. Menziesia pilosa

Cf. Phlox buckleyi

Cf. Phytolacca americana var. americana

Cf. Prenanthes spp.

Cf. Pycnanthemum spp.

Cf. Sassafras albidum

Cf. Scrophularia lanceolata

Cf. Sericocarpus asteroides

Cf. Sericocarpus linifolius

Cf. Solidago bicolor

Cf. Solidago curtisii

Cf. Thaspium barbinode

Cf. Thaspium/Zizia spp.

Cf. UK Asteraceae

Chimaphila maculata

Cirsium palustre

Cirsium vulgare

Comandra cf. umbellata

Conopholis americana

Cornus florida

Corydalis flavula

Corylus americana

Cratageous spp.

Cunila origanoides

\begin{tabular}{|c|c|c|}
\hline \multicolumn{3}{|l|}{ Vines } \\
\hline \multicolumn{3}{|l|}{ Vines } \\
\hline Graminoid & Native? & Perennial \\
\hline Ferns and Forbs & Native? & Perennial \\
\hline Ferns and Forbs & Native & Perennial \\
\hline Graminoid & Native & Perennial \\
\hline Graminoid & Native & Perennial? \\
\hline Ferns and Forbs & Native & Perennial \\
\hline Ferns and Forbs & Native & Perennial \\
\hline Ferns and Forbs & Native Weed & Perennial \\
\hline Graminoid & Native & Perennial \\
\hline Ferns and Forbs & Native & Perennial \\
\hline Ferns and Forbs & Native & Perennial \\
\hline Ferns and Forbs & Native? & Perennial \\
\hline Tree & Native & Perennial \\
\hline Ferns and Forbs & Native & Perennial \\
\hline $\begin{array}{l}\text { Ferns and Forbs } \\
\text { Shrubs and }\end{array}$ & Native? & Perennial \\
\hline Vines & Native & Perennial \\
\hline Shrubs and & & \\
\hline Vines & Native & Perennial \\
\hline Shrubs and & & \\
\hline Vines & Native & Perennial \\
\hline Ferns and Forbs & Native & Perennial \\
\hline Shrubs and & & \\
\hline Vines & Native & Perennial \\
\hline Ferns and Forbs & Native & Perennial \\
\hline Ferns and Forbs & Native Weed & Perennial \\
\hline Ferns and Forbs & Native & Perennial \\
\hline Ferns and Forbs & Native & Perennial \\
\hline Tree & Native & Perennial \\
\hline Ferns and Forbs & Native & Perennial \\
\hline Ferns and Forbs & Native & Perennial \\
\hline Ferns and Forbs & Native & Perennial \\
\hline Ferns and Forbs & Native & Annual \\
\hline Ferns and Forbs & Native & Perennial \\
\hline Ferns and Forbs & Native & Perennial \\
\hline Ferns and Forbs & Native & Perennial \\
\hline Ferns and Forbs & Native? & Perennial \\
\hline Shrubs and & & \\
\hline Vines & Native & Perennial \\
\hline Ferns and Forbs & Exotic & Perennial \\
\hline Ferns and Forbs & Exotic & Biennial \\
\hline Ferns and Forbs & Native & Perennial \\
\hline Ferns and Forbs & Native & Perennial \\
\hline Tree & Native & Perennial \\
\hline Ferns and Forbs & Native & Perennial \\
\hline Shrubs and & & \\
\hline Vines & Native & Perennial \\
\hline Shrubs and & & \\
\hline Vines & Native & Perennial \\
\hline Ferns and Forbs & Native & Perennial \\
\hline
\end{tabular}


Cynoglossum virginianum

Danthonia cf. spicata

Danthonia spicata

Danthonia spp.

Daucus carota

Dennstaedtia punctilobula

Deschampsia flexuosa

Desmodium nudiflorum

Desmodium rotundifolium

Desmodium spp.

Dichanthelium boscii

Dichanthelium clandestinum

Dichanthelium commutatum

Dichanthelium depauperatum

Dichanthelium latifolium

Dioscorea villosa

Doellingeria infirma

Draba ramosissima

Dryopteris marginalis

Elaeagnus umbellata var. parviflora Elymus hystrix var. hystrix

Epigaea repens

Erechtites hieraciifolia

Erigeron strigosus

Festuca subverticillata

Fraxinus americana

Galium circaezans var. circaezans

Galium lanceolatum

Galium triflorum

Gaultheria procumbens

Gaylussacia baccata

Goodyera spp.

GRubus spp.

Hamamelis virginiana

Hedeoma pulegioides

Helianthus cf. divaricatus

Helianthus divaricatus

Helianthus spp.

Hepatica nobilis var. obtusa

Heuchera americana

Hieracium caespitosum

Hieracium pilosella var. pilosella

Hieracium venosum

Houstonia longifolia

Iris verna

Juniperus virginiana var. virginiana
Ferns and Forbs

Graminoid

Graminoid

Graminoid

Ferns and Forbs

Ferns and Forbs Graminoid

Ferns and Forbs

Ferns and Forbs

Ferns and Forbs

Graminoid

Graminoid

Graminoid

Graminoid

Graminoid

Ferns and Forbs

Ferns and Forbs

Ferns and Forbs

Ferns and Forbs

Shrubs and

Vines

Graminoid

Shrubs and

Vines

Ferns and Forbs

Ferns and Forbs

Graminoid

Tree

Ferns and Forbs

Ferns and Forbs

Ferns and Forbs

Shrubs and

Vines

Shrubs and

Vines

Ferns and Forbs

Shrubs and

Vines

Shrubs and

Vines

Ferns and Forbs

Ferns and Forbs

Ferns and Forbs

Ferns and Forbs

Ferns and Forbs

Ferns and Forbs

Ferns and Forbs

Ferns and Forbs

Ferns and Forbs

Ferns and Forbs

Ferns and Forbs

Tree

Native Weed
Native
Native
Native
Exotic

Native Invasive

Native

Native

Native

Native

Native

Native Weed

Native

Native

Native

Native

Native

Native

Native

Exotic Invasive

Native

Native

Native Weed

Native Weed

Native

Native

Native

Native

Native

Native

Native

Native

Native

Native

Native Weed

Native

Native

Native

Native

Native

Exotic

Exotic

Native

Native

Native

Native Weed
Perennial

Perennial

Annual

Annual

Biennial

Perennial

Annual

Perennial

Perennial

Perennial

Perennial

Perennial

Perennial?

Perennial?

Annual

Perennial

Perennial

Perennial

Perennial

Annual

Perennial

Perennial

Perennial

Perennial

Perennial

Perennial

Annual

Perennial

Perennial

Perennial

Perennial

Perennial

Perennial

Perennial

Perennial

Perennial

Perennial

Perennial

Perennial

Perennial

Perennial

Perennial

Perennial

Perennial

Perennial

Perennial 
Kalmia latifolia

Laportea canadensis

Lespedeza cf. violacea

Lespedeza hirta ssp. hirta

Lespedeza procumbens

Lespedeza repens

Lespedeza violacea

Lindera benzoin

Lobelia spp.

Maianthemum racemosum ssp. racemosum

Melampyrum lineare

Mentha suaveolens

Menziesia pilosa

Microstegium vimineum

Monotropa uniflora

Muhlenbergia tenuiflora

Nyssa sylvatica

Ostrya virginiana var. virginiana

Oxalis cf. stricta

Parietaria pensylvanica

Paronychia canadensis

Paronychia fastigiata/montana

Parthenocissus quinquefolia

Penstemon canescens

Penstemon cf. canescens

Phlox subulata

Phytolacca americana var. americana

Pilea pumila

Pinus pungens

Pinus rigida

Pinus strobus

Pinus virginiana

Pinus virginiana/pungens

Poa compressa

Polygala senega

Polygonatum biflorum

Polygonum cf. convolvulus

Polystichum acrostichoides

Potentilla simplex

Prenanthes alba

Prenanthes serpentaria

Prenanthes spp.

Prunella vulgaris

Prunus americana

Prunus pensylvanica var. pensylvanica

Prunus serotina

\section{Shrubs and \\ Vines \\ Ferns and Forbs \\ Ferns and Forbs \\ Ferns and Forbs \\ Ferns and Forbs \\ Ferns and Forbs \\ Ferns and Forbs \\ Shrubs and \\ Vines}

Ferns and Forbs

Ferns and Forbs

Ferns and Forbs

Ferns and Forbs

Shrubs and

Vines

Graminoid

Ferns and Forbs

Graminoid

Tree

Tree

Ferns and Forbs

Ferns and Forbs

Ferns and Forbs

Ferns and Forbs

Shrubs and

Vines

Ferns and Forbs

Ferns and Forbs

Shrubs and

Vines

Ferns and Forbs

Ferns and Forbs

Tree

Tree

Tree

Tree

Tree

Graminoid

Ferns and Forbs

Ferns and Forbs

Shrubs and

Vines

Ferns and Forbs

Ferns and Forbs

Ferns and Forbs

Ferns and Forbs

Ferns and Forbs

Ferns and Forbs

Tree

Tree

Tree
Native

Perennial

Native Perennial

Native

Native

Native

Native

Native

Native

Native?

Native

Native

Exotic

Native

Exotic Invasive

Native

Native

Native

Native

Native

Native

Native

Native

Native

Native

Native

Native

Native Weed

Native

Native

Native

Native

Native

Native

Exotic Invasive

Native

Native

Exotic

Native

Native

Native

Native

Native

Native

Native

Native

Native
Annual

Perennial

Perennial

Annual

Annual

Perennial

Perennial

Annual

Perennial

Perennial

Perennial

Perennial

Perennial

Perennial

Perennial

Perennial

Annual

Perennial

Perennial

Perennial

Perennial

Perennial

Biennial

Perennial

Perennial

Perennial

Perennial

Perennial

Perennial

Perennial

Perennial

Perennial

Perennial

Perennial

Perennial

Perennial

Perennial

Perennial

Perennial

Perennial

Perennial

Perennial

Perennial

Perennial 
Pteridium aquilinum

Pycnanthemum incanum

Quercus alba

Quercus coccinea var. coccinea

Quercus ilicifolia

Quercus marilandica var. marilandica

Quercus prinus

Quercus rubra

Quercus velutina

Rhus glabra

Rhus typhina

Robinia pseudoacacia

Rosa carolina var. carolina

Rubus occidentalis

Rubus spp.

Rumex acetosella

Rumex cf. obtusifolius

Sassafras albidum

Saxifraga caroliniana

Scutellaria ovata

Sedum ternatum/glaucophyllum

Silene stellata

Smilax glauca

Smilax rotundifolia

Solidago bicolor

Solidago caesia

Solidago cf. curtisii

Solidago cf. nemoralis

Spiraea betulifolia var. corymbosa

Symphyotrichum cf. cordifolium/Eurybia cf. schreberi

Symphyotrichum of. divaricatum

Symphyotrichum divaricatum

Symphyotrichum praealtum

Symphyotrichum undulatum

Taenidia integerrima

Tephrosia virginiana

Thalictrum thalictroides

Thelypteris noveboracensis

Toxicodendron radicans

Triodanis perfoliata var. perfoliata

UK Asteraceae

UK Asteraceael

UK Asteraceae2
Ferns and Forbs

Ferns and Forbs

Tree

Tree

Shrubs and

Vines

Shrubs and

Vines

Tree

Tree

Tree

Tree

Tree

Tree

Shrubs and

Vines

Shrubs and

Vines

Shrubs and

Vines

Ferns and Forbs

Ferns and Forbs

Tree

Ferns and Forbs

Ferns and Forbs

Ferns and Forbs

Ferns and Forbs

Shrubs and

Vines

Shrubs and

Vines

Ferns and Forbs

Ferns and Forbs

Ferns and Forbs

Ferns and Forbs

Shrubs and

Vines

Ferns and Forbs

Ferns and Forbs

Ferns and Forbs

Ferns and Forbs

Ferns and Forbs

Ferns and Forbs

Ferns and Forbs

Ferns and Forbs

Ferns and Forbs

Shrubs and

Vines

Ferns and Forbs

Ferns and Forbs

Ferns and Forbs

Ferns and Forbs
Native Invasive Perennial

Native Perennial

Native Perennial

Native Perennial

Native Perennial

Native Perennial

Native Perennial

Native Perennial

Native Perennial

Native Weed Perennial

Native Weed Perennial

Native Invasive Perennial

Native Perennial

Native Weed Perennial

Native Weed Perennial

Exotic Invasive Perennial

Exotic Perennial

Native Perennial

Native Perennial

Native Perennial

Native Perennial

Native Annual

Native Perennial

Native Perennial

Native Annual

Native Perennial

Native Perennial

Native Perennial

Native Perennial

Native Perennial

Native Perennial

Native Perennial

Native Annual

Native Perennial

Native Perennial

Native Perennial

Native Annual

Native Perennial

Native Invasive Perennial

Native Perennial

Native? Perennial

Native? Perennial

Native? Perennial 
UK Asteraceae3

UK Dicot

UK Dicot1

UK Poaceae

Ulmus rubra

Uvularia perfoliata

Uvularia puberula

Vaccinium pallidum

Vaccinium stamineum

Verbascum thapsus

Veronica officinalis

Viburnum acerifolium

Viburnum prunifolium

Vicia caroliniana

Vicia cf. villosa

Viola cf. palmata

Viola cf. sororia

Viola palmata

Viola pedata

Vitis aestivalis var. bicolor

Vitis vulpina

\begin{tabular}{|c|c|c|}
\hline Forbs? & Native? & Perennial \\
\hline \multicolumn{3}{|l|}{ Ferns and } \\
\hline Forbs? & Native? & Perennial \\
\hline Graminoid & Native? & Perennial \\
\hline Tree & Native & Perennial \\
\hline Ferns and Forbs & Native & Perennial \\
\hline Ferns and Forbs & Native & Perennial \\
\hline \multicolumn{3}{|l|}{ Shrubs and } \\
\hline Vines & Native & Perennial \\
\hline \multicolumn{3}{|l|}{ Shrubs and } \\
\hline Vines & Native & Perennial \\
\hline Ferns and Forbs & Exotic & Biennial \\
\hline Ferns and Forbs & Exotic & Perennial \\
\hline \multicolumn{3}{|l|}{ Shrubs and } \\
\hline Vines & Native & Perennial \\
\hline Tree & Native & Perennial \\
\hline \multicolumn{3}{|l|}{ Shrubs and } \\
\hline Vines & Native & Perennial \\
\hline \multicolumn{3}{|l|}{ Shrubs and } \\
\hline Vines & Exotic & Annual \\
\hline Ferns and Forbs & Native & Perennial \\
\hline Ferns and Forbs & Native & Perennial \\
\hline Ferns and Forbs & Native & Perennial \\
\hline Ferns and Forbs & Native & Perennial \\
\hline \multicolumn{3}{|l|}{ Shrubs and } \\
\hline Vines & Native Invasive & Perennial \\
\hline \multicolumn{3}{|l|}{ Shrubs and } \\
\hline Vines & Native Invasive & Perenn \\
\hline
\end{tabular}


Table 4. Pearson correlations for each understory species with axes 2 and 3 of the NMS ordination of combined pre- and post-fire abundance data. $\mathrm{UK}=$ unknown. Exotic invasives are shown in bold.

\begin{tabular}{lcc} 
& $\mathrm{R}^{2}=0.184$ & $\mathrm{R}^{2}=0.178$ \\
Species & Axis $\mathbf{2}$ & Axis $\mathbf{3}$ \\
\hline Acer pensylvanicum & 0.535 & 0.39 \\
Acer rubrum var. rubrum & 0.153 & -0.028 \\
Ageratina altissima var. altissima & 0.627 & -0.048 \\
Alliaria petiolata & $\mathbf{0 . 4 4 6}$ & $\mathbf{0 . 1 3 6}$ \\
Amelanchier arborea var. arborea & -0.006 & -0.093 \\
Amphicarpaea bracteata & 0.311 & -0.059 \\
Antennaria neglecta & -0.092 & -0.409 \\
Antennaria plantaginifolia & 0.028 & -0.073 \\
Antennaria virginica & 0.067 & -0.092 \\
Asplenium platyneuron & 0.442 & -0.122 \\
Carex cephalophora & 0.459 & -0.204 \\
Carex cf. pensylvanica/lucorum & -0.029 & 0.207 \\
Carex cf. pensylvanica/lucorum/tonsa & -0.108 & -0.247 \\
Carex digitalis & 0.091 & 0.068 \\
Carya glabra & 0.235 & -0.352 \\
Carex laxiflora & 0.418 & 0.03 \\
Carya ovata & -0.077 & 0.292 \\
Carex pensylvanica & 0.144 & -0.388 \\
Carex spp. & 0.241 & 0.025 \\
Cf. UK Asteraceae & 0.219 & 0.204 \\
Chimaphila maculata & -0.069 & -0.059 \\
Cratageous spp. & 0.242 & -0.182 \\
Danthonia spicata & -0.218 & -0.378 \\
Deschampsia flexuosa & 0.012 & -0.285 \\
Dennstaedtia punctilobula & 0.365 & -0.025 \\
Dichanthelium boscii & 0.123 & -0.102 \\
Dichanthelium commutatum & 0.112 & 0.301 \\
Dichanthelium depauperatum & 0.095 & -0.364 \\
Dichanthelium latifolium & -0.059 & -0.311 \\
Dioscorea villosa & 0.15 & -0.131 \\
Dryopteris marginalis & -0.016 & -0.009 \\
Erechtites hieraciifolia & 0.382 & 0.109 \\
Festuca subverticillata & 0.214 & 0.246 \\
Galium circaezans var. circaezans & 0.187 & -0.069 \\
Hamamelis virginiana & 0.225 \\
& -0.06 \\
& &
\end{tabular}




\begin{tabular}{|c|c|c|}
\hline Heuchera americana & 0.031 & -0.118 \\
\hline Hepatica nobilis var. obtusa & 0.152 & -0.088 \\
\hline Hedeoma pulegioides & 0.062 & -0.054 \\
\hline Houstonia longifolia & 0.229 & -0.498 \\
\hline Kalmia latifolia & -0.313 & 0.226 \\
\hline Nyssa sylvatica & -0.025 & 0.122 \\
\hline Ostrya virginiana var. virginiana & 0.501 & 0.083 \\
\hline Paronychia canadensis & 0.355 & 0.095 \\
\hline Parietaria pensylvanica & 0.542 & 0.262 \\
\hline Parthenocissus quinquefolia & 0.189 & 0.146 \\
\hline Pinus spp. & -0.033 & 0.201 \\
\hline Pinus strobus & 0.17 & 0.035 \\
\hline Pinus virginiana & -0.255 & -0.335 \\
\hline Polygonatum biflorum & -0.209 & -0.155 \\
\hline Polygonum cf. convolvulus & 0.523 & 0.103 \\
\hline Poa compressa & 0.216 & -0.105 \\
\hline Potentilla simplex & -0.013 & -0.61 \\
\hline Prunus serotina & 0.233 & 0.073 \\
\hline Quercus ilicifolia & -0.456 & -0.056 \\
\hline Quercus prinus & -0.057 & -0.27 \\
\hline Quercus rubra & 0.001 & -0.268 \\
\hline Quercus velutina & -0.153 & -0.224 \\
\hline Rosa carolina var. carolina & -0.202 & -0.167 \\
\hline Robinia pseudoacacia & 0.083 & -0.245 \\
\hline Sassafras albidum & 0.332 & 0.183 \\
\hline Saxifraga caroliniana & 0.454 & -0.115 \\
\hline Sedum ternatum/glaucophyllum & 0.145 & -0.272 \\
\hline Smilax rotundifolia & -0.09 & -0.176 \\
\hline Solidago caesia & 0.276 & -0.217 \\
\hline Symphyotrichum divaricatum & 0.241 & -0.018 \\
\hline Thalictrum thalictroides & 0.286 & -0.083 \\
\hline UK Asteraceae & 0.201 & -0.065 \\
\hline UK Dicot & 0.131 & -0.05 \\
\hline UK Poaceae & -0.049 & 0.238 \\
\hline Uvularia perfoliata & 0.204 & 0.042 \\
\hline Uvularia puberula & -0.063 & 0.027 \\
\hline Vaccinium pallidum & -0.347 & -0.451 \\
\hline Vaccinium stamineum & -0.042 & -0.196 \\
\hline Viburnum acerifolium & -0.216 & 0.079 \\
\hline Vitis aestivalis var. bicolor & 0.208 & 0.007 \\
\hline Vicia caroliniana & 0.375 & -0.068 \\
\hline Viola cf.. palmata & 0.044 & -0.245 \\
\hline Viola palmata & 0.462 & -0.045 \\
\hline
\end{tabular}


Vitis spp.

$-0.083$

0.378 
Table 5. Pearson correlations for each understory species with axes 1 and 2 of the NMS ordination of "smoothed" post-fire presence/absence data. UK = unknown. Exotic invasives are shown in bold.

\begin{tabular}{|c|c|c|}
\hline & $\begin{array}{c}\mathrm{R}^{2}= \\
0.790\end{array}$ & $\begin{array}{c}\mathrm{R}^{2}= \\
0.160\end{array}$ \\
\hline Species & Axis 1 & Axis 2 \\
\hline Acer pensylvanicum & 0.880 & -0.507 \\
\hline Acer rubrum var. rubrum & -0.590 & 0.017 \\
\hline Acer saccharum var. saccharum & 0.584 & -0.629 \\
\hline Adiantum pedatum & 0.362 & -0.719 \\
\hline Ageratina altissima var. altissima & 0.922 & -0.411 \\
\hline Ailanthus altissima & 0.745 & -0.348 \\
\hline Allium cernuum & 0.266 & -0.065 \\
\hline Alliaria petiolata & 0.855 & -0.555 \\
\hline Amelanchier arborea var. arborea & -0.479 & 0.822 \\
\hline Ambrosia artemisiifolia & 0.821 & -0.164 \\
\hline Amphicarpaea bracteata & 0.945 & -0.189 \\
\hline Antennaria neglecta & -0.059 & 0.902 \\
\hline Antennaria plantaginifolia & 0.169 & 0.631 \\
\hline Antennaria virginica & 0.377 & 0.476 \\
\hline Aristolochia serpentaria & 0.620 & -0.495 \\
\hline Asplenium platyneuron & 0.889 & -0.423 \\
\hline Asclepias quadrifolia & 0.824 & 0.156 \\
\hline Aster spp. & 0.326 & 0.081 \\
\hline Botrychium virginianum & 0.434 & -0.534 \\
\hline Brachyletrum erectum & 0.828 & -0.325 \\
\hline Carya alba & 0.373 & 0.637 \\
\hline Carex cephalophora & 0.835 & 0.010 \\
\hline Carex cf. pensylvanica & 0.499 & 0.479 \\
\hline Carex cf. pensylvanica/lucorum & 0.598 & -0.259 \\
\hline Carex cf. pensylvanica/lucorum/tonsa & -0.345 & -0.213 \\
\hline Campanula divaricata & 0.634 & -0.198 \\
\hline Carex digitalis & 0.056 & -0.026 \\
\hline Carya glabra & -0.710 & 0.544 \\
\hline Carex laxiflora & 0.923 & -0.383 \\
\hline Carex pensylvanica & 0.238 & 0.024 \\
\hline Carex spp. & 0.407 & -0.602 \\
\hline Ceanothus americanus & 0.478 & 0.316 \\
\hline Cf. Aureolaria laevigata & 0.511 & -0.229 \\
\hline Cf. Bromus ciliatus/Calamagrostis porteri & 0.028 & -0.408 \\
\hline Cf. Heuchera americana & 0.230 & -0.125 \\
\hline
\end{tabular}




\begin{tabular}{|c|c|c|}
\hline Cf. Hieracium spp. & 0.130 & 0.592 \\
\hline Cf. Lactuca spp. & 0.158 & -0.480 \\
\hline Cf. Lysimachia quadrifolia & -0.053 & -0.558 \\
\hline Cf. Phlox buckleyi & 0.226 & 0.520 \\
\hline Cf. Prenanthes spp. & 0.408 & -0.320 \\
\hline Cf. Scrophularia lanceolata & 0.841 & 0.080 \\
\hline Cf. Sericocarpus linifolius & 0.259 & 0.444 \\
\hline Cf. UK Asteraceae & -0.056 & 0.249 \\
\hline Chimaphila maculata & 0.060 & 0.421 \\
\hline Conopholis americana & -0.145 & -0.093 \\
\hline Cornus florida & -0.218 & -0.456 \\
\hline Corydalis flavula & 0.616 & -0.671 \\
\hline Cratageous spp. & 0.440 & 0.516 \\
\hline Cunila origanoides & 0.253 & -0.276 \\
\hline Daucus carota & 0.299 & 0.013 \\
\hline Danthonia spp. & 0.428 & -0.002 \\
\hline Danthonia spicata & -0.214 & 0.675 \\
\hline Deschampsia flexuosa & -0.160 & 0.592 \\
\hline Desmodium nudiflorum & -0.221 & -0.084 \\
\hline Dennstaedtia punctilobula & 0.682 & -0.739 \\
\hline Desmodium spp. & 0.385 & -0.625 \\
\hline Dichanthelium boscii & 0.525 & -0.105 \\
\hline Dichanthelium commutatum & -0.444 & -0.135 \\
\hline Dichanthelium depauperatum & -0.809 & 0.152 \\
\hline Dichanthelium latifolium & 0.278 & -0.391 \\
\hline Dioscorea villosa & 0.741 & -0.621 \\
\hline Dryopteris marginalis & 0.856 & -0.468 \\
\hline Draba ramosissima & 0.507 & 0.469 \\
\hline Elymus hystrix var. hystrix & 0.545 & 0.302 \\
\hline Epigaea repens & -0.840 & 0.151 \\
\hline Erigeron strigosus & 0.220 & 0.310 \\
\hline Festuca subverticillata & 0.729 & -0.416 \\
\hline Fraxinus americana & 0.470 & -0.175 \\
\hline Gaylussacia baccata & -0.878 & -0.069 \\
\hline Galium circaezans var. circaezans & 0.980 & -0.342 \\
\hline Galium lanceolatum & 0.857 & -0.295 \\
\hline Gaultheria procumbens & -0.759 & -0.188 \\
\hline Galium triflorum & 0.549 & -0.128 \\
\hline Goodyera spp. & -0.060 & -0.554 \\
\hline GRubus spp. & -0.481 & 0.291 \\
\hline Hamamelis virginiana & -0.582 & -0.505 \\
\hline Helianthus divaricatus & 0.657 & 0.293 \\
\hline Heuchera americana & 0.578 & -0.230 \\
\hline
\end{tabular}




\begin{tabular}{|c|c|c|}
\hline Hepatica nobilis var. obtusa & 0.526 & -0.412 \\
\hline Hedeoma pulegioides & 0.726 & 0.138 \\
\hline Hieracium caespitosum & -0.238 & 0.363 \\
\hline Hieracium pilosella var. pilosella & -0.548 & 0.820 \\
\hline Hieracium venosum & -0.496 & 0.313 \\
\hline Houstonia cf. longifolia & 0.438 & 0.610 \\
\hline Iris verna & -0.699 & 0.543 \\
\hline Kalmia latifolia & -0.877 & -0.032 \\
\hline Lespedeza cf. violacea & 0.294 & 0.348 \\
\hline Lespedeza hirta ssp. hirta & 0.489 & 0.372 \\
\hline Lespedeza procumbens & 0.605 & 0.365 \\
\hline Lespedeza repens & -0.481 & 0.291 \\
\hline Maianthemum racemosum ssp. racemosum & 0.101 & 0.098 \\
\hline Melampyrum lineare & -0.747 & 0.346 \\
\hline Microstegium vimineum & 0.478 & -0.584 \\
\hline Monotropa uniflora & -0.004 & -0.130 \\
\hline Nyssa sylvatica & -0.794 & -0.224 \\
\hline Ostrya virginiana var. virginiana & 0.546 & -0.619 \\
\hline Paronychia canadensis & 0.854 & -0.363 \\
\hline Paronychia fastigiata/montana & 0.320 & 0.564 \\
\hline Parietaria pensylvanica & 0.740 & -0.659 \\
\hline Parthenocissus quinquefolia & 0.689 & -0.710 \\
\hline Penstemon canescens & -0.334 & 0.653 \\
\hline Pinus pungens & -0.697 & 0.508 \\
\hline Pinus rigida & -0.831 & 0.106 \\
\hline Pinus strobus & -0.366 & 0.154 \\
\hline Pinus virginiana & -0.640 & 0.802 \\
\hline Pinus virginiana/pungens & -0.319 & -0.184 \\
\hline Polystichum acrostichoides & -0.080 & -0.615 \\
\hline Polygonatum biflorum & 0.390 & 0.665 \\
\hline Polygonum cf. convolvulus & 0.942 & -0.191 \\
\hline Poa compressa & 0.420 & 0.390 \\
\hline Polygala senega & 0.762 & -0.474 \\
\hline Potentilla simplex & -0.153 & 0.882 \\
\hline Prunus serotina & -0.011 & 0.523 \\
\hline Pteridium aquilinum & -0.749 & -0.226 \\
\hline Pycnanthemum incanum & 0.644 & -0.358 \\
\hline Quercus alba & -0.779 & 0.423 \\
\hline Quercus coccinea var. coccinea & -0.894 & 0.290 \\
\hline Quercus ilicifolia & -0.907 & 0.184 \\
\hline Quercus marilandica var. marilandica & -0.045 & 0.601 \\
\hline Quercus prinus & -0.138 & 0.400 \\
\hline Quercus velutina & -0.866 & 0.594 \\
\hline
\end{tabular}




\begin{tabular}{|c|c|c|}
\hline Rhus typhina & -0.472 & 0.287 \\
\hline Rosa carolina var. carolina & 0.101 & 0.659 \\
\hline Robinia pseudoacacia & 0.729 & 0.110 \\
\hline Rubus occidentalis & 0.318 & -0.774 \\
\hline Rubus spp. & -0.119 & -0.675 \\
\hline Sassafras albidum & -0.388 & -0.490 \\
\hline Saxifraga caroliniana & 0.947 & -0.171 \\
\hline Sedum ternatum/glaucophyllum & 0.458 & 0.553 \\
\hline Silene stellata & 0.743 & -0.107 \\
\hline Smilax rotundifolia & -0.823 & 0.169 \\
\hline Solidago caesia & 0.848 & -0.337 \\
\hline Solidago cf. nemoralis & 0.014 & 0.187 \\
\hline Spiraea betulifolia var. corymbosa & 0.126 & 0.026 \\
\hline Symphyotrichum cf. divaricatum & 0.454 & -0.376 \\
\hline Symphyotrichum divaricatum & 0.499 & 0.328 \\
\hline Symphyotrichum undulatum & 0.657 & 0.306 \\
\hline Taenidia integerrima & 0.648 & -0.048 \\
\hline Tephrosia virginiana & -0.466 & 0.487 \\
\hline Thalictrum thalictroides & 0.773 & -0.184 \\
\hline Toxicodendron radicans & 0.338 & 0.010 \\
\hline Triodanis perfoliata var. perfoliata & 0.502 & 0.463 \\
\hline UK Asteraceae & -0.089 & 0.807 \\
\hline UK Asteraceael & 0.005 & 0.515 \\
\hline UK Dicot & 0.464 & 0.207 \\
\hline UK Poaceae & -0.720 & 0.103 \\
\hline Ulmus rubra & 0.434 & -0.534 \\
\hline Uvularia perfoliata & 0.798 & -0.700 \\
\hline Uvularia puberula & -0.700 & -0.358 \\
\hline Vaccinium pallidum & -0.583 & 0.782 \\
\hline Vaccinium stamineum & -0.684 & 0.766 \\
\hline Verbascum thapsus & 0.438 & 0.431 \\
\hline Viburnum acerifolium & -0.497 & -0.420 \\
\hline Vitis aestivalis var. bicolor & 0.382 & 0.091 \\
\hline Vicia caroliniana & 0.811 & -0.236 \\
\hline Viola cf. palmata & 0.032 & 0.527 \\
\hline Viola palmata & 0.963 & -0.310 \\
\hline Viola pedata & -0.842 & 0.404 \\
\hline Vitis vulpina & -0.270 & -0.108 \\
\hline
\end{tabular}

Digitally signed by John $\mathrm{H}$. Hagen $\mathrm{DN}: \mathrm{cn}=$ John $\mathrm{H}$. Hagen, o=West 